

\title{
(IN)DIFERENÇAS EM QUESTÃO: conversando sobre diversidades
}

\author{
Edmar Reis Thiengo
}

[Organizador]

Edifes

2017 

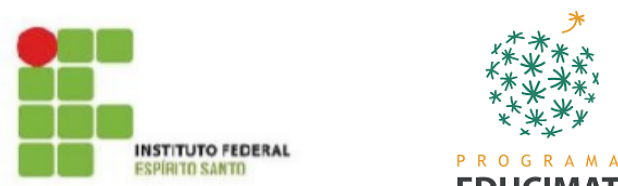

EDUCIMAT

\section{Exp? \\ Educaçāo, História e Diversidades \\ GRUPO DE PESQUISA \\ Instituto Federal do Espírito Santo}

Programa EDUCIMAT - Mestrado Profissional

Programa de Pós-Graduação em Educação em

Ciências e Matemática

Campus Vitória - Instituto Federal do Espírito Santo

Av. Vitória, 1729, Bairro Jucutuquara, Prédio Administrativo

$3^{\circ}$ andar, sala 03, Vitória, ES - CEP 29040-780

Tel (27) $3331-2203$

E-mail: educimat@ifes.edu.br

E-mail: educimat@gmail.com

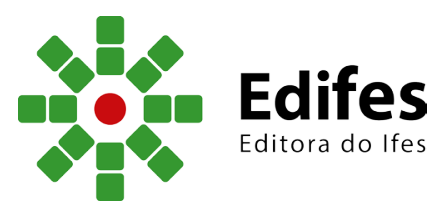

Edifes - Editora do Ifes www.edifes.ifes.edu.br

Telefone: (27) 3198-0934 / (27) 3198-0900 ramal 2130

Centro de Referência em Formação e em Educação a Distância - Cefor

Rua Barão de Mauá, 30 - Jucutuquara, - Vitória - ES CEP:29040-860 


\author{
INSTITUTO FEDERAL DO ESPÍRITO SANTO \\ PROGRAMA DE PÓS-GRADUAÇÃO EM EDUCAÇÃO EM \\ CIÊNCIAS E MATEMÁTICA
}

\title{
(IN)DIFERENÇAS EM QUESTÃO: conversando sobre diversidades
}

\author{
Edmar Reis Thiengo
}

[Organizador]

\author{
Colaboradores: \\ Allana C. B. Resende \\ Ana Paula Brasil \\ Antônio Lopes de Souza Neto \\ Brenda Onofre Pfeifer de Araújo \\ Flavio Lopes dos Santos \\ Guilherme Augusto Marciel Ribeiro \\ Haroldo Júnior Evangelista Vidal \\ Janivaldo Pacheco Cordeiro \\ Nahun Thiaghor Lippaus Pires Gonçalves \\ Robson Wilson Carneiro Onofre \\ Robson Vinícius Cordeiro \\ Steferson Zanoni Roseiro \\ Thamires Belo de Jesus \\ Vagner Lorenção
}

\section{VITÓRIA}




\section{FICHA CATALOGRÁFICA}

Dados Internacionais de Catalogação na Publicação

Bibliotecária Rossanna dos Santos Santana Rubim-CRB6- ES 403

I39 (In)diferenças em questão : conversando sobre diversidades / organizado por Edmar Reis Thiengo. - Vitória, ES: Edifes, 2017.

164 p. : il.

Vários autores.

ISBN: 9788582632024 (e-book).

1. Educação - Multiculturalismo. 2. Pluralismo cultural. I. Thiengo, Edmar Reis. II. Título.

CDD $22-370.117$

DOI: $10.36524 / 9788582632024$

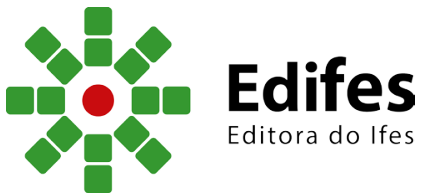




\section{Revisão de texto:}

Janivaldo Cordeiro Pacheco

Edmar Reis Thiengo

Flávio Lopes dos Santos

Normalização técnica:

Edmar Reis Thiengo

Flávio Lopes dos Santos

\section{Comitê Científico:}

Alex Jordane - IFES

Antônio Donizetti Sgarbi - IFES

Carlos Roberto Pires Campos - IFES

Eduardo Augusto Moscon Oliveira - UFES

Helio Roseti Junior - IFES

Hellen Castro de Almeida Leite - UFES

Manuella Villa Amado - IFES

Sidnei Quezada Meireles Leite - IFES

Priscila de Souza Chisté Leite - IFES

\section{Coordenação Editorial:}

Edmar Reis Thiengo

\section{Capa:}

Wendel Alexandre Albino Macedo

Projeto Gráfico e Editoração Eletrônica

Flávio Lopes dos Santos

\section{Produção e Divulgação:}

Programa de Pós-Graduação em Educação em

Ciências e Matemática (EDUCIMAT)

Av. Vitória, 1729, Bairro Jucutuquara, Vitória, ES - Editora: IFES

Tel. (27) 3331-2203

E-mail: educimat@ifes.edu.br

E-mail: educimat@gmail.com 


\section{EXPEDIENTE}

Denio Rebello Arantes

\section{Reitor}

Araceli Verónica Flores Nardy Ribeiro

Pró-Reitora de Ensino

Renato Tannure Rotta de Almeida

Pró-Reitor de Extensão

Marcio Almeida Có

Pró-Reitor de Pesquisa e Pós-graduação

José Lezir Ferreira

Pró-Reitor de Administração e Orçamento

Ademar Manoel Stange

Pró-Reitor de Desenvolvimento Institucional

Ricardo Paiva

Diretor Geral do Campus Vitória

Vanessa Battestin Nunes

Diretora de Educação a Distância/Cefor

Programa de Pós-graduação em Educação em Ciências e Matemática

Sidnei Quezada Meireles Leite

Coordenador

Alex Jordane de Oliveira

Vice-Coordenador

Vitória, Espírito Santo 2016 


\section{PREFÁCIO}

Este livro é o resultado de processos de reflexão, debate e trabalho de diferentes autores/pesquisadores, oriundos do grupo de pesquisa "Educação matemática, diversidade e inclusão" que tem um comprometimento e envolvimento com as questões pertinentes à área da educação e com a produção de novos/outros conhecimentos, na perspectiva da educação inclusiva. Nesse sentido, os autores propõem problematizar as relações presentes no contexto da escola e da sociedade baseadas no padrão hegemônico da sociedade brasileira, "heteronormativo", que (re) produz a discriminação, o preconceito, o estereótipo e a exclusão de diferentes sujeitos histórico-sociais nos diferentes espaços sociais, entre estes o da escola.

Atentos ao contexto histórico e político de mudanças na/ da educação, especialmente, marcado pelas diferentes políticas educacionais que tratam de direitos sociais destinados aos sujeitos que historicamente foram excluídos dos processos de escolarização, os autores estabelecem o diálogo entre a(s) diversidade(s) e a educação, nos possibilitando reflexões e quiçá mudanças nas concepções e práticas acerca das diversidades e dos diferentes sujeitos presentes na escola e na sociedade.

Diversidade(s) talvez seja a palavra e/ou conceito que sintetiza as diversas temáticas trabalhadas nesse livro: diversidade(s) religiosa, cultural, étnica, linguística e sexual. Os textos apresentados de maneira teórica, crítica e sensível conseguem nos deliciar não apenas com variedade e complexidade de facetas que 
envolvem essas temáticas, mas também pelas implicações dos conhecimentos ali constituídos.

No livro, apreciamos o incessante esforço dos autores em tratar de temáticas de extrema relevância e, ao mesmo, temáticas historicamente silenciadas e invisibilizadas nas produções acadêmicas e no contexto das instituições escolares.

Noprimeiroartigo, osautoresnosbrindamcomodebateacerca das temáticas de sexualidade, gênero e suas performatividades a partir de uma análise de um seriado estadunidense que aborda o cotidiano de um sujeito trans para/no cotidiano da sociedade moderna. Nesse sentido, o texto nos faz refletir sobre as novas formas de existência e múltiplas possibilidades de representação da sexualidade de sujeitos(as), com diferentes modos de ser/estar no mundo. Além disso, nos possibilita refletir acerca dos conflitos vivenciados pelos adolescentes e jovens no contexto escolar e que estão distantes dos currículos escolares. Assim como, nos faz pensar nas políticas instituídas ou não para os sujeitos trans e nos discursos que invisibilizam e excluem sujeitos desviantes e marginalizados pela norma vigente.

No segundo artigo os autores trazem à tona as problemáticas que atravessam os sujeitos e o cotidiano da escola, a partir de um diálogo com um apresentação artística de dança, que abordou o quanto a sociedade - as escolas - por meio dos seus discursos e práticas únicas, hegemônicas e normativas aprisionam os sujeitos, sem considerar as diferenças presentes no cotidiano e currículo escolar; ou seja, os diferentes modos dos aprendentes que rejeitam os modelos clássicos de atuação docente e conciliam 
conflitos para criarem mais diferenças, ao invés de reduzi-las.

No terceiro artigo, os autores trazem contribuições importantes para refletir sobre o padrão heteronormativo da escola ao lidar com os campos da sexualidade e de gênero. Nessa perspectiva, destacam que a escola enquanto espaço social e dialógico contribui para a construção ou reconstrução de normais e regras sociais, desse modo, pode promover a desigualdade e a exclusão e/ou constituir outras relações mais democráticas na escola. Ressaltam a exclusão e invisibilização dos homossexuais no espaço escolar, ampliando a homofobia e a opressão às minorias, estabelecendo a heteronormatividade como padrão moral socialmente valorizado. Além disso, enfatizam os altos índices e relatos sobre a violência contra a mulher e a população LGBT no Brasil, mostrando a necessidade de ampliação dessas temáticas na escola. Nesse contexto, os autores desenvolvem uma pesquisa em uma escola de educação básica, de modo a compreender como as meninas lésbicas se percebiam no ambiente escolar e como se relacionavam com os docentes, demais servidores e seus pares. Relações marcadas por exclusão e discriminação. Ao final falam da importância da formação de educadores para questão da diversidade e inclusão com vistas à equalização do tratamento dedicado a pessoas de identidade de gênero e orientações sexuais diversas.

No quarto artigo, os autores nos possibilitam reflexões sobre a regulação social da sexualidade, sua visibilidade e não silenciamento nos ambientes escolares. Enfatizam que a sexualidade é construída historicamente pela cultura, em determinado espaço de tempo, nas relações socialmente estabelecidas. Consideram 
que as concepções sobre o corpo são reproduzidas nas relações e processos concebidos na escola que, por sua vez, apresenta práticas que desprestigiam e invisibilizam as diversidades sexuais e de gênero existentes no cotidiano escolar. Nesse contexto, desenvolvem um estudo da percepção dos alunos e funcionários de uma instituição de ensino, a partir da inserção de um "corpo estranho" nesse ambiente formal de ensino. Ao final, ressaltam a manutenção das relações de gênero vigentes e regulações sociais de sexualidade institucionalizadas nos espaços escolares, reforçando as divisões sexuais e os comportamentos a serem assumidos por homens e mulheres. " $\mathrm{O}$ 'corpo estranho' sofre com sansões de sua liberdade: o preconceito, explícito ou velado".

No quinto artigo os autores realizam uma análise acerca da diversidade religiosa na escola sob a perspectiva inclusiva tomando como referência os aspectos históricos e sociais, os aspectos legais e os direcionamentos curriculares para o trato pedagógico. Além disso, refletem sobre a configuração das abordagens e controvérsias acerca do ensino religioso e as possibilidades de tonar a disciplina um espaço tempo de debate sobre à diversidade de crença, pensamento e de expressão, numa perspectiva inclusiva. Nesse sentido, realizam uma análise dos planos de ensino anual no ensino fundamental que discutem as potencialidades que subjaz a disciplina para o desenvolvimento de práticas inclusivas num contexto escolar, pautadas no reconhecimento da diversidade em suas múltiplas configurações, e o respeito ao sujeito independente das características físicas, da maneira de pensar e da fé professada ou não. Nesse contexto, os autores propõem cinco 
compreensões sintéticas e sugestões para uma prática pedagógica inclusiva, a saber: distanciamento de modelos catequizadores; compreensão da multiplicidade de entendimentos do fenômeno religioso; embasamento em práticas respeitosas e no reconhecimento da diversidade; não omissão das incongruências religiosas; e rejeição, reflexiva, da necessidade incontestável da religião para a vida humana.

No sexto artigo os autores discutem a importância da temática da sexualidade infantil nas séries iniciais do ensino fundamental como forma de promoção do conhecimento de si mesmo, de sua relação com o outro e, portanto, da sua sexualidade. Para tanto, debatem o tema à luz de estudiosos e pesquisadores da área, em consonância com os Parâmetros Curriculares Nacionais, propondo ações e reflexões que apoiem os educadores no desenvolvimento de seu trabalho.

O sétimo artigo discute a temática de diversidade sexual no espaço escolar, a partir de uma relato de uma dinâmica pedagógica intitulada "Roda de Conversa" realizada na disciplina "Diversidade e Inclusão Social em Educação em Ciências e Matemática", no curso de mestrado do Programa de Pós-graduação em Educação em Ciências e Matemática (EDUCIMAT) do Instituto Federal do Espírito Santo (IFES), ofertado no Campus Vitória. Os autores apontam as observações e reflexões de professores e convidados quanto à temática da diversidade sexual como forma de contribuir para formação dos profissionais, suas ações e opiniões no contexto escolar e social a partir da dinâmica desenvolvida nesta disciplina. A partir da realização da dinâmica, os autores puderam 
constatar que constatar o quanto o assunto da diversidade sexual é pouco tratado no espaço escolar, sobretudo na formação inicial e continuada dos profissionais da educação. Ainda que a temática esteja presente nos Parâmetros Curriculares Nacionais (BRASIL, 1998) como tema transversal, verifica-se um distanciamento muito grande com a prática cotidiana.

Cumpre destacar que este livro revela os preconceitos, os estereótipos e a discriminação existentes nas relações estabelecidas entre os sujeitos: alunos, professores, servidores e comunidade em geral, no cotidiano da escola e que estão sedimentados baseadas nas relações constituídas histórico e socialmente que legitimam a preterição de pessoas, grupos pelas suas diferenças religiosas, crenças, preferências sexuais e singularidades.

Os conhecimentos produzidos nesse livro, nos levam a pensar sobre a importância de conceber a escola como espaço da diversidade, em que as diferenças não se constituam em desigualdades e/ou exclusão. Além disso, nos faz refletir sobre a importância da formação continuada para os professores e servidores que atuam na escola, com vistas a construir novos/outros paradigmas que rompam com preconceitos e concepções enraizadas no pensamento e nas ações voltados aos sujeitos(as) de identidade de gênero, orientações sexuais e religiosa diversas. Ademais, nos levam a outras/tantas questões/reflexões: como tem sido trabalhado essas temáticas no contexto da escola e na formação de professores? As práticas educativas instituídas tem conseguido atender aos distintos percursos de ensino e aprendizagem dos diferentes sujeitos no âmbito escolar? 
Na tentativa de adensar a discussão, sobre temáticas carregadas de sentidos, significados e complexidades, deleitemo-nos com a leitura deste belo e instigante trabalho, fruto de uma nova e criativa geração de pesquisados da área de educação.

Marileide Gonçalves França Professora/Pedagoga do Instituto Federal do Espírito Santo Doutora em Educação 
(IN)DIFERENÇAS EM QUESTÃO: conversando sobre diversidades

\section{SUMÁRIO}

CONVERSANDO SOBRE DIVERSIDADE 16

1 - OUTROS TEMPOS, MAIS EMOÇÕES, BRILHOS INTENSOS: DE Grease À GleE, DA BRILHANTINA AO GLITER 19

2 - DE SAPATILHAS OU SAPATÕES: O PALCO DAS ATRIZES CONTRATADAS POR ENGANO

3 - CORPOS QUE PROVOCAM O IMAGINÁRIO CONSERVADOR:

LÉSBICAS NA ESCOLA 68

4 - O CORPO ESTRANHO NA ESCOLA: CONSIDERAÇÕES SOBRE A REGULAÇÃO DA SEXUALIDADE NO CONTEXTO ESCOLAR .81

5 - EDUCAÇÃO E DIVERSIDADE RELIGIOSA: POR UM AMBIENTE RESPEITOSO E DIALÉTICO 98

6 - EDUCAÇÃO INFANTIL E SEXUALIDADE: SUPERANDO PRECONCEITOS. 125

7 - JOSÉ-MARIA-JOSÉ: DISCUSSÕES ALÉM DO SEXYO BIOLÓGICO. 142 


\section{CONVERSANDO SOBRE DIVERSIDADE}

Se cada ser é só um

E cada um com sua crença

Tudo é raro, nada é comum

Diversidade é a sentença

Lenine

Embora seja um substantivo feminino, o termo diversidade caracteriza o que é diverso, que tem multiplicidade, sendo uma reunião de tudo aquilo que apresenta múltiplos aspectos e que se diferenciam entre si. Engloba, portanto, o masculino, o feminino e o plural. Assim observado, pode-se dizer que há uma diversidade humana que se percebe pela diversidade religiosa, diversidade cultural, diversidade étnica, diversidade sexual, diversidade linguística, e mais uma diversidade de diversidades. Para Gurgel, a ideia de diversidade está intimamente ligada à pluralidade, multiplicidade, heterogeneidade e variedade.

Assunto cada vez mais presente nos debates em diferentes ambientes, nos espaços educacionais tem se intensificado e acalorado; no entanto, ainda carece de práticas mais amplas sobre a temática, de diálogos mais próximos ao professor e à escola.

A diversidade de pensamentos produz um debate saudável, proporcionando reflexões importantes e salutares, desde que respeitadas as diferenças. Caso contrário, retorna-se à velha prática 
de descartar aquilo que é diferente do que pensamos e concebemos como possível.

Assim, estabelecer o diálogo entre as diversidades e a educação é um exercício necessário para estabelecer e elaborar novas práticas e promover mudanças paradigmáticas em nossa sociedade, ainda muito conservadora.

Nesse processo, cada pessoa é de fato um ser único e traz consigo uma gama de possibilidades que se revelam em seu jeito peculiar de ser. Traz uma bagagem cultural, um jeito próprio de ser, perspectivas e possibilidades que são muito particulares e precisam ser consideradas.

Ao pensar em tais pressupostos, apresentamos a seguir um conjunto de textos que dialogam com as diversidades de forma ampla, em uma perspectiva abrangente e sem fronteiras, na busca por uma identificação com os sujeitos como são e não como gostaríamos que fossem.

A Unesco divulgou no ano de 1972 o relatório Faure, em que discutia os fundamentos da chamada nova educação, destacando a importância de preparar o indivíduo para elaborar ao longo da vida um saber em constante evolução, na perspectiva do aprender a ser (FAURE, 1972), não cabendo mais a imposição de conhecimentos prontos, o que dificulta a formação desse indivíduo. Em 1996, ampliando essa perspectiva, a UNESCO publicou o relatório Delors, em que valoriza o aprender a conhecer, aprender a fazer, aprender a conviver e o aprender a ser, sendo estes os quatro pilares da educação para o século XXI.

Considerando que a educação deve se direcionar na busca 
por uma formação holística do ser, as diversidades precisam não apenas ser respeitadas, mas divulgadas e ampliadas, devendo ser percebidas como natural e importante, independente da análise feita: seja no ponto de vista cultural, religioso, sexual, étnico etc.

Nessa perspectiva e linha de pensamento, um grupo de educadores, atentos às desigualdades sociais e ao desrespeito às diferenças existentes hoje na sociedade, reuniu-se para dialogar e debater temas que foram surgindo em função de demandas, formando-se assim o grupo de pesquisa Educação Matemática, Diversidades e Inclusão.

Esta obra, tecida no interior do grupo de estudos, apresenta importante material que coloca em destaque algumas das questões que foram objeto de discussões no grupo, e compartilha com os leitores os resultados iniciais de tais discussões. Cada artigo é resultado do esforço de um pesquisador, e o leitor poderá perceber um pouco de cada um, seus olhares e vivências, bem como a preocupação em colaborar com o debate proposto.

Sugerimos uma leitura criteriosa, embora com a certeza de que será realizada com muito prazer!

Deleite-se!

Edmar Reis Thiengo

Organizador 
OUTROS TEMPOS, MAIS EMOÇÕES, BRILHOS INTENSOS: DE GREASE À GLEE, DA BRILHANTINA

AO GLITER

Robson Wilson Carneiro Onofre Allana Cristini Borges de Resende Janivaldo Pacheco Cordeiro Edmar Reis Thiengo

Ah, que ninguém me dê piedosas intenções,

Ninguém me peça definições!

Ninguém me diga: "vem por aqui"!

A minha vida é um vendaval que se soltou,

É uma onda que se alevantou,

É um átomo a mais que se animou...

Não sei por onde vou,

Não sei para onde vou

Sei que não vou por aí!

José Régio

Podem as inquietações de um personagem de um seriado estadunidense, Glee, nos provocar e trazer à tona discussões a respeito de uma temática tão delicada: o cotidiano de um sujeito trans, para/no cotidiano da sociedade moderna? Até que ponto o autor, Ryan Murphy ${ }^{1}$, consegue delinear no seriado uma discussão abrangente e idônea sobre os conflitos desse sujeito/personagem enquanto abjeção social?

Para iniciar a discussão destes questionamentos que faze-

1 Ryan Murphy é um escritor, jornalista e produtor de cinema e televisão estadunidense, mais conhecido por criar e escrever as séries Nip/Tuck e a comédia-drama musical Glee. 
mos, recorremos à Pinel, que disserta a respeito dos propósitos pedagógicos presentes nas performances e subjetivações das personas fictícias presentes nas narrativas dos filmes/seriados.

O cinema é antes de tudo entretenimento, e nem sempre tem o objetivo explícito de ensinar. Há aquelas obras que são antes de tudo educativas $[\ldots]$

Por outro lado, existem aquelas obras de artes que sutilmente nos ensinam Política e modos de fazer oposição do estabelecido e isso pode ser apreendido [...] (PINEL, 2013, p. 25).

Para Pinel (2013), uma obra de arte pode ser um dispositivo provocador, então! Provoca nossa dor de descobrirmos "modos de ser sendo junto ao outro no mundo" ou "modos de ser sendo"... (PINEL, 2013, p. 26).

Pinel afirma que ainda que não possua a intencionalidade de ensino e aprendizagem para alguns espectadores, uma obra de arte possibilita reflexões, análises e interpretações diversas.

A ficção é levada ao real e nos faz suportar essa experiência denominada "é isso mesmo meu companheiro o que estás vivendo!”. A vida nem sempre é cinema, é real e pode virar cinema, e quem sabe obra de arte. (PINEL, 2013 p. 26)

\footnotetext{
A ficção deve/pode nos levar a "reviver" imagensnarrativas $^{2}$ dos personagens, e com elas experimentar, de forma similar, as aflições/tensões/humilhações/subserviência que por eles são

2 O uso de palavras agrupadas desta forma é utilizada por muitos cotidianistas, como Nilda Alves e Carlos Eduardo Ferraço, para atribuir um novo sentido e ressaltar que estes processos acontecem juntos, dependentes, entrelaçados.
} 
vividas. Esses "modos de ser junto ao outro no mundo", assinalados por Pinel (2013), nos remetem às afetações dessas personagens que nos atingem, nos comovem, nos sensibilizam. É também essa sensibilização que nos leva a querer que os excluídos tenham voz e a repensar discursos que reiterem a norma vigente e marginalizadora.

As reflexões que podemos fazer ao analisar as imagensnarrativas de Wade Adams, personagem interpretado por Alex Newell, no seriado Glee, nos remetem a representações que são de extremo antagonismo. Wade Adams é representado pelo autor como um adolescente, que como muitos outros, está em conflito. Soma-se a essa desordem, inerente à idade, a própria "batalha" vivida por Wade: seu comportamento travesti. Tomaz Tadeu Silva delineia com muita propriedade essa matiz de cores que, mesmo que provisoriamente, não está contido/aprisionado apenas nos aspectos discursivos, mas também nos "discursos" performativos.

[...] Com a introdução do conceito de "performatividade", a teórica queer Judith Butler quer enfatizar o fato de que a definição da identidade sexual não fica contida pelos processos discursivos que buscam fixá-la. Nessa concepção, mesmo que provisoriamente, mesmo que precariamente, nós somos aquilo que nossa suposta identidade define que somos (SILVA, 2004, p. 107)

Ao analisar o comportamento de Wade, durante o seu episódio de estreia, Os Glee-Embalos de sábado à noite, podemos inferir um devir-travesti, no qual à medida que as micropolíticas 
que sua subjetividade vierem a representá-lo, surgirão formas de captura, representadas pela heteronormatividade, para aprisioná-la. Confinando-a dentro do binarismo norma/abjeção que rearfima a norma.

Dallapiculla (2014) analisa os mecanismos de reafirmação da heteronormatividade, e salienta que a negação desta, ratifica-a. A reafirmação a produz. Todas as expressões de uma identidade se configuram em estruturas políticas de captura do sujeito desviante. Pois ao sinalizar a expressão de sua identidade, o "diferente" toma como parâmetro a norma; que não se explica, posto nesse compasso de afirmação identitária como "natural".

Porém, se entendemos que para haver poder deve haver, antes dele, a resistência, passamos a pensar que as sexualidades "desviantes", as representações não formatadas do feminino, são condição sine qua non para a produção enunciativa dos binarismos de gêneros e sexualidades. É a tentativa de controle do desviante que produz a norma (DALLAPICULA, 2014, p. 44).

Segundo Foucault (2013) o Estado formula determinações de condutas sexuais, no limite entre o biológico e o econômico. Para o autor são produzidas campanhas sistemáticas à margem das exortações morais e religiosas, propondo fazer do comportamento sexual conduta política e política deliberada. Entre o Estado e o indivíduo, o sexo tornou-se objeto de disputa, disputa pública, produzindo toda uma teia de discursos, de saberes, de análise e de injunções que o investiram. 
Inúmeras táticas de produção de si são utilizadas pelas participantes na negociação com seus corpus materiais, com características desejáveis e admiráveis, ou não para aproximarem-se do esperado [...]Percebemos assim, que o dentro e o fora também são produzidos neste lócus de enunciação, como pedagogia pública da sexualidade feminina, utilizando o corpo como instância da impossibilidade de existência e resistência (DALLAPICULA, 2014, p. 49).

Nesse processo de transformação, o corpo passa por mudanças possíveis, no intuito de atender aos parâmetros de gênero pré-estabelecidos pela norma vigente. Dallapicula (2014) analisa que se o corpo não "cabe" nas normas, não permite existir, apenas resistir nesse contexto.

Para Wade seu corpo é sua maior arma para resistência a todas as formas de humilhação ao qual está sujeito, mas modificar seu corpo para identificar-se travesti, ou seja; salientar uma identidade é uma forma de captura e reafirmação do hegemônico, pela existência da diferença. Sua existência, enquanto personagem é por si só uma representação política das abjeções presentes nesse cotidiano, pois produzem discursos de novas possibilidades de vida e de corpo que "torcem" a norma (DALLAPICULA, 2014).

$\mathrm{O}$ adolescente (enquanto Wade Adams) é retratado na série como um garoto introspectivo, temeroso, acuado e capaz de suportar as mais diversas humilhações e tentativas de subalternização. Por quê? Wade é um garoto do gênero masculino - que não o identifica, segundo suas palavras. Sua subalternização é reflexo da insegurança que o assola a cada momento que habita um cor- 
po, de gênero que não the cabe, não the basta e não representa suas performances.

Rodrigues (2014) corrobora com a idéia de que as narrativas que são contadas sobre si e sobre suas afeições com os outros, apresentam as micropolíticas das relações de poder, de resistência e de sobrevivência. As histórias que por esses sujeitos são contadas nos remetem a desejos de fazer uma escuta sensível.

[...] para além das narrativas e histórias de sofrimento, tristeza, tragédia e adoecimento, é possível narrar e apostar em outras histórias, uma vez que elas são possíveis de acontecer, serem ouvidas e problematizadas (RODRIGUES, 2014, p. 25)

[...] o corpo se tornou ao longo dos anos um espaço de investimento político capaz de produzir tipos de sujeitos específicos para determinados desejos criados nas relações de poder. Muito mais do que os espaços institucionalizados, como a escola, as prisões, os manicômios, os conventos, os hospitais, entre outros, o espaço do corpo também é (re)cortado nas micropolíticas e nos mais variados espaços onde o poder se ramifica e se faz acontecer (FOUCUALT apud RODRIGUES, 2014, p. 26)

Na contramão do perfil desse adolescente subjugado, à margem de toda e qualquer classe social instaurada dentro do espaçotempo de uma escola de ensino médio, existe o alterego de Wade: Unique. Unique como seu próprio nome denota é uma personagem ÚNICA ${ }^{3}$ dentro da série, assim como é única na vida e nas performances de Wade. Em alguns momentos e narrativas apresentadas na série fica claro que Unique é a personificação/

3 A palavra foi escrita em caixa alta com o propósito de que o leitor perceba como a personalidade de Unique é capaz de ocupar o espaço da cena, e dessa forma ser única. 
materialização da subjetividade que Wade deseja externar, já que lhe garante proteção física e psíquica dos constantes ataques que eleela ${ }^{4}$ sofre.

[...] sendo constituídas por fatores sociais, políticos e culturais e sendo elemento constituinte das identidades, a homossexualidade, ou melhor, as identidades sexuais e sexualidades só podem ser percebidas pela consideração da dimensão moral presente na construção social e histórica da sexualidade (BUSSINGER, 2013, p. 129).

Bussinger (2013) traz à luz o que de fato pesa contra as subjetividades das ações corpóreas de Wade/Unique ${ }^{5}$. EleEla é a materialização do desviante. Porém esse julgamento, esse pré-conceito, é datado, na medida que a abjeção social é uma construção determinada no espaçotempo, e dessa forma parametrizada em relação a norma vigente nessa cultura.

Para Lima (2014, p. 202) o pensar sobre novas formas de existências, e assim incluímos a existência de um personagem fictício, tem poder para promover um debate necessário sobre as múltiplas possibilidades de representação da sexualidade dos sujeitossujeitas, sendo essa condição de sua existência.

[...] os corpos passam por diferentes técnicas de treinamento (andar, pescar, dormir, nadar, desfilar, etc..) e que estas técnicas estavam circunscritas aos diferentes domínios culturais. Desde então, no

4 Os pronomes pessoais que identificam os gêneros foram escritos com essa construção para traduzir a impossibilidade de realizar, em determinados momentos do episódio, distinção do gênero da personagem

$5 \mathrm{O}$ nome da personagem foi dessa forma escrito por não podermos realizar distinção do gênero que está representado na cena, e também para frisar o "trânsito" que vive a mesma. 
campo das designadas ciências do social, o corpo não é tomado enquanto um dado natural e não se encerra em sua dimensão biológica, mas constitui uma complexidade mutável, flexível, plural, polimorfa e polissêmica (LIMA, 2014, p. 203-204).

A personagem Unique nos remonta a ideia central presente nos alteregos de super-heróis, porém ao contrário. Os superheróis durante a maior parte do tempo são pessoas comuns, mas em ocasiões especiais, quando há situações de grande necessidade e/ou perigos para uma dada sociedade, o alterego toma conta da personalidade. $\mathrm{O}$ super-herói assume a personalidade nesses contextos, porque são poderosos, destemidos e ousados. Todavia em todas as personificações de super-heróis está presente nas narrativas a intensa vontade desses em serem nada mais que seres humanos comuns.

Os super-heróis desejam ser seres humanos comuns, por assim estarem dentro da norma. Nem mais, nem menos. Como todos. Aceitos como iguais. Ou seja, super-heróis desejam ser menos. Ser como todos. Wade ao contrário deseja que seu alterego, Unique, domine sua personalidade. O que possui Unique que faz com que Wade abra mão de suas representações/performances em favor de Unique?

A inclusão é um imperativo da sociedade contemporânea. Ela é uma estratégia que está implicada diretamente na nova ordem social neoliberal e sua decorrente fragmentação social. Nessa nova ordem, criam-se as condições de possibilidade para o gerenciamento dos sujeitos, tornando-os autônomos e empresários de si mesmos [...] (SANTOS, 2013, p. 62). 
O imperativo de inclusão, para poder ser gerenciador de si próprio também é problemática permanente para Wade, pois não possui voz. É um garoto acuado, que possui medo de ser/estar. A feminilidade do corpo de Wade não o permite serestar em igualdade, pois não o é, mas esses marcadores sociais são essenciais para construir Unique.

[...] apresentam diversos dispositivos enunciativos a que recorrem para produzir-se enquanto mulheres na construção de suas personas. Esses marcadores, que refletem-se às convenções sociais de performance de gênero, constituem-se como dispositivos na construção do corpo e afirmação do eu feminino perante as performances a ele reservadas (DALLAPICULA, 2014, p. 42).

Dallapicula evidencia o quanto alguns dispositivos, enquanto dispositivos de construção social dos gêneros podem ser evidenciados como produtores do eu feminino. O é também para Wade/Unique, para permitir que Unique domine a personalidade não basta ser ele/ela, é preciso estar ele/ela. São precisos artifícios e dispositivos que enunciem a transformação em algo que não é Wade.

Unique possui a coragem e inclui Wade em um contexto social em que as performances e marcadores de gênero são de extrema relevância: o ensino médio. $\mathrm{O}$ adolescente busca identidades, e muito por isso não compreenda o transitório. Unique é para Wade uma identidade que lhe cabe como um lindo vestido. Ela dá a si a possibilidade de tomar as próprias decisões 
e de fazer parte de um contexto com voz, percebida, notada, importante, única.

Unique é o que Wade sonha em ser. Unique é confiante. É vista, percebida. É notada. É respeitada. Unique tem toda atenção e coragem que Wade nem em seus melhores momentos teria. Unique tem a coragem para ser quem é. Tem iniciativa para fazer o que Wade gostaria de fazer, e principalmente, Unique eleva Wade à categoria de humano. Sem Unique, Wade está em uma categoria subumana. Menos que um humano.

[...] uma história ficcional que se assemelha a algumas realidades sociais, culturais, virtuais, curriculares, sexuais, raciais e religiosas por muito de nós conhecidas nos campos de exclusões sociais e culturais produzidas em diferentes temposespaços, com discursos de verdade que se convencionou chamar por modernidade e pela monocultura. Exclusões que "não ousamos dizer o nome" (RODRIGUES, 2013, p. 70).

A existência de Wade/Unique dentro da série é um contraponto à heteronormatividade, um devir-travesti ou um devir-trans. A existência do transtorno de identidade de gênero de Wade traz à luz esses excluídos, dentro de uma série em que o protagonismo é exclusivamente de excluídos. Todavia, mesmo dentro de uma série que trata da existência das multilpicidades de ser/estar no mundo, Wade/Unique tenta encontrar um gênero que o defina, sem compreender que a sua existência já demarca sua subjetividade, sua própria performance de gênero.

[...] o corpo se torna importante espaço de (re)in- 
venção e inovação na experiência de si. É o corpo se esvaziando e se preenchendo com uma série de dispositivos e mecanismos disponíveis e revolucionantes. É o corpo, no seu, limite, que torna um ser intenso, um nódulo onde tantas outras coisas, fatores, processos se ramificam e se conectam na produção da escrita(s) de si (DELEUZE E GUATTARI, 1997 apud RODRIGUES, 2014, p. 26).

O início da narrativa do episódio em que Wade/Unique aparece nos permite delinear basicamente o perfil da personagem. Wade busca aconselhamento, mas relata quase ter se autoimpedido pela própria inércia, pelos seus medos já interiorizados. A inércia de Wade foi autogerada, porém infligida à medida que suas performances foram constantemente apontadas como fora do padrão. Com as constantes repreensões que Wade deve ter sofrido ao longo de sua vida, possivelmente passa compreender que seu corpo e as narrativasimagens que esse é capaz de criar, não são bem-vindas.

Nos últimos anos, o que percebemos é uma escola que, em função da insistente pauta dos direitos humanos, começa a diminuir o discurso homofóbico explícito; porém, ele se amplia de forma velada, ficando implícito aquilo que não foi expressamente dito (FILHO, 2013, p. 189).

Wade se ressente de ser quem é não pelo que lhe é dito diretamente, mas sim pelos discursos indiretos que remontam toda uma estrutura de escárnio e desprezo. Wade no dia a dia da escola se adapta à norma. É um garoto como todos. Vestese de forma "adequada", mesmo se identificando com o gênero 
feminino e todos os dispositivos de construção desse gênero. Mas não revela seu verdadeiro eu em todos os espaços da escola. Unique só existe nos espaços seguros da escola: na sala de coral ou nas apresentações do grupo Vocal Adrenaline.

A escola tornou-se um espaço em que rotineiramente circulam preconceitos que colocam em movimento discriminações de diversas ordens: classismo, racismo, sexismo, heterossexismo, homofobia e outras formas de gestão das fronteiras da normalidade fazem parte da cotidianidade escolar. Não são elementos intrusos e sorrateiros, que além de terem entrada franca, agem como elementos estruturantes do espaço escolar, onde são cotidiana e sistematicamente consentidos, cultivados e ensinados, produzindo efeitos sobre todos/ as (JUNQUEIRA, 2014, p. 101).

Wade é rechaçado. Unique é ovacionada. Wade não possui amigos. Uniuqe é uma estrela. Cada exclusão social que Wade sofre, faz com que Unique ganhe mais espaço para assumir o papel central da personalidade Wade/Unique.

Pinel (2014) exemplifica essas múltiplas sensações vividas por esta personagem tão intrigante. Para o autor a construção das subjetividades e performances dos sujeitos são produzidas, modeladas em tramas constitutivas de poder. Dessa forma, podemos compreender o quanto no imaginário de Wade/Unique a ideia coletiva, e amplamente difundida, que ele/ela a seu nicho social fazem dele/dela, ganha contornos de verdade absoluta. Por isso Unique é tão importante na vida dessa personagem, pois ela é força, entusiasmo, coragem, fluidez e principalmente adequação 
à norma vigente. Unique é poder/ser.

[...] mais uma vez com o auxílio dos estudos de Foucault (1985), trata-se exatamente de uma relação, um jogo, uma aposta em que todos os envolvidos estão fazendo parte desse processo: o poder (ou seja, os discursos, os currículos, os saberes e os modos de vida) não pode ser entendido como algo que poucos têm/possuem em detrimento de outros, mas como uma trama em rede que se faz de forma coletiva (RODRIGUES, 2014, p. 2223).

Assim, Para Rodrigues (2014) essa rede nunca está esgotada, mas em construção e sempre será (re)direcionado, ao longo dos processos históricos, sociais e culturais.

$\mathrm{Na}$ busca de trazer tais confiltos, analisaremos duas cenas que julgamos importantes para o desenvolvimento de nossas reflexões.

\section{CENA 1:}

\section{CORREDOR DO COLÉGIO MCKINLEY HIGH} SCHOOL

Wade: Kurt Hummel? Mercedes Jones?

W: Desculpe interromper, mas sou seu maior fã.

W: Fui a todos os seus shows, exceto Amor Sublime Amor. Boicotei aquele porque vocês não foram Tony e Maria.

Kurt: Puxa, olá, senhor gentil. Acho que não peguei seu nome.

W: Wade Adams. Sou da Carmel High. E estou no Vocal Adrenaline e sei que devíamos ser arqui-inimigos, mas juro que 
não sou espião. Quero conselho sobre um negócio.

Nosso treinador é Jesse St. James.

\section{SALA DE ENSAIOS DO VOCAL ADRENALINE}

Jesse St. James: A estrela do Vocal Adrenaline é o Vocal Adrenaline. Ninguém é especial. É o grupo. Se não gostarem, a porta da rua está ali.

Entendeu, Chunks McGriddle?

W: Sim, senhor.

J: EU NÃO OUVI VOCÊ!

W: Sim, senhor.

\section{CORREDOR DO COLÉGIO MCKINLEY HIGH SCHOOL}

Mercedes Jones: Ele é horrível!

W: Pior que os garotos da escola. Ou meus pais. Sabe como eu aguento?

Desde que eu era pequeno, eu jogo esse jogo em que finjo ser uma pessoa diferente, a pessoa que eu sonho ser, meu verdadeiro eu. Tenho até outro nome: Unique.

Fiquei tão nervoso que quase nem falei com vocês hoje.

Daí pense, como Unique faria isso?

K: E a NYU? Espere. Guarde para depois.

Alguém de gosto extravagante está usando.

Unique: Joy de Jean Patou.

Kurt Hummel e Mercedes Jones, Unique venera o tapete vermelho onde andam. Se tivessem um filho, seria Unique. E os 
avós de Unique seriam André Leon Talley e Beyoncé, porque é só o melhor para Unique.

Sim bobos, é pele verdadeira. A não ser que pretendam manchá-la com tinta. Então é falsa!

$\mathrm{K}$ : Unique parece ser incrível. Espero que um dia tenha coragem de ser ele.

W: Na verdade, Unique é “ela”. Por isso quero seu conselho.

O regional é sábado e quero subir ao palco de vestido e salto alto. Porque está é a pessoa que sou por dentro.

K: ÚNICA.

$\mathrm{W}$ : Sim. O que você faria?

Wade/Unique busca aconselhamento com Kurt (Christopher "Chris" Paul Colfer) e Mercedes (Amber Riley) a respeito de suas incertezas. Wade/Unique deseja se aconselhar sobre como deverá se vestir durante uma apresentação do Grupo de Coral, Vocal Adrenaline. Deve caracterizar-se de Wade ou de Unique? Como esperado por uma cultura repressora, Wade/Unique é advertido sobre as possíveis consequências dessa atitude. Mais uma vez a heteronormatividade é apresentada à Wade: há limites para subverter um sistema. Para Foucault (1991, apud CAPOLINI, 2009):

[...] é a partir da norma engendrada socialmente que se estabelece o conceito de normal ou desviante, inferindo diretamente nas relações sociais, onde através de agenciamentos rizomáticos produzem-se discursos instituídos e produtores de estigma, delimitando e capturando os desejos. 
Por sua vez Melo (2013) destaca que:

[...] mediante estes pressupostos, outras práticas discursivas ditas singulares, que não são enquadradas nas ditas regras, agenciarão marcas em modos de subjetivação, sendo atribuído aos sujeitos um estigma social e consequentemente relações de exclusão. Essa demarcação de território de desejo e de possibilidades de existência, através de dispositivos heteronormativos, desloca o sujeito entre uma infração extremista da lei moral de forma brutal, permeando o campo do disciplinamento e por fim o campo sexual de onde se tem um suposto pudor em problematizar as experimentações de sexualidades dissidentes (MELO, 2013, p. 118).

Verifica-se nesse diálogo alguns alargamentos que a heteronormatividade vem sofrendo. É possível aceitar comportamentos homossexuais, afetações de gays, comportamentos lésbicos, heterossexuais travestirem-se dentro da cidade fictícia em que a série se passa, porém essa mesma sociedade fictícia, nos espaçostempos em que é representada, não aceitará que alguém do gênero masculino abra mão de seu poder para assumir uma personalidade feminina, subalterna, de menor valor. Para Foucault (apud Melo, 2013, p. 119):

[...] o agenciamento do biopoder e da biopolítica que de certo modo organizam o controle sobre a vida em todos os seus aspectos, principalmente em relação às questões relacionadas à sexualidade. Tem-se então uma estratégia de normatização e normalização dos corpos, através de regulações e disciplinas do corpo [...]. Dentro desse viés emerge como força dois dispositivos de deslocamento que acabam demarcando campos específi- 
cos de subjetividade: o assujeitamento às normas e/ou linhas de fuga e resistência.

Sardgna (2013) discute que:

[...] a inclusão escolar num duplo movimento: como uma política de regulamentação da vida e, ao mesmo tempo, como uma prática de regulação da população - composta não apenas pelos sujeitos ditos incluídos, mas por todos os alunos, seus professores, suas famílias, as instituições, os órgãos governamentais, enfim, a sociedade. Entendo que esses movimentos são estratégias biopolíticas direcionadas ao corpo-espécie da população que funcionam como tecnologias de dominação. As políticas educacionais são analisadas como ações voltadas para a população que se utilizam de racionalidades, estratégias e técnicas como instrumentos para dirigir condutas. A noção de governamentalidade é aqui utilizada nos termos biopolíticos, não restrita às práticas de governos no domínio político, mas como uma forma de agir sobre as possibilidades de ação dos outros (SARDAGNA, 2013, p. 45).

Wade é um personagem trans inserido na série estadunidense Glee, que traz à tona um debate muito profícuo e que tem gerado grandes tensões na sociedade moderna: a (trans) sexualidade $^{1}$. Wade é a representação desse conflito que está presente no cotidiano das escolas, porém distante dos currículos das mesmas. Ser trans em uma escola de ensino médio é lançar-se aos leões. É declarar guerra às normas. É atrair o olhar vigilante de uma sociedade heteronormativa sobre si. Ao verbalizar sua identificação com o gênero feminino Wade/Unique passa a fazer uma nova narrativa de si?

1 Escrita que possui o propósito de ressaltar os conflitos sociais existentes não só para a regulação das sexualidades abjetas, mas todas as sexualidades. 
Zorzal (2014) nos relata em uma análise de um relato de experiência que para sujeitossujeitas que possuem marcas de gênero que não se encaixam/atendem as expectativas habituais sobre os corpos, emergem um turbilhão de questionamentos. A mera existência desses corpos dissidentes nos causa estranheza, já que não se encaixam nos moldes de masculinidade e feminilidade instituídos. A grande questão é que essa situação em espaços formais e não formais pedagógicos nos levam a problematizar qual o potencial de desestruturação das normas vigentes, da heteronormatividade. E não podemos esquecer o grande potencial existente nas escolas para reproduzir, entre tantas outra coisas, a representação diminuta de uma sociedade com todas as suas instituições de poder cristalizadas.

Travestir-se de Unique é para Wade acomodar-se em uma subjetivação de gênero que lhe cabe (como um vestido) e lhe permitirá conviver como igual entre todos os outros que compõe a comunidade fictícia em que a série passa. Unique permite que Wade sinta-se respeitado, "quiçá" numa posição de superioridade. Essa noção de superioridade é expressa por Unique na $1^{\text {a }}$ cena, em um diálogo com Kurt e Mercedes. Em algumas falas, as atitudes de Unique assemelham-se a dos sujeitos que rejeitam Wade, tamanha a sua inclusão nessa sociedade.

Unique é uma possibilidade de Wade integrar-se, de estar em um grupo social. Unique interrompe, em alguns momentos, quando domina a personalidade da personagem, os abusos contra Wade. Unique possui essa habilidade social por que conhece a si mesma, e valoriza o que representa socialmente. Unique pode/ 
deve ajudar Wade a sentir-se seguro, por que conhece as fragilidades e monstros que atormentam Wade, e os domina.

Retomando Dallapicula (2014, s.p.) que disserta que as ideias sobre os corpos femininos são produzidas dentro de uma pedagogia pública da sexualidade, limitando ainda assim a capacidade de resistências que podem/são produzidas nos corpos. "Se o corpo não 'cabe' na norma, não permite existir, apenas resistir nesse contexto social". Dessa forma Dellapicula ratifica a ideia de que Unique, primeiramente, é uma adequação performática ao gênero com o qual Wade se identifica. Assim:

[...] se a natureza, por suas fantasias ou acidentes, pode "enganar" o observador e esconder durante certo tempo o verdadeiro sexo, pode-se desconfiar que os indivíduos dissimulam a consciência profunda de seu verdadeiro sexo e se aproveitam de algumas bizarrias anatômicas para servir-se de seu próprio corpo como se ele fora de um outro sexo (FOUCALT apud DALLAPICULA, 2014, p. 50).

Ainda segundo Dallapicula, o que importa nesse jogo é a enunciação produzida pelo corpo. Unique é a verbalização do gênero feminino no corpo de Wade Adams, e desta forma busca a todo custo que produzir os sentidos, trejeitos e movimentações que se assemelhem ao corpo feminino. É esse processo de simulação do próprio gênero que causa encantamento em Wade/Unique. Esse conjunto de procedimentos capaz de pronunciar enunciados, que é tido como verdadeiro, nesse tempo. A construção dessa imagemnarrativa pode ser comparada à realização de desejos por 
uma fada madrinha. Assim como nas histórias de faz-de-conta, aqui também se faz necessária a presença de diversos mecanismos de controle do corpo feminino, mecanismos esses personificados como vestidos, sapatos, cílios, cabelo, etc.

[...] as mulheres são doutrinadas pela ideologia do romance heterossexual através dos contos de fadas, da televisão, do cinema, etc, isto é, todos os mecanismos fazem propagandas coercitivas da heterossexualidade [...]

Através desses mecanismos, as mulheres seriam aprisionadas psicologicamente à heterossexualidade e tentariam ajustar a mente e o espírito a um modo prescrito de sexualidade (COLLING, 2014, p. 175).

Nessa cruzada Wade/Unique será postoposta à prova de diversas formas. Haverá mais chacota. Suas performances serão questionadas. Seu talento será questionado, embora saiba-se que não é o talento de Wade/Unique que "some", é o olhar que passa a ser direcionado à Unique que ganha outros contornos, e que modifica, de forma velada. Unique passa a ser enxergada sob a matriz heteronormativa, deixando assim de ser só a atração cultural e passando a ser uma abjeção social.

As transformações de gênero de Unique ao longo do episódio sinalizam o quanto disforme está a sua personalidade. Unique é dominante enquanto força de expressão e subjetivação, porém mesmo essa força avassaladora que é a personalidade de Unique, titubeia e duvida de sua capacidade de suportar as "capturas" que a heteronormatividade inflige às formas desviantes de sexualidade. 
Neste episódio fica evidente, que similarmente ao cotidiano da nossa sociedade, o quanto as abjeções sociais causam insegurança às expressões de sexualidade presentes no dia a dia da escola.

Muito da insegurança que Wade vive no episódio está alicerçado na sua não compreensão do por que sente/é diferente. Á medida que Wade tenta encontrar justificativas para ser diferente, naturaliza a heterossexualidade compulsória e oculta a produção da anormalidade. Colling (2014) analisa e identifica vários instrumentos que no processo de naturalizar a heterossexualidade, incluída, nesse contexto, as normas relativas ao gênero.

Assim, começamos a ser criados/educados e também violentados para nos comportar como meninos ou como meninas, a depender da nossa genitália. Caso não sigamos as normas, começamos a sofrer violências verbais e/ou físicas. Ou seja, a violência sofrida por aqueles que não seguem as normas comprova que a norma não é natural. Se assim o fosse, a violência não seria necessária, pois todos e todas nasceriam e se comportariam desde sempre como heterossexuais (COLLING, 2014, p. 177).

O autor retrata, nesse episódio, outras formas de enunciação da heteronormatividade e dessa forma representa no episódio o alargamento da norma, pois sinaliza haver uma melhor aceitação cultural por gays "limpos", ou seja, aqueles que causam menor desconforto à sociedade.

Nesse contexto de afirmação da masculinidade entre homens gays, ainda que a masculinidade para estes se ancore no modelo hegemônico domi- 
nante, é possível que estejamos lidando com um conjunto de práticas que sejam exclusivas para a construção da masculinidade desses grupos, tornando sua compreensão mais complexa [...] estas ainda redundam na manutenção da norma, contribuindo para a distinção entre masculinidade hegemônica e masculinidades subordinadas (BUSSINGER, 2013 p. 145).

Wade/Unique enquanto travesti é uma personagem que traz para o seriado a polaridade existente nessesnessas sujeitos, que alternam entre masculino $\mathrm{x}$ feminino. Essa polaridade ocasiona socialmente uma incapacidade de localizá-los em um código. Essa forma de ser/existir é a materialização de modos de vida e de masculinidade que não são uma forma desejante de/na normatização dos corpos (RODRIGUES, 2014).

A normatização dos corpos aparece durante a trama nos discursos de outros personagens, que verbalizam alguns mecanismos de aprisionamento que são engendrados pela/na escola, família, professores, colegas e sociedade. Wade relata durante o episódio que os assédios constantes que sofre do professor são mais cruéis do que todos os outros.

Para Foucault (2013) os discursos sobre a sexualidade dos sujeitos são necessários na medida em que se constituem em mecanismos pedagógicos que a sociedade se utiliza para configurar o que é normal e o que é abjeção social. Foucault discute a grande utilidade do falar sobre sexo e sexualidade, não para tolerar ou condenar, mas para gerir, inserir sistemas de utilidade, regular o bem para todos, fazer funcionar segundo um padrão ótimo.

Bento (2012) corrobora com o que é tratado por Foucault 
ao dissertar sobre o projeto social de desumanização desses sujeitos, e nos revela que um dos espaços em que o projeto ganha concretude é na escola. Para a autora, a escola é também local de produção de abjeções sociais. Assim considerando:

[...] a produção de seres abjetos e a desumanização do humano é um projeto social que encontra nas instituições sociais o lócus para se re(produzir). [...] o ostracismo e a zombaria por parte de seus pares são sequelas especialmente comuns para meninos o transtorno (BENTO, 2012, p. 165).

Durante o diálogo em que Wade revela que Unique pertence ao gênero feminino, Mercedes alerta-o/a de que muito provavelmente aquela comunidade não o/a aceitará. Mercedes de fato compreende as possíveis batalhas que Wade/Unique enfrentará, pois já foi ela mesma alvo, por diversas vezes, de críticas e zombarias. De fato, Mercedes também é muitas vezes uma abjeção social dentro do espaço escolar.

Salih (2103) analisa como e de que forma os discursos performativos se materializam para causar sequelas nos sujeitos, e que o ato de pronunciar tais discursos tem propósito de insultar e sentenciar sujeitos. É essa sentença um ato enunciativo da diferença que não cabe àquele contexto, que há algo dissonante, e nesse compasso, o torna abjeção social.

[...] todo enunciado é ação, então chamar alguém de "crioulo" ou de "bicha" é fazer alguma coisa, isto é insultá-lo, de modo que existe apenas uma diferença de grau (e não diferença de tipo) entre essa ofensa verbal e, por exemplo, bater em al- 
guém ou jogar tijolo na sua janela (SALIH, 2013 p. 141).

Kurt, na mesma cena, discursa para Wade/Unique sobre os "limites" que existem para as transgressões, e até delimita alguns desses limites. Kurt rememora que até já se travestiu, porém crê que fazê-lo na presença de outros, em um espaço "inseguro", é um grande risco. Há também no diálogo o receio de Kurt ao perceber uma personagem que declara sua insatisfação com o próprio gênero.

Wade ao sinalizar para Kurt que se traveste para vivenciar Unique, verbaliza e denota sua grande identificação com o gênero feminino. $\mathrm{O}$ gênero feminino para a personagem é empoderamento. Já para Kurt as marcas do gênero masculino, mesmo que sua sexualidade dentro da narrativa seja uma abjeção, ainda é dominante.

Pinel (2013) nos aponta mecanismos de silencio e silenciamento em torno das homossexualidades masculinas no espaço escolar. $\mathrm{O}$ autor relata das imposições de bom comportamento, e discorre que esse processo de silenciamento é, dentro do espaço escolar, uma censura da fala. Pinel ainda nos alerta que o processo de silenciar também se constitui em subjulgamento e posição de inferioridade do sujeito homossexual, garantindo-lhe a não existência e o não reconhecimento.

Kurt e Mercedes estão temerosos com a reação que o incentivo que deram à Wade/Unique, a pedido de Sue Silvester, de que fizesse a apresentação do Vocal Adrenaline no gênero em que se 
identifica. Kurt e Mercedes sabendo das possíveis reações e julgamentos que recairão sobre Unique vêem-se obrigados a reparar o "dano".

Ao encontrarem Wade/Unique no camarim não conseguem dissuadí-lo/a de se apresentar como Unique. Há extrema confiança na voz e na atitude de Wade. O garoto introspectivo está extremamente altivo e decidido a fazer o que crê que deva e da forma que deve ser feito. Há uma mudança drástica na personalidade de Wade. Ao fim da cena podemos identificar por que Wade está tão confiante: as sandálias. As sandálias nos pés de Wade denunciam que a coragem é fruto da personalidade característica de Unique, ratificando que Unique é o empoderamento que Wade tanto deseja.

Silva (2004) discorre a respeito da valorização das qualidades do gênero feminino, à medida em que esse possui características extremamente desejáveis, ainda que pondere que enunciar tais características possa ser, para alguns grupos, enfatizar esteriótipos femininos.

Rodrigues (2014) aposta na plasticidade do corpo trans como disparador de mudanças, problematizações e indagações de como estar no mundo, à medida em que a sexualidade é uma produção de si que se faz e incide no mundo. Para o autor as representações das sexualidades como forma de poder, tecem maneiras de ser estar no mundo, os quais os discursos sobre elas não possuem propósito de reprimir atitudes, mas de instigar e incitar forma de fazê-lo.

Unique durante a apresentação do Grupo de Coral, Vocal Adrenalie, é personagem principal e solista da música "boogie 
shoes" . A música traduz e remonta o último diálogo de Wade/ Unique com Kurt e Mercedes: o desejo de Wade de ser Unique, e que esse desejo se concretiza ao colocar as sandálias, boogie shoes.

Dallapicula (2014) trata da personificação do gênero feminino com a utilização de apetrechos, assim como também denuncia esse aprisionamento dos sujeitos trans à performances e marcadores de gênero. É, dessa forma, possível identificar uma pedagogia da sexualidade, que se constitui em materialização de um poder pastoral orientador da sexualidade feminina.

\section{CONSIDERAÇÕES FINAIS:}

Analisando todas as reflexões que fizemos a respeito do seriado de Glee: Glee-Embalos de sábado à noite, percebemos que Ryan Murphy traz à luz toda a complexidade e polêmica que envolve a temática: comportamento travesti no cotidiano escolar, e que o autor também nos propõe a percebermos as aflições/ tensões/humilhações/subserviência a qual esses sujeitos são impostos no espaço escolar.

$\mathrm{O}$ autor trata com profundidade a temática sexualidade ao analisar as performances e subjetivações do personagem fictício, Wade Adams e, à medida que a narrativa se desenrola podemos inferir que o autor tenta nos propor a refletir sobre o cotidiano e compartilhar um pouco da dor da personagem, assim como Pinel (2013) disserta: "modos de ser sendo junto ao outro no mundo".

1 Boogie Shoes é uma canção popular lançada em 1975 no álbum KC and the Sunshine Band pela banda com o mesmo nome, $\mathrm{KC}$ and the Sunshine Band e regravada no Episódio Glee-Embalos de Sábado à noite. 
O autor para constrói o personagem Wade/unique com excesso de marcadores de gênero e de forma muito antagônica, e em nossa análise isso é proposto na série para trazer um debate acalorado de idéias sobre a temática: travestismo e transexualidade. $\mathrm{O}$ autor delineia Wade como um garoto tímido, vulnerável, completamente fragilizado e deslocado dentro do espaço escolar, já que não se encaixa, não se enxerga, dentro do gênero masculino.

$\mathrm{O}$ autor Ryan Murphy narra a personagem Wade/Unique, assim como a grande maioria dos personagens da série, como representantes de micropolíticas produzidas pela existência das abjeções sociais. Os personagens criados na série por Ryan são identificados como "perdedores", e essa também é uma forma do autor "sublinhar" mais rótulos que são criados socialmente. Nesse compasso de criação da série, os questionamentos que fazemos ao longo do ensaio são o fato de que para afirmar as diferenças existentes em nossa sociedade o autor faz contraponto à norma vigente, e dessa forma reafirma a heteronormatividade.

Dentre as discussões que surgem dentro do episódio está a marcação de gênero com que o autor delimita a personagem Unique, e para nós essa construção é uma reafirmação da heteronormatividade, ao passo que a construção das subjetivações e performances do corpo travesti de Unique são delineadas por características desejáveis e admiráveis do gênero feminino.

O autor, no episódio, constrói diversos pontos de debate em torno das marcações de gênero e sexualidade. Outro aspecto que é introduzido pelo autor é o empoderamento do gênero feminino, 
algo pouco comum em nossa sociedade. Unique é um contraponto em relação à personalidade de Wade. É altiva, segura, determinada, confiante. É nesse aspecto que concordamos com Rodrigues e Barreto (2012), que apresenta o corpo e suas expressões enquanto impossibilidade de existência e lócus de resistência.

Ao longo da série o autor tenta trazer para o debate a idéia de um corpo enquanto produção política de si mesmo, que é capaz de produzir sujeitos de desejos criados nas relações de poder. Também é possível, através da narrativa do autor, percebêlo comparar o corpo com os vários outros espaços de produção de política onde o poder se ramifica, se disputa e se constrói. O corpo tem se tornado espaço de disputa de poder entre a norma vigente e as micropolíticas libertárias produzidas por sujeitos que são abjeções sociais.

Durante o episódio o corpo de Wade/Unique é importante espaço (re)invenção e inovação na experiência de si. Como aponta Rodrigues, Dallapicula e Ferreira (2014) é o corpo se esvaziando e se preenchendo com uma série de dispositivos e mecanismos disponíveis e revolucionantes. Unique recorre a diversos dispositivos enunciativos para se produzir no gênero feminino, que se constituem em performances reservadas a esse gênero.

Entre outros aspectos, podemos perceber o autor tentado traduzir da forma mais próxima da realidade as práticas discursivas que são adotadas socialmente como forma de captura dos sujeitos desviantes. É durante o diálogo entre Wade/Unique, Kurt e Mercedes percebemos que o autor tentar retratar algumas formas de alargamento da heteronormatividade. Esse processo de 
alargamento cria discursos em sujeitos abjetos, de forma a agenciar marcas de subjetivação e estigma social, deslocando o sujeito para uma infração extremista da lei moral. Mais uma vez o autor da série traz a luz uma série de devires que problematizam o pudor e rigor social com que serão tratadas as experimentações sexuais dissidentes.

No contexto do episódio podemos concluir que há um retrato social de afirmação da masculinidade, mesmo entre homens gays, e ainda que a masculinidade no episódio se ancora tanto nos medos e represálias a que sujeitos abjetos serão submetidos. Percebemos ainda que há por parte do autor propósito em retratar com a maior fidelidade os aspectos atualmente presentes na sociedade moderna, e entre elas, a heteronormatividade.

Por fim, podemos concluir que o autor Ryan Murphy, no episódio Glee-Embalos de Sábado à noite, delineia como muita propriedade discussões a respeito de sexualidade, gênero e suas performatividades. E propõe-se a fomentar uma discussão de forma imparcial e a retratar as nuances dessa discussão tal quais essas se apresentam dentro de nossa sociedade.

É então o episódio de Glee, enquanto produção de obra de arte possível de nos fazer refletir sobre as políticas pensadas para os sujeitos travestis e transexuais, e assim podemos também refletir e repensar discursos que inviabilizam e excluem os sujeitos desviantes e marginalizados pela norma vigente. Em suma, mesmo que não possua propósito educativo, o episódio o é na medida em que nos propõe a repensar o que afeta, no cotidiano, o meu companheiro. 


\section{REFERÊNCIAS:}

BENTO, B. O que é transexualidade. $2^{\mathrm{a}}$ Edição. São Paulo- SP. Coleção Primeiros Passos, 2008.

FABRIS, E. T. H.; KLEIN, R. R. Inclusão e Biopolítica. $1^{\text {a }}$ Edição. Belo Horizonte -MG. Editora Autêntica, 2013.

FOUCAULT, M. História da Sexualidade: a vontade de saber. $23^{\mathrm{a}}$ Edição. São Paulo - SP. Editora Paz e Terra, 2013.

PINEL, H.; MENDONÇA, C. (Orgs.). Diversidade Sexual: Silêncio, Diálogo \& Currículo. $1^{a}$ Edição. São Carlos - SP. Pedro e João Editores, 2013.

RODRIGUES, A.; DALlAPICULA, C.; FERREIRA, S. R. da S (Orgs.). Transposições: Lugares e Fronteiras em Sexualidade e Educação. $1^{a}$ Edição. Vitória -ES. EDUFES, 2014.

RODRIGUES, A.; BARRETO, M. A. S. C (Orgs.). Currículos, Gêneros e Sexualidades: Experiências misturadas e compartilhadas. $1^{\text {a }}$ Edição. Vitória -ES. EDUFES, 2012.

SALIH, S. Judith Butler e a Teoria Queer. $1^{\text {a }}$ Edição. Belo Horiezonte -MG. Editora Autêntica, 2013.

SILVA, T. T. Documentos de Identidade: Uma introdução às teorias do currículo. $2^{\mathrm{a}}$ Edição. Belo Horizonte - MG. Autêntica Editora, 2004. 


\section{DE SAPATILHAS OU SAPATÕES: O PALCO DAS ATRIZES CONTRATADAS POR ENGANO}

Steferson Zanoni Roseiro Nahun Thiaghor Lippaus Pires Gonçalves Edmar Reis Thiengo

\section{UMA DANÇA INTRODUTÓRIA}

Duas moças sobem ao palco - nem mulheres, nem garotas. Moças, no indefinido da idade, no indefinido do corpo. Uma, inclusive, não expressa nada: sua face está coberta de um longo tecido vermelho e, nela, apenas ataduras cobrem partes de seu corpo. Tecido esse que se estende por toda a plateia; muitas mãos os seguram, prendem e, por vezes, puxam o pano. Reiteram as amarras. Mas, na frente de todos, as duas ainda dançam ritmos desconcertantes.

A modo introdutório, todos dançamos esses ritmos, embora, em muitos momentos, prefiramos afirmar apenas um ritmo sob nossos pés. Parece mais fácil dizer que valsamos uma musicalidade comum; menos desordeiro dizer "Ah, eu prefiro o samba ou o bolero". E nem falamos de gostos musicais aqui. Referimo-nos aos consensos e às categorizações em contrapartida a uma pergunta simples: por que eu deveria me identificar com o não identificável? Por que eu deveria reconhecer que, por onde meus pés 
passam, eu deixo uma pegada passível de me capturar, de me reconhecer, de me retalhar? Por que admitir que o caótico tem força o suficiente para nos desestabilizar?

Imagem 01. Sapatinhos del Diablo (SCHULZ, 2014).

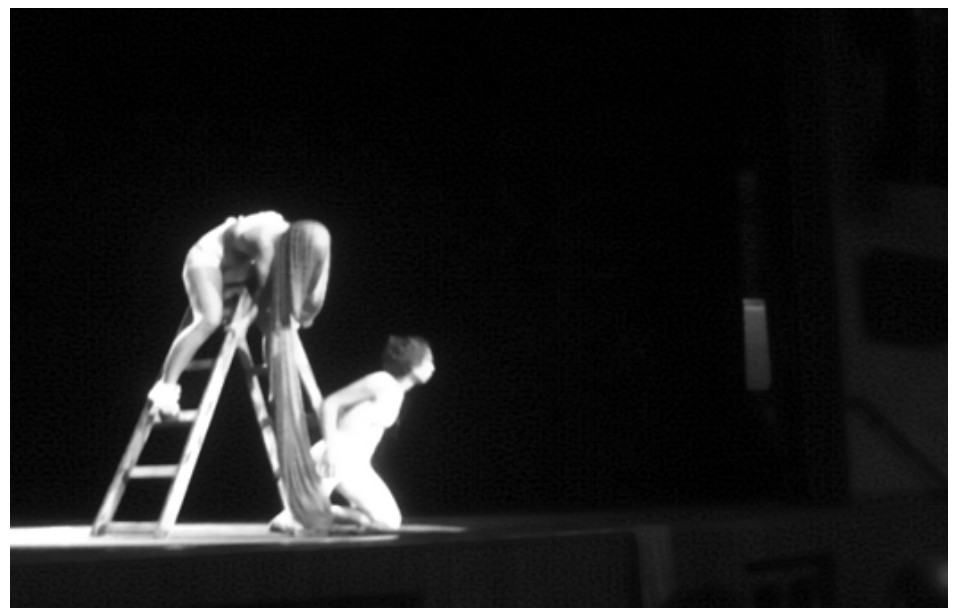

Fonte: Acervo pessoal.

Mas esse não é um texto tão vago que fala de tudo e de nada. É apenas um corpotexto, uma escrita pequena e arriscada na tentativa de trazer as duas protagonistas do palco a conversarem com uma escola indefinida em um tempo vagamente definido: o contemporâneo.

As duas moças são personagens de uma apresentação artística ocorrida em um grande seminário na cidade de Vitória nos dias 29, 30 e 31 de julho de 2014, o III Seminário Nacional de Educação, Diversidade Sexual e Direitos Humanos. Elas foram a abertura artística de uma noite de conversas, e, entre tantas coisas, elas falaram do quanto a sociedade - as escolas, nosso foco - 
amarram sapatilhas em pés de moças e, com estas amarras, são forçadas a dançar o que os Sapatinhos del Diablo ${ }^{1}$ (SCHULZ, 2014) impõem. O que as danças únicas, homogêneas e normativas ditam.

Eis, então, este corpotexto, este ensaio. Um ensaio que é tão pé-no-chão quanto poderia sê-lo uma pesquisa, afinal, muitas narrativas atravessam os espaços por nós transitados. Um ensaio que é também uma tentativa de dizer o quanto transitam nas escolas (imaginárias, indefinidas, inventadas, impositivas...) atrizes implorando para rasgarem as amarras, para descosturarem os sapatinhos. Rogam, enquanto dançam, ainda que nunca chorosas, para não serem sapatilhas ou sapatões o que lhes prende, lhes tortura. Para não serem pisoteadas pelo que lhes encantam...

Nas escolas essas atrizes não são sempre mulheres, não são sempre pessoas nascidas no gênero feminino. Elas, inclusive, não precisam querer subir aos palcos escolares. São carregadas, tornam-se atrizes como uma garota pode se tornar garota de programa - por todo um conjunto de situações em que ela não se vê apta a escapar. Essas atrizes são, entretanto, na certa atrizes, no gênero feminino: o primeiro bloco de singularidades ao qual se atribui certas características "insuficientes". Na mulher sempre falta algo que a poderia fazer ideal. Ou ao menos assim circulam os discursos. As faltas são ainda mais intensas se a imagem feminina é um pouco deturpada - é uma mulher menos delicada? Um problema. É uma mulher no corpo de um homem? Outro

1 Nome da apresentação supracitada. A abertura ocorreu no dia 29 de julho de 2014 no Teatro Universitário da Universidade Federal do Espírito Santo. 
problema. Uma mulher com outra mulher? Um perjúrio. Uma bicha? Leva para terapia. Um homem-afeminado heterossexual? Um excesso de problemas!

Delirante se faz esse ensaio ao apostarmos numa cartografia-sensível - a arte de produzir mapas - como um levantamento de problemáticas nos palcos escolares e, também, de possíveis diálogos para as práticas educativas. Decerto, essas práticas já acontecem em algum lugar, por alguns praticantes do cotidiano escolar; seria estupidez nossa achar que estamos propondo algo impensável. No momento em que pensamos, outros também podem fazê-lo. Nossa proposta, então, é enriquecer os espaços de pensar a educação, de pensar o fazer docente. E, em uma cartografia, esperamos acolhê-lo nessa escrita e fazê-lo sentir as problematizações e as intensidades de quem está no palco. Então que nos permitam, neste momento, chamar-lhe de bicha ou lésbica ou travesti ou drag queen ou mariquinha ou puta ou qualquer outra palavra de gênero feminino usualmente pejorativa, sem, contudo, lhe faltar com respeito. É, ao contrário, um elogio! Você sobreviveu - e sobrevive - aos massacres dos sapatinhos, das sapatilhas, dos sapatões!

E, por esta razão, todo esse corpotexto é elaborado. Um ensaio que objetiva atravessar os palcos nos/dos cotidianos escolares e, neles, trazerem à tona problemáticas vividas pelas atrizes que calçam os sapatinhos, as sapatilhas, os sapatões... Sempre mantendo na escrita aquela pergunta que, em algum momento, insistirá em retornar: por que nos atemos tanto às amarras das coisas e dos lugares? 


\section{UMA QUESTÃO DE CONTOS DE FADAS}

É um tesouro para a mulher a formosura,

Que nunca nos fartamos de admirar. Mas aquele dom que chamamos de doçura

Tem um valor que não se pode estimar.

Pêrrault

O conto de Cinderela ou o sapatinho de vidro, de Perrault, decerto é uma história antiga, e, portanto, situada historicamente, as problematizações não poderiam ser as mesmas que fazemos hoje. Todavia, ao pensar que o conto foi relançado no ano de 2010 em uma edição atraente para crianças resgatando uma questão moral (lição de moral) nos faz questionar as práticas moralizantes, ainda vigentes, em nossas escolas, sociedade, contos de fadas, etc.

Contos de fadas, de maneira geral, assim como fábulas, são repletas de lições de moral. A moral, como coloca Foucault (2013), é uma questão de práticas e discursos definidos como aceitos e "necessários" para uma organização social. É moral aquilo que defende os bens de quem pensa a organização social. A moral vira, então, discursos de "verdade", os quais, por sua vez, estão envoltos em ações políticas maiores as quais ditam o que pode ser legitimado e o que deve ser deslegitimado. Essa prática discursiva é contínua e não se prende a um único "espaço", acontecendo em todo o lugar e em todos os momentos. Enfim, a moral é um acordo das políticas de verdade favoráveis a grupos organizadores da sociedade. A escola, enquanto instituição, é tanto produtora quanto difusora desses discursos morais. 
Nesse contexto, a primeira problematização a qual lançamos se faz na ordem das produções e perpetuações dessas morais. A moral, sempre entendida como um acordo consensual, impossibilita pensar a diferença. Em discursos morais, criam-se ideais, e, como no simulacro de Platão, tudo aquilo a qual se afasta o ideal, é desconsiderado, deve ser apedrejado.

Assim surge o palco. Um palco como lugar de desencontro com o "ideal"; o palco como espaço de atuação de quem é "imoral". O palco é, aqui, onde as atrizes (inesperadas) são empurradas, como que contratadas por engano.

Mas não fique enciumado! Você também é uma moça de pouca formosura e de doçura questionável; é um moço de doçura excessiva e de formosura aflorada. É também uma mulherhomem, uma imagem nem no "homem" nem na "mulher", mas, decerto, com um pouco de mulher em seu corpo (ROSEIRO, 2014). E você talvez questione os contos de fadas. Enquanto criança, enquanto mocinha da educação infantil, você pergunta por que os meninos precisam fazer caretas para as princesas dos contos de fadas e por que as meninas precisam se apaixonar pelos príncipes.

Vidal e Neuls (2006) contam-nos como mesmo em contos de fadas contemporâneos, quando as personagens femininas tomam atitudes (ditas) menos femininas, há, na própria narrativa, certa censura. Nas escolas, essa censura parece ser redobrada, quando, além da própria escrita que tenta fazer as personagens parecerem menos interessantes, as professoras e professores afirmam padrões de comportamento de meninas e meninos. E essas falas, nas escolas, não precisam ser uma ordem direta, aparecen- 
do, na maioria das vezes, em enunciados autolegitimadores: uma menina não pode dar uma surra em um rapaz, mas pode esperar pelo herói (príncipe, lenhador, garoto...) para salvá-la. O verbo salvar, vira, assim, desculpa para a violência, mas só é aceita se partindo de personagens masculinos. Como diz Beiras et al (2007), a violência do herói é sempre perdoada, afinal, ela tem a intenção salvadora, ainda que a luta seja desnecessária ou sem sentido.

Este reforço do papel masculino implica, assim, no oposto do que deve ser a mulher. Quando a discussão é de gênero, parece haver apenas espaço para dois padrões normativos - coisa de menino, coisa de menina. Não, pode não. Isso é uma boneca, é brinquedo de menina. Se se troca o a por um o, o menino poderia brincar de boneca, de balé, de corda, de ser menina... em nossa língua, o gênero é sempre transitório, e, na maioria das vezes, a transição é de apenas uma questão entre duas vogais. Não, entretanto, nas ações de gênero; no campo do real, toda tentativa de fuga em gênero é ameaçada pela captura de uma grande máquina de produção de moral, de modo "correto" de ser e estar em gêneros.

Nos contos de fadas, é papel do príncipe aparecer para o dia ser salvo. Mas, nas escolas, onde a vida é rica em tudo o que foge à normatividade, encontramos nossos incômodos facilmente personificados na afirmação do não pode - "O que nos incomoda e continua incomodando são as inúmeras tentativas de controle sobre o corpo que pulsa" (GOMES; FERRAÇO, 2013, p. 187). Mas os cotidianos também são reinventados; fogem aos contos de 
fadas e seus finais sempre idênticos, às histórias sempre repetidas. Nas escolas incide um fluxo natural de inventar novos modos de agir "não autorizados".

\section{MOVIMENTO I. ESSA DANÇA DO PALCO QUE NÃO CABE NÓS DUAS}

Você entra na escola. Está de mãos dadas a alguém, ou melhor, há um tecido fino e pesado envolvendo as mãos de vocês. Você não é mais apenas uma pessoa, mas uma singularidade de duas pessoas. Vocês são as duas atrizes. E desde o momento que cruzam o portão da escola, o silêncios são produzidos, ainda que silêncios barulhentos e assustadores. Silêncios de exercício de pressão.

Vocês duas - sempre duas, no feminino, e, por favor, lembrem-se ser bichas ou sapatões ou tudo o mais que puder fugir ao masculino normativo - têm um momento de força, erguem a cabeça, sorriem uma para a outra, e pisam firme em todo o caminho do pátio.

Como não poderia deixar de ser, aquele não é o início do ano letivo. Vocês já passaram por outras escolas, privadas e públicas, e, sem nenhuma pressão, as famílias de vocês optaram por removê-las das escolas. Elas são carinhosas e caridosas com vocês. Apenas querem privá-las da fofoca do bairro em que mora. Então, agora, vocês precisam pegar dois ônibus de meia hora cada para chegar à escola. Mas isso tudo é amor, é para o "bem" de vocês.

E esta nova escola, com certeza, sabe o que é melhor para vocês. Por isso as colocou em salas separadas - mesmo estando, 
ambas, no mesmo ano escolar. É uma escola grande, não foi a intenção da gestão da escola separá-las! Vocês são muito bem-vindas aqui! Temos todo o tipo de diversidade aqui... e são todos muito queridos! Pode perguntar ao menino surdo do $7^{\circ}$ ano! Ele se dá bem com todo mundo... cumprimenta todos e até tenta conversar! E, após essa fala, uma de vocês foi para uma turma com 43 alunos; a outra divide a sala com outros 29. Uma separação justa.

Mal saem da sala da pedagoga, um rapaz para vocês duas de supetão e, debochado, pergunta qual das duas é a mulherzinha da relação. E, para vocês, duas opções viáveis aparecem e lhes agradam muito, mas uma agrada mais. Não sabem quem, mas uma de vocês duas enfiou a mão na face dele e, agora, estão na sala da coordenadora.

Essa é uma história, curta e apenas introdutória, das atrizes que estão nesse palco que foge à normatividade. Ao longo da história, poderia dizer a coordenadora, essas vidas que se colocam no palco foram extintas de todas as formas possíveis: em instituições próprias (cadeias e manicômios), invisibilizadas por políticas de direitos igualitários, em massacres, em "correções" (psicológicas, jurídicas, religiosas, científicas, pedagógicas, etc.).

Vidas deslegitimadas e inferiorizadas socialmente que, mesmo após a democratização recente do país, sofrem a violência do aparato policial e do ódio religioso, cujos efeitos se fazem presentes na violência espetacularizada ou cotidiana que continua reificando vidas tomadas não humanas ou menos humanas (NARDI, 2014, p. 217). 
Nardi (2014) discute, assim, esses campos de produção de moral, de genocídio do imoral, mesmo e principalmente quando esse imoral é justamente um afastamento do "ideal" identitário, e, portanto, imoral é quem prejudica a moralidade do outro. É imoral por se apresentar um risco às lições de moral. Há toda uma produção de práticas a serem consideradas em dois grupos binários: moral e imoral. E, quando em sociedade, todo um tipo de força (no campo físico, teórico, ético, político, imagético, de consumo, etc.) trabalha para correção do imoral. Os ideais morais não são apenas força de repressão (FOUCAULT, 2013) - embora também o sejam - eles funcionam, antes, como dispositivos de fascinação: é preciso que os padrões morais sejam almejados e desejáveis, e, portanto, precisam alegar nascerem de um consenso, de um grupo “maior”. E, na vida política (anti) ética e binária, algo só pode ser valorizado se o outro lado é transformado em pejorativo, em negativo, em ruim, imoral.

Como coloca Baptista (1997), o problema não começa quando o garoto esperava por vocês duas fora da sala da pedagoga, mas quem, antes, remete ao discurso de mulherzinha, e, portanto, de papeis de homem e papeis de mulher. Ele nos leva, assim, a pensar em quem o autor chama de amoladores de facas. Esses amoladores não se situam em lugares de criação de conflito, mas de redução do outro. Criam, na visão estereotipada da sociedade, uma causa individualizada, atribuindo ao diferente um problema que lhe é pessoal. Os amoladores, assim, quase justificam os genocidas. Ao entrarem na sala da coordenadora, vocês poderiam ouvir toda uma série de falas que lhes atribuiria a cul- 
pabilidade pela agressão. São diferentes, e, portanto, são um "defeito" da natureza.

Ou talvez fossem culpabilizadas individualmente. Na típica frase "Uma de cada vez", vocês poderiam ver o tecido fino e pesado se esticando e ficando menos e menos pesado.

Toda esta lógica moralizante e de culpabilização é referida como justificativa para o longo processo de exclusão vivido na história. Se hoje se questionam, nas escolas, o potencial de aprendizagem de crianças sem pais envolvidos nas atividades escolares, ou as meninas e meninos que vão para escola por causa do um programa de assistência, é porque, em algum momento em nossa história, essas mesmas crianças foram consideradas imorais de algum modo. $\mathrm{O}$ ainda recente processo de inclusão dos considerados imorais é questionado constantemente. Não podem, entretanto, ser encarados menos como uma força contrária à inclusão e mais como movimentos de rupturas pequenas diante da resistência histórica em torno desses sujeitos (FOUCAULT, 2013). Seríamos, contudo, ingênuos em acreditar que todas as movimentações são favoráveis à inclusão dos imorais - nas escolas, instalam-se fortes torres de rigorosidade moralista, agindo nas práticas e enunciados dos sujeitos fetichizando passado excludente. Muito provavelmente o encontro de vocês duas com esta coordenadora foi um vestígio dessas torres de marfim.

Somos, contudo, esperançosos. Então prossigamos com os movimentos.

Quando finalmente juntas, há, agora, um pouco de vergonha. Caminham pelos corredores, já não mais tão juntas. E, 
no caminho das salas de aula, despedem-se com um aceno fraco. Não dão as mãos, não se beijam. Ficam um pouco sem graça ao se olharem, sem saberem o que fazer. Mas logo o corredor decide por vocês - sai de uma sala vizinha um garoto. Ele lhes vê, ergue uma sobrancelha; nada fala. No medo, vocês correm para a sala de vocês. Sem uma única palavra. Apenas o peso do tecido a diminuir.

\section{MOVIMENTO II. FAZENDO O QUE FOMOS PAGAS PARA FAZER}

Todavia, não para sempre podem viver da vergonha, logo, em algum momento ainda naquela primeira semana ou na próxima, vocês resolvem o contrário do que fizeram: se há um espetáculo em andamento, que sejam, por fim, as atrizes que foram pagas (em péssimas moedas) para ser.

Despir-se da vergonha lhes leva a beijações, a pegações, a amassos e, com certeza, a gritos escandalizados de professoras e professores, coordenadoras de cara feia, de diretor bufante, de pedagogas fazendo cruz. Com indiferença, vocês duas não perdem tempo em lhes pedir desculpas ou espaço. Estão no palco que lhes empurraram, então precisam manter o show.

Na apresentação de Deborah Schulz (2014), o longuíssimo pano vermelho é arrastado pela plateia e cada mão é uma âncora, uma amarra dos sapatinhos. Não têm nomes - nunca nos apresentamos! -, mas cada um é um pequeno mecanismo que prende e pesa no tecido em volta de suas mãos. Uma amarra social. Vocês se afastam e o peso diminui. Não é um problema no rela- 
cionamento de vocês duas, mas por causa dele. Os mecanismos de amarra são tão mais fortes quanto mais próximas estiverem. É força de (re)tração. São as pessoas colocando mais força para lhes afastar, dificultando o caminho de vocês na diferença. Os pesos parecem sempre gritar: "normalizem-se!".

Agora, contudo, vocês estão aguentando à força de atrito. As pessoas não falam menos, não cochicham menos, não gritam com menor intensidade, não deixaram de tentar lhes fazer cair ou sequer estão usando apelidos mais carinhosos. Ainda são sapatões e/ou bichinhas e/ou mariquinhas... ainda perguntam quem faz o que. A diferença é que agora vocês respondem. Afiaram as línguas, um trabalho avesso de um amolador de facas, e danaram a falar. As pessoas não se calam, mas riem, indiscretas e/ou assustadas, com as respostas de vocês. Aos poucos, sob o palco parecem surgir cadeiras cômicas.

E entre a comicidade e a sinceridade de vocês, parece surgir um pouco de conversa.

\section{INTERLÚDIO. OUTROS MODOS DE APRENDIZAGEM?}

Nas conversas que começam a surgir, as duas atrizes deixam de ser apenas estranhas, esquisitas, motivos de chacota, etc. Ainda provocam estranhamentos, e, com isso, ainda estão sob holofotes, arrancando o pensamento petrificado do lugar e começando a produção de uma escola não engessada, não dogmática.

Holzmeister e Lopes (2012) apontam para o atravessamento contínuo da diferença no currículo escolar, no cotidiano escolar. A prática docente não consegue ser a mesma, mesmo se tentasse. $\mathrm{O}$ 
professor, diante de todas as tensões a qual se vê envolvido, tenta achar modos de continuar a caminhada sem que isso implique no fim de sua atividade educativa. O currículo - não mais entendido apenas como uma lista de conteúdos, mas como todo o conjunto de atividades realizadas na escola pelos praticantes da educação (CARVALHO, 2009) - tem esse caráter intempestivo: invade os territórios escolares e arranca todas as formações pétreas do lugar, revolvendo-as em turbilhões intensivos de acontecimentos.

Desse modo, a conversa se estende entre as atrizes por engano e os outros praticantes da educação (professoras, pedagogas, coordenadoras, discentes, serventes, merendeiras, porteiro, guarda, familiares, diretor...). A cada conversa, os estranhamentos se intensificam, mas, agora, em outros modos: são estranhamentos não apenas ofensivos, são curiosos, são, talvez, desejáveis. Começa a crescer entre os praticantes e as atrizes pontos de conversa e, nesse segundo movimento, outros tantos são desencadeados. Toda ação posterior é, então, um micromovimento iniciado pelo clímax do segundo.

Nessas rodas de conversas insurgentes, professores viram colegas das atrizes e, em movimentos diferenciados, interessam em buscar diálogos. A escola chama pais, e descobre, talvez, a existência de casais homoafetivos pais de crianças da instituição. E, quem sabe, essas crianças sejam, ainda, crianças alegres, reconhecidas pelos professores como "boas alunas" e entre os colegas como "pessoas legais". Com a comunidade escolar e dos arredores poderiam, por exemplo, começar discussões sobre sexualidades nas escolas. Não precisam falar apenas de 
homoafetividade; só de começarem a combater a sexualidade hegemônica já seria um primeiro passo. E esse combate já começaria ao falar que também a mulher tem o direito de sentir desejos sexuais. Com mais intensidade, toda uma conversa de feminilidade e feminismo poderia dar continuidade.

Eis que nada disso é utópico. As escolas tentam fazê-lo quando, por exemplo, abrem os braços e dizem ser, ali, espaço para um travesti, uma transexual, um professor reconhecidamente drag queen. $\mathrm{O}$ estado e os municípios também se movimentam quando passam a reconhecer (ainda que legalmente citar lei, decreto...) o uso dos nomes sociais. Também o seminário referido no início desse texto foi um espaço de tudo isso, em que muitas prefeituras, secretarias de educação, docentes, discentes e pessoas tantas estiveram presentes não apenas para ouvir apresentações científicas, mas também para oficinas, filmes, apresentações artísticas, fotografias, conversas, encontros...

Na potência dos encontros e das conversas, outros modos de aprender forçam seu caminho para se estabelecerem. As professoras, quando de encontro com as sexualidades, estranham, e, em seguida, buscam compartilhar esses estranhamentos e produzir outros sentidos (SILVA; ROSEIRO, 2014). As conversas com esses estranhamentos se fazem, então, produções de outros lugares em que antes a diferença não era pensada. Passam a existir diferentes lugares nas conversas nas/das escolas.

Ao contrário da lógica moralizante dos contos de fadas, as conversas tecem, nos cotidianos, histórias-experiências. Elas não ditam o que deve ser sentido; produzem, antes, sensações 
e, a partir delas, interesses podem ser discutidos. Os modos aprendentes na/da experiência rejeitam aos modelos clássicos de atuação docente "[...] habitualmente reconhecidos como desejáveis" (HOLZMEISTER; LOPES, p. 68) e conciliam conflitos para criarem mais diferenças, ao invés de reduzi-las. Criar diferença para que a diversidade não seja mais um campo recheado de preconceitos, para que o menino possa usar sapatilha e a menina possa usar sapatão. Para que a moça possa se vestir de menino e o moço possa ser menino e menina.

\section{MOVIMENTO III. PALCOS REINVENTADOS OU O MOVI- MENTO DOS PALCOS}

Um carrasco de enorme machado é chamado ao palco e, ensandecido, põe-se a cortar as amarras dos sapatinhos. Rasga-lhe o corpo e a moça pode, enfim, dançar os ritmos que quer, não mais impostos pelos sapatinhos, pelos sapatos escolares. Festejam os ritmos caóticos, nem funk, nem balé, nem bolero, nem rap, mas toda tentativa de som.

$\mathrm{Na}$ escola nossos carrascos são criados. Vocês duas o convidam. O convite ao carrasco é sempre de quem está no palco. É quem tem a possibilidade de dizer "basta" ao cansaço da dança de ritmo único. Mas vocês só poderiam fazê-lo nesse ambiente em que o palco já não é mais tão assustador, em que conseguem sentir que as outras mãos segurando o tecido fino já não mais tentam, com tanta força, arrancar-lhes de si mesmas. $\mathrm{O}$ tecido envolto nas mãos de vocês, agora, é fino e estranhamente leve.

Uma vez que as ameaças são menos intensas, vocês, enfim, 
podem apreciar o palco. Respiram menos esbaforidas. E enxergam outros tantas pessoas que poderiam usar o palco como lugar de criação de novas conversas. E propõem, então, “descer do palco".

Não há carta explicativa ou sequer dedicatória. Apenas descem do palco. As pessoas olham alarmadas quando, em algum momento, vocês não mais adentram os portões de mãos dadas. Rolam cochichos e o garoto que um dia saiu da porta direto para o corredor no primeiro dia de vocês - aquele do fim do primeiro movimento - pergunta-lhes se está tudo bem entre vocês. Ambas sorriem, mas nada explicam. Apenas dizem estar ótimas.

$\mathrm{E}$, aos poucos, outras pessoas vão se tornando as diferentes. $\mathrm{E}$, toda vez que alguém se diferencia, ela se torna uma pessoa feminina, com o primeiro direito de se diferir da imagem ideal (GUATTARI, 1985). Entre vocês duas, percorre certa admiração a cada vez que a escola percebe uma nova diferença: a surda, a cega, a moça com Down, a com altas habilidades, mas também a negra, a índia, a oriental, a moça com duas avós, com três mães, com pais israelitas, assim como quem vai a centros espíritas, a quem saúda Buda, a quem se refere às Entidades do candomblé ou mesmo quem não acredita...

De sapatilhas ou sapatões, de tênis, chinelos ou pés descalços, pessoas são convidadas (ainda que empurradas) ao palco. A este palco sempre em movimento. E, com um pouco de esforço coletivo, os palcos sempre mudam, as pessoas sempre descem para outras pessoas. Não por estarem "satisfeitas" com suas lutas! Não. Elas apenas transitam. Transpõem outras questões em outras 
conversa, fazendo surgirem, em seus problemas, problemáticas diferentes, ampliando a tensão entre as diferenças sem que elas passem a ser uma conversa vazia, cheia de clichês e falas automáticas.

A história já não é mais de vocês duas; o movimento já é da escola. É um delírio desejante da própria escola. Criação de diferenças como aposta da tal inclusão. A própria escola vira o palco.

\section{REFERÊNCIAS}

BAPTISTA, L. A. S. A atriz, o padre e a psicanalista: os amoladores de faca. Anuário do Lasp, Niterói, v. 1, n. 3/4, 1997, p. 103-109.

BEIRAS, A.; LODETTI, A.; CABRAL, A. G.; TONELI, M. J. F.; RAIMUNDO, P. Gênero e super-heróis: o traçado do corpo masculino pela norma. Rev. Psicologia e Sociedade, v. 19, n. 3, 2007, p. 62-67.

CARVALHO, J. M. O cotidiano escolar como comunidade de afetos. Petrópolis: DP et Alii; Brasília: CNPq, 2009.

FOUCAULT, M. Microfísica do poder. 27. ed. São Paulo: Graal, 2013.

GOMES, M. A. O.; FERRAÇO, C. E. Sexualidades e fabulação: sobre currículo, clichê e cotidiano escolar. In: RODIGUES, A.; BARRETO, M. A. S. C. (Orgs.). Currículos, gêneros e sexualidade: experiências misturadas e compartilhadas. Vitória: Edufes, 2013.

GUATTARI, F. Revolução molecular: pulsações políticas do desejo. Trad. Suely Rolnik. 2. ed. São Paulo: Brasiliense, 1985.

HOLZMEISTER, A. P. P.; LOPES, S. W. O currículo como corpo afe- 
tivo: aprendizagem e diferença em uma educação para potência. In: CARVALHO, Janete Magalhães. Infância em territórios curriculares. Petrópoli: DP et Alii, 2012.

NARDI, H. C. Nas bordas do humano: lutas pelo reconhecimento e capturas identitárias. In: RODIGUES, A.; DALLAPICULA, C.; FERREIRA, S. R. S. Transposições: lugares e fronteiras em sexualidade e educação. Vitória: Edufes, 2014.

PERRAULT, C. Cinderela ou o sapatinho de vidro. In: Contos de fadas: de Perrault, Grimm, Andersen \& Outros. Apresentação: Ana Maria Machado. Trad. Maria Luiza X. de A. Borges. Rio de Janeiro: Zahar, 2010.

ROSEIRO, S. Z. O Grupo CLAMP ou como sentir o feminino em mangás. In: III Seminário Nacional de Educação, Diversidade Sexual e Direitos Humanos, 2014, Vitória. Anais (eletrônicos)... . Vitória, 2014.

SILVA, S. K.; ROSEIRO, S. Z. A sexualidade compõe outros mapas escolares? In: III Seminário Nacional de Educação, Diversidade Sexual e Direitos Humanos, 2014, Vitória. Anais (eletrônicos)... . Vitória, 2014.

SCHULZ, D. Sapatinhos del Diablo. (Apresentação artística). In: III Seminário Nacional de Educação, Diversidade Sexual e Direitos Humanos. Vitória, 2014.

VIDAL, F. F.; NEULS, J. S. Literatura infantil, escola e gênero: histórias que ensinam modos de ser homem e mulher. In: $2^{\circ}$ Seminário Brasileiro de Estudos Culturais e Educação, 2006, Canoas. Anais...: educação e cultura contemporânea. ULBRA: Editora da ULBRA, 2006. 


\title{
CORPOS QUE PROVOCAM O IMAGINÁRIO CONSERVA- DOR: LÉSBICAS NA ESCOLA
}

Ana Paula Brasil

Edmar Reis Thiengo

\begin{abstract}
Agora sei não mais reclama
Pois dores são incapazes

E pobre desses rapazes

Que tentam lhe fazer feliz.

Escolha feita, inconsciente

De coração não mais roubado

Homem feliz, mulher carente

A linda rosa perdeu pro cravo.

Gugu Peixoto e Luiz Kiari
\end{abstract}

Adrienne Rich (2010) afirma que ser lésbica é não estar condicionada à heterossexualidade compulsória, pondo em xeque a obrigatoriedade de seguir o padrão sexual considerado "normal", segundo o qual os sexos opostos se relacionam. No artigo, "O que é ser lésbica?" escrito por Alldridge (2013), no Blog da Marcha Mundial das Mulheres, a definição de lésbica é: "Ser lésbica, é antes de tudo, um ato político (...). É ser revolucionária por se portar contra o padrão pré-determinado para você. [...] Ser lésbica e demonstrar isso, é remar contra a maré heteronormativa, que te julga - te culpa - te condena - te violenta - te massacra pelo simples fato de você querer exercer sua liberdade bem como 
todas as outras pessoas que o fazem diariamente".

A violência contra a mulher é uma realidade no Brasil e se aprofunda no estado do Espírito Santo. Segundo o Mapa da Violência 2015: Homicídios de Mulheres (WAISELFISZ, 2015), o Espírito Santo é o segundo colocado no ranking geral de homicídios femininos no país e o primeiro colocado no ranking de homicídios de mulheres negras. Os dados do Mapa referem-se ao ano de 2013, período no qual foram registrados oficialmente, em âmbito nacional, 9,3 homicídios a cada 100 mil mulheres. De acordo com a publicação, entre 2003 e 2013, o número de homicídios de mulheres aumentou $21 \%$ em relação aos dados anteriores, publicados em 2011 (WAISELFISZ, 2011). Conforme dados da Organização Mundial da Saúde (OMS), apresentados no Mapa, em uma avaliação envolvendo um grupo de 83 países, em 2013 foi registrada oficialmente uma média de 13 mulheres assassinadas por dia no Brasil, correspondendo a quinta maior taxa de homicídios de mulheres do mundo (WAISELFISZ, 2015).

Outro documento relevante para o campo dos estudos acerca da diversidade e dos direitos humanos é o Dossiê Violência contra as Mulheres (2015), uma iniciativa do Instituto Patrícia Galvão. De acordo com o Dossiê, em documento recente a Comissão Interamericana de Direitos Humanos (CIDH) da Organização dos Estados Americanos (OEA) considera o seguinte: "Mulheres lésbicas correm o risco particular de violência devido à misoginia e à desigualdade de gênero na sociedade.”.

O documento continua seus apontamentos por meio de seus diversos mecanismos de monitoramentos, historicamente regis- 
trados e nos informa que: "a vulnerabilidade das mulheres lésbicas a atos de violência sexual, ou de violência intrafamiliar; no entanto, é grande a subnotificação de informações sobre esses atos. Isso pode acontecer devido ao fato de muitas das formas de violência experimentadas pelas mulheres lésbicas ocorrerem em privado e serem formas intersecionais de violência. Dos 770 atos de violência (letais e não letais) contra pessoas LGBT, 55 foram contra mulheres lésbicas, ou percebidas como tais. De acordo com os dados coletados pela CIDH, as mulheres lésbicas foram vítimas de 'estupro corretivo', ou estupro para puni-las, com a intenção de 'mudar' sua orientação sexual; de espancamentos coletivos por causa de manifestação pública de afeto; de ataques com ácidos; e de entrega forçada a centros que se oferecem para 'converter' sua orientação sexual. Ainda de acordo com os dados coletados, mulheres lésbicas são desproporcionalmente afetadas pela violência exercida pelos membros de sua família. Finalmente, de acordo com o Registro de Violência da CIDH, a maior parte da violência não letal contra as mulheres lésbicas envolve casais de mulheres lésbicas atacadas em espaços públicos.".

O Dossiê apresenta ainda dados da "Liga Brasileira de Lésbicas (LBL), informando que no país estima-se que cerca de 6\% das vítimas de estupro que procuraram o Disque 100 do governo federal durante o ano de 2012 eram mulheres lésbicas. E, dentro desta estatística, havia um percentual considerável de denúncias de estupro corretivo. Entre 2012 e 2014, as mulheres lésbicas responderam por $9 \%$ de toda a procura pelo serviço. Como outras formas de violência sexual, além deste crime afetar 
a saúde física e psíquica das vítimas, atinge de modo indireto o conjunto das mulheres LBT, ao colocar o medo do estupro como um elemento presente em sua existência - o que pode limitar suas decisões e, inclusive, inibir a demonstração livre de afetividade em locais públicos." O Dossiê nos alerta para a necessidade de medidas que evitem crimes de ódio em função da condição sexual do indivíduo, motivados por preconceitos e destaca o papel da sociedade civil e Estado na adoção de medidas preventivas, além da vigilância e da cobrança por parte do poder público. (INSTITUTO PATRÍCIA GALVÃO, 2015).

O padrão heteronormativo que em geral a escola assume ao lidar com os campos da sexualidade e do gênero, promove desigualdades e exclusão, pois não permite a manifestação de possibilidades diferentes de ser e agir para os sujeitos que nela estão inseridos (LOURO, 2003).

Enquanto espaço social dialógico e conflituoso, reunindo diferentes sujeitos e diferentes modos de significação no mundo, a escola é cenário para a construção e a desconstrução de normas e regras, num processo de disputa que envolve desigualdades, opressões, contradições e enfrentamentos diversos, inclusive em relação às concepções de sexualidade e gênero. Na esteira da normatização, exige-se que o/a aluno/a se integre à cultura escolar, a partir da adequação às regras e normas, contudo, comumente os processos de elaboração destas regras e normas não contemplam efetivamente o corpo discente e acabam não sendo problematizados suficientemente com o conjunto da comunidade escolar. Portanto, subtraem-se da normatização as 
marcas de seu processo de construção cultural, político, social e histórico, de modo que seus atravessamentos por relações de poder e seu caráter autoritário, gerontocrático e excludente é automaticamente desconsiderado (BORTOLINI, 2011). Concernente a este problema da organização escolar no Brasil, o relatório das Diretrizes Nacionais para a Educação em Direitos Humanos (EDH), capítulo das Diretrizes Curriculares Nacionais para a Educação Básica: diversidade e inclusão (BRASIL, 2013) postula a ampla participação do corpo discente na esfera das decisões institucionais e pedagógicas como princípio da educação na perspectiva dos direitos humanos. "Sob a perspectiva da EDH as metodologias de ensino na educação básica devem privilegiar a participação ativa dos/as estudantes como construtores/as dos seus conhecimentos, de forma problematizadora, interativa, participativa e dialógica." (BRASIL, 2013, p. 340). Na sequência, o documento relaciona algumas formas da escola afirmar o processo participativo, entre elas, "construir normas de disciplinas e de organização da escola, com a participação direta dos/as estudantes" (BRASIL, 2013, p. 340) e "trazer para a sala de aula exemplos de discriminação e preconceitos comuns na sociedade, a partir de situação-problema e discutir formas de resolvê-las." (BRASIL, 2013, p. 340).

Nesse sentido, a inclusão de diferentes atores e o acolhimento da diversidade sexual no espaço escolar encontra fundamentação normativa nas Diretrizes Curriculares Nacionais para a Educação Básica (2013). Por outro lado, o descumprimento dos indicativos encontrados no documento acarreta, cotidianamente, 
a exclusão e a invisibilização de homossexuais no espaço escolar, alimentando a ampliação da homofobia e das opressões às minorias e estabelecendo a heteronormatividade como padrão moral socialmente valorizado. (SANTOS, 2012 e JESUS, 2013).

Diante desse quadro, à luz do padrão heteronormativo, alunas que apresentam posturas sexuais diferenciadas na escola são percebidas como "alienígenas" (RIBEIRO DE VARGAS, 2015).

A escola pública, enquanto espaço democrático em construção precisa repensar o lugar dos diferentes corpos que nela se movem. As questões de gênero estão no foco das discussões educacionais, contudo, o senso comum ainda tem definido a ação de agentes do poder público de modo conservador. $\mathrm{O}$ acompanhamento dos relatos cotidianos sobre a violência contra a população LGBT torna evidente que a escola, enquanto espaço de formação básica, deve ampliar as discussões sobre este tema. Este trabalho buscou compreender como meninas lésbicas se percebiam no ambiente escolar e como se relacionavam com docentes, demais servidores e com seus pares.

\section{METODOLOGIA}

Para problematizarmos a presença de meninas lésbicas na escola, observamos no espaço escolar e entrevistamos duas alunas que se declaravam em um relacionamento homoafetivo, relacionando-se no ambiente escolar. A pesquisa aconteceu em uma escola pública de educação básica, na região norte do Espírito Santo.

Seguindo indicação de Rizzato (2013), adotamos entrevistas 
semiestruturadas. No primeiro momento, as entrevistadas responderam às perguntas individualmente $\mathrm{e}$, em outro momento, juntas. O ponto central das entrevistas foi o relato sobre suas vivências em um espaço público, a escola. A partir de suas colocações, questões iam sendo estimuladas e resgatadas.

Esta metodologia de pesquisa promove, inevitavelmente, a interação entre o pesquisador e o ator social. De acordo com Ranci apud Rizzato (2013), as práticas do ator social (sujeito pesquisado) constituem o objeto da pesquisa, e, ao mesmo tempo, fornece informações preciosas para o pesquisador (sujeito discursivo). Consequentemente, os atores influenciam o objeto pesquisado bem como os resultados a serem obtidos. A postura assumida para a realização das entrevistas, e para sua construção, norteou-se pela discussão de Zago apud Rizzato (2013, p. 102): "respeitar princípios éticos e de objetividade na pesquisa, bem como garantir as condições que favoreçam uma melhor aproximação da realidade social estudada".

As entrevistas foram realizadas no pátio da escola, em horários vagos de aula, durante o mês de novembro de 2015 e tiveram duração aproximada de 40 minutos. Para que as entrevistadas se ambientassem, incialmente conversamos a partir de perguntas gerais sobre o tema e, posteriormente, nos aprofundamos nas questões específicas e pontuais. No primeiro momento, durante o encontro inicial, fizemos os agradecimentos pela disponibilidade das alunas e discorremos mais detalhadamente sobre a pesquisa, pela qual já haviam se interessado, demonstrando espontaneamente o desejo de participar e contribuir. Consensuado o 
uso do gravador, iniciamos o diálogo. Para preservar a identidade das alunas, seus nomes não serão revelados.

\section{RESULTADOS E DISCUSSÕES}

Elas se conheceram na escola, mas não eram da mesma turma. Iniciaram o namoro no início de 2015, sem o conhecimento das famílias. Raramente se encontram fora da escola. Eram vistas nos corredores da escola, abraçadas, de mãos dadas e, por vezes, se beijando, mas sempre escondidas dos/as disciplinários/as e somente à vista de alguns/algumas colegas ou de funcionários/as que não se "incomodavam" (termo citado por elas).

As meninas apresentam histórico de abuso sexual infantil e de tentativas de autoextermínio, repetidas vezes. Elas iniciaram relações homoafetivas na primeira infância e relatam a necessidade de orientação psicológica ou psiquiátrica, com a condição de não serem "forçadas" a mudar suas posturas ou orientação sexual. Sentem necessidade de frequentar e pertencer a alguma denominação religiosa e cristã. Ambas são de famílias evangélicas que condenam práticas lésbicas e desconhecem a relação.

No decorrer das conversas, a religião apareceu como instituição social repressora e promotora de impedimentos para o pleno respeito à diversidade sexual.

Para abordarmos a condição de namoradas na escola, entrevistamos simultaneamente as duas alunas. De acordo com elas, às vezes se isolam um pouco em função dos olhares diferenciados, mas gostam de ser um "casal na escola", principalmente por 
ter o apoio das/os amigas/os mais chegadas/os.

Sobre a reação dos/as funcionários/as da escola, ao vê-las juntas, relataram que sofrem discriminação constante.

Ao final das entrevistas elas sugeriram que a escola promova um evento para tratar o assunto com a família e dessa forma poder ajudá-las a vencer as barreiras em casa.

\section{CONSIDERAÇÕES FINAIS}

Violências contra as mulheres não escolhem orientação sexual. No período das entrevistas, houve uma manifestação de grandes proporções nas redes sociais, com o hashtag \#PrimeiroAssédio, para alertar sobre o abuso sexual de crianças. Vários foram os depoimentos de mulheres, homo ou heterossexuais, que relataram o abuso na infância, fatos muito semelhantes aos que aconteceram com as entrevistadas.

As lutas feministas têm promovido grandes avanços no sentido de igualdade de gênero, mas, ainda assim, as mulheres fazem parte das minorias que são diariamente oprimidas, desqualificadas moralmente, desvalorizadas socialmente, controladas no âmbito familiar, submetidas no âmbito religioso, discriminadas no mundo do trabalho, especificamente em função do gênero. Porém, mulheres que fogem do padrão heteronormativo ainda sofrem duplamente, tanto pela condição de mulher quanto pela orientação sexual, discrepante em relação à pedagogia sexual burguesa, cristã, patriarcal, promotora da lógica familiar tradicional e reprodutora de altíssimo grau de violência física e simbólica nos processos de sociabilidade. 
No sentido da promoção dos direitos humanos e do consequente combate a essas violências, é tarefa transversal de educadores e educadoras insistirem na tematização educacional das lutas pelo incremento dos dispositivos de democratização social, o que, de modo tácito, passa por constantes tensionamentos no ambiente escolar, sobretudo por seu caráter laico e propício ao questionamento e à experimentação. Para tanto, como indicam as Diretrizes Curriculares Nacionais, é urgente que se articule no campo educacional a efetiva formação de educadoras e educadores para a questão da diversidade e da inclusão, com vistas à equalização do tratamento dedicado a pessoas de identidade de gênero e orientações sexuais diversas e à superação do cenário muitas vezes beligerante no qual as questões e as demandas de alunas/os que se inserem na comunidade LGBT são recebidas institucionalmente por professoras/es, gestoras/es e profissionais da educação em geral.

Assim, a formação de educadoras/es é postulada pelas Diretrizes Curriculares Nacionais no sentido da democratização da escola: "Para a efetivação da educação com esses fundamentos teórico-metodológicos será necessário o enfrentamento de muitos desafios nos âmbitos legais e práticos das políticas educacionais brasileiras. Um dos maiores desafios que obstaculizam a concretização da EDH - Educação em Direitos Humanos nos sistemas de ensino é a inexistência, na formação dos/as profissionais nas diferentes áreas de conhecimento, de conteúdos e metodologias fundados nos DH e na EDH" (BRASIL, 2013, p. $341)$. 
A partir das leituras, da observação e das entrevistas que compuseram este breve trabalho, é forçoso considerar que se trata de uma carência concreta, que deve ser assumida pela gestão escolar como tarefa primordial para a promoção da igualdade no espaço educacional. "Com relação a essa preocupação há uma recomendação explícita no Documento Final da Conferência Nacional de Educação 2010 (CONAE), na área específica da Educação em Direitos Humanos, que se refere à ampliação da '[...] formação continuada dos/as profissionais da educação em todos os níveis e modalidades de ensino, de acordo com o Plano Nacional de Educação em Direitos Humanos e dos planos estaduais de Direitos Humanos, visando à difusão, em toda a comunidade escolar, de práticas pedagógicas que reconheçam e valorizem a diversidade e a democracia participativa (BRASIL, 2010, p.162).

Outra estratégia adequada para o sucesso desta empreitada histórica é ampliar a produção de pesquisas, seminários e cursos de formação para a comunidade em geral, tendo como pano de fundo a denúncia do ódio à diferença, o qual, muitas vezes disfarçadamente, persiste em circular nas instituições de ensino brasileiras.

Desse modo, esperamos que a presente comunicação não seja tomada como mero exercício acadêmico, mas, sim, como contribuição concreta para os avanços necessários no campo da educação para os direitos humanos, para a diversidade e para a inclusão. 


\section{REFERÊNCIAS}

ALLDRIDGE, C. O que é ser lésbica?.13 mar. 2013. Marcha Mundial das Mulheres. Disponível em: $<$ https://marchamulheres.wordpress. com/2013/03/13/1414/>. Acesso em 20 fev. 2016.

BORTOLINI, A. Pensando a política pública em diversidade sexual e de gênero na escola: uma experiência com análise de conteúdo in CANDAU, Vera Maria (Org.). Diferenças Culturais e Educação: construindo caminhos. Rio de Janeiro: 7 letras, 2011.

BRASIL. Ministério da Educação. Diretrizes Curriculares Nacionais para a Educação Básica: diversidade e inclusão. Organizado por Clélia Brandão Alvarenga Craveiro e Simone Medeiros. - Brasília: Conselho Nacional de Educação: Ministério da Educação, Secretaria de Educação Continuada, Alfabetização, Diversidade e Inclusão, 2013. $480 \mathrm{p}$.

Dossiê Violência contra mulheres lésbicas, bis e trans. [s.n.t.]. Disponível em: <http://www.agenciapatriciagalvao.org.br/dossie/violencias/ violencia-contra-mulheres-lesbicas-bis-e-trans/>. Acesso em 20 fev. 2016.

JESUS, J. G. O conceito de heterocentrismo: um conjunto de crenças enviesadas e sua permanência. Psico USF, Itatiba, v.18 n.3, 2013. Disponível em: <http://www.scielo.br/scielo.php?pi$\mathrm{d}=\mathrm{S} 1413-82712013000300003 \&$ script $=$ sci_arttext $>$. Acesso em 20 set. 2015.

LOURO, G. L. Corpo, gênero e sexualidade: um debate contemporâneo na educação. Petrópolis: Vozes, 2003.

RICH, A. Heterossexualidade compulsória e existência lésbica. Bagoas, Natal v. 4, n. 5, 2010. Disponível em: <http://www.cchla.ufrn.br/ bagoas/v04n05art01_rich.pdf>. Acesso em 20 fev. 2016.

RIZZATO, L. K. Percepções de professores/as sobre gênero, sexua- 
lidade e homofobia: pensando a formação continuada a partir de relatos da prática docente. 2013. 278 f. Dissertação (Mestrado em Educação) - Programa de Pós-Graduação em Educação da Faculdade de Educação da Universidade de São Paulo, Universidade de São Pau1o, São Paulo, 2013. Disponível em: <http://www.teses.usp.br/teses/ disponiveis/48/48134/tde-23102013-112910/pt-br.php>. Acesso em 22 set. 2015.

SANTOS V. Homossexualidade no ambiente escolar. LENPES - PIBID de Ciências Sociais - UEL, [s.n.t.], v.1 n. 2, 2012. Disponível em: $<$ http://www.uel.br/revistas/lenpes-pibid/pages/arquivos/2\%20Edicao/ VANESSA\%20SANTOS\%20-\%20ORIENT.\%20CESAR.pdf $>$. Acesso em 20 set. 2015.

VARGAS, J. R. O que ouço me conduz e me produz? A constituição de feminilidades de jovens contemporâneas no espaço escolar da periferia. Porto Alegre, 2015.194 f. Tese (Doutorado em Educação) - Programa de Pós-Graduação em Educação. Universidade Federal do Rio Grande do Sul. Faculdade de Educação. Porto Alegre, 2015. Disponível em: <http://www.lume.ufrgs.br/bitstream/handle/10183/115726/000965122.pdf?sequence=1>. Acesso em 22 set. 2015.

WAISELFISZ, J. J. Mapa da violência 2015: homicídio de mulheres no Brasil. Brasília. [s.n.t.]. 2015. Disponível em: <http://www.mapadaviolencia.org.br/pdf2015/MapaViolencia_2015_mulheres.pdf $>$. Acesso em 20 fev. 2016.

WAISELFISZ, J. J. Mapa da Violência 2012 Os Novos Padrões da Violência Homicida no Brasil. São Paulo [s.n.t.]. 2011. Disponível em: <http:/www.mapadaviolencia.org.br/pdf2012/mapa2012_web. pdf $>$. Acesso em 20 fev. 2016. 


\title{
O CORPO ESTRANHO NA ESCOLA: CONSIDERAÇÕES SOBRE A REGULAÇÃO DA SEXUALIDADE NO CONTEXTO ESCOLAR
}

\author{
Guilherme Augusto Maciel Ribeiro \\ Brenda Odete Pfeifer de Araújo \\ Edmar Reis Thiengo
}

A Igreja diz: o corpo é uma culpa.

A ciência diz: o corpo é uma máquina.

A publicidade diz: o corpo é um negócio.

O corpo diz: eu sou uma festa.

Eduardo Galeano

O corpo, além de um atributo biológico em sua constituição gênica, estrutural e fisiológica é, também, resultado de um conjunto variado de significações, sejam elas culturais, históricas, políticas ou ideológicas que definem as identidades dos sujeitos. Não obstante, a sexualidade, fenômeno intrinsecamente ligado à biologia do corpo, acompanha esta complexa rede de significações construídas historicamente pela cultura, em determinado espaço/ tempo. Em Weeks (2010), a relação dialógica entre corpo e sexualidade deve ser compreendida dentro de um:

[...] contexto histórico específico, explorando as condições historicamente variáveis que dão origem à importância atribuída à sexualidade num momento particular e apreendendo as várias relações de poder que modelam o que vem a ser visto 
como comportamento normal ou anormal, aceitável ou inaceitável (WEEKS, 2010, p. 43).

Assim, o corpo deixa de ser um objeto exclusivamente biológico, determinado e passa a ser entendido, também, como fruto das relações estabelecidas socialmente em um recorte temporal específico, adquirindo características próprias e dinâmicas, sobretudo naquilo que se atribui socialmente como possibilidades naturais e/ou proibições de suas explorações: os dispositivos históricos da sexualidade (FOUCAULT, 1993, p. 244).

Ontologicamente, a concepção de corpo sexual é pautada no binarismo de gênero masculino versus feminino, gerando uma valorização aos aspectos sexuais anatômicos enquanto entidade de validação das identidades, relegando ao sexo biológico a determinação de padrões socialmente aceitos como "normais" para exploração da sexualidade. Contudo, o corpo assume configurações políticas, isto é, ele se molda às imposições sociais e culturais que em Foucault (1998), se firmam como dispositivos de poder, construídos historicamente por meio de práticas discursivas que instituem saberes e legitimam os próprios poderes regulatórios então criados, que moldam os códigos identitários de gênero baseados na diferença sexual e na construção de seres binários homem ou mulher.

O controle da sociedade sobre os indivíduos não se opera simplesmente pela consciência ou pela ideologia, mas começa no corpo, com o corpo. Foi no biológico, no somático, no corporal que, antes de tudo, investiu a sociedade capitalista. $\mathrm{O}$ corpo é uma realidade bio-política. (FOUCAULT, 
É no ato da bio-política que correm incursões sobre a regulação da sexualidade. O mesmo é compartilhado por Bourdier (1999), quando sugere que o corpo sexualizado representa um depositório de princípios e visões de mundo, capazes de naturalizar a diferença socialmente naturalizada entre ser homem e ser mulher. Em contrapartida, na medida em que se assume uma concepção pós-modernista, há que se pensar numa relativização entre as conotações depreendidas de corporeidade, sexualidade e gênero. Nos estudos de Butler (2003), continua a problematização sobre o corpo, o gênero e sexualidade. Para a autora:

[...] se o gênero são os significados culturais assumidos pelo corpo sexuado, não se pode dizer que ele decorra, de um sexo desta ou daquela maneira. Levada a seu limite lógico, a distinção sexo/ gênero sugere uma descontinuidade radical entre corpos sexuados e gêneros culturalmente construídos. Supondo por um momento a estabilidade do sexo binário, não decorre daí que a construção de "homens" aplique -se exclusivamente a corpos masculinos, ou que o termo "mulheres" interprete somente corpos femininos. Além disso, mesmo que os sexos pareçam não problematicamente binários em sua morfologia e constituição (ao que será questionado), não há razão para supor que os gêneros também devam permanecer em número dois (BUTLER, 2003, p. 26).

Simone de Beauvoir, em seu célebre livro O Segundo Sexo (1967), abre uma séria discussão sobre o controle disciplinar dos corpos, tangenciando suas considerações sobre as construções so- 
ciais de gênero que engendram posturas socialmente desejáveis $e$ às especificidades masculinas ou femininas. Em suas críticas a este modelo regulatório e hegemônico, salienta que:

\begin{abstract}
Ninguém nasce mulher: torna-se mulher. Nenhum destino biológico, psíquico, econômico define a forma que a fêmea humana assume no seio da sociedade; é o conjunto da civilização que elabora esse produto intermediário entre o macho e o castrado que qualificam de feminino. Somente a mediação de outrem pode constituir um indivíduo como um outro (BEAUVOIR, 1967, p. 09).
\end{abstract}

A padronização e hegemonização dos corpos também são discutidas por Louro (2000), ao salientar que essas concepções socialmente construídas são reproduzidas nas relações e processos concebidos na escola. Para a autora, a preocupação com o corpo também perpassa o contexto da educação formal, subsidiando o engendramento dos processos, as estratégias e práticas pedagógicas. Nas palavras da autora "Todos os processos de escolarização sempre estiveram - e ainda estão - preocupados em vigiar, controlar, modelar, corrigir, construir os corpos de meninos e meninas, de jovens homens e mulheres" (LOURO, 2000, p. 60).

Prosseguindo com a reflexão, em Louro (2010) é possível encontrar registros teóricos sobre a flexibilização sexual dos corpos. Em seu entendimento há muitas formas de fazer-se mulher ou homem, assim como há várias possibilidades de viver prazeres e desejos corporais. Mas, atenta para o fato de que, quase sempre, estas ações são sugeridas, anunciadas, promovidas socialmente e que, também, são renovadamente, reguladas, condenadas ou ne- 
gadas.

Diante deste breve recorte teórico, torna-se evidente o modo como as convenções sociais disciplinam a fruição do corpo, configurando-se como dispositivos de regulação identitária dos corpos e da sexualidade. Obedecendo a padrões sociais estabelecidos por uma visão hegemônica politicamente institucionalizada, este engedramento é capaz não apenas de coibir a livre expressividade do corpo em suas mais amplas possibilidades. Em Bauman (2001) encontramos um contraponto a esta perspectiva relacional estática; para ele vivemos em sociedade global cuja dinâmica existencial assume contornos fluidos, líquidos, o que conceitua como "modernidade líquida". A modernidade proposta nesta análise enseja uma transitoriedade de valores, que constantemente confrontam e suplantam os velhos que, em seguida perderá o seu lugar a outros, indefinidamente. Esta constante, e veloz, mutação de padrões e valores acarreta nas nossas decisões diárias, na maneira de dialogarmos com o mundo.

Considerando a fugacidade das relações humanas, é necessário destacar que o mesmo não ocorre com o entendimento do corpo. Este é compreendido como objeto sexualizado, portador de um repertório de ações comportamentalmente demarcadas pela aceitação social normativa que, nestes moldes, assume e incute à sexualidade o preceito biologizador do desejo: a heteronormatividade como paradigma sócio-cultural institucionalizado para a vida em sociedade. Qualquer outra sinonímia é falseada por este construto político- ideológico que, 
retomando as teorizações foucaultianas, suscita o controle e a regulação social do corpo e da sexualidade.

\section{A REGULAÇÃO SOCIAL DO CORPO E DA SEXUALIDA- DE NO CONTEXTO ESCOLAR}

Os dispositivos de regulação da sexualidade na escola ancoram-se nas múltiplas esferas de seu contexto pedagógico. As intervenientes sociais, políticas, culturais e históricas se estabelecem e se entrelaçam institucionalizando como padrões normativos a serem desempenhados no complexo processo de ensino-aprendizagem. Não obstante, torna-se um fator de poder na medida em que sua naturalização se legitima na prática do currículo escolar e, paralelamente, na vivência obscura de um currículo oculto.

\footnotetext{
Na escola, o currículo, as disciplinas, as normas regimentais, as formas de avaliação, os materiais didáticos, a linguagem, constituem-se em instâncias que refletem e produzem as desigualdades de gênero, de sexo, de raça, etc., e podem incentivar o preconceito, a discriminação, o sexismo (FURLANI, 2003, p. 69).
}

Embora um espaço de pluralidade, o ambiente escolar reproduz padrões socialmente desejados, incluindo a negação ao que for dissonante às convenções formais estabelecidas por seus agentes. Neste contexto, a polissemia que compõe o espaço escolar pode revelar a intolerância, o preconceito e a exclusão de uma parcela marginalizada socialmente por não se inserir no modelo proposto pela maioria, sobretudo quando se trata das relações de gênero e de sexualidade. Para além disso, 
[...] em uma sociedade que privilegia o padrão heteronormativo enquanto entidade de manifestação de sua sexualidade, ter uma opção sexual divergente a este perfil implica em enfrentar as asperezas de uma condição transgressora, já que poucas são as ocasiões onde a diversidade sexual encontra espaço para o diálogo, a reflexão e o debate nos ambientes formais de aprendizagem (RIBEIRO, 2015, p. 69).

Em uma outra percepção, destaca-se que, na vivência escolar, são reconhecidas práticas que desprestigiam e invisibilizam as diversidades sexuais e de gênero. Estas se inscrevem ao que Fernandes e Pereira (2013, p. 66) denominam de "pedagogia do silenciamento", no qual o diferente não merece ter os mesmos espaços democráticos de inserção à educação, ou quando os possui, são demarcados como desviante, reforçando a demarcação de espaços e posturas impostas para o convívio normal em sociedade. Os autores esclarecem ainda que, "o silêncio emudece os sujeitos envolvidos no processo educativo, pois suas vozes tornam-se abafadas, suas identidades tornam-se invisíveis e suas práticas afetivo-sexuais amputadas, deslocadas" (FERNANDES; PEREIRA, 2013, p. 66).

Numa tentativa de possibilitar uma reflexão crítica sobre a regulação social da sexualidade, sua visibilidade e não silenciamento nos ambientes escolares, propomos, neste momento, basear nossas discussões no estudo das percepções de alunos e funcionários da instituição de ensino, a partir da inserção de um "corpo estranho" neste ambiente formal de ensino. concepção de 
"corpo estranho" adotada para esta análise se refere a um sujeito de sexo masculino trajando uma vestimenta socialmente identificada como feminina (uma saia longa, estilo hippie), transitando livremente pelos corredores do Instituto em estudo. Este ator será discretamente acompanhado por cinco observadores, distribuídos pelos espaços internos do Instituto, responsáveis por descrever suas considerações sobre as diversas reações (corporais e comportamentais) explicitadas por todos os sujeitos que a ali se faziam presentes.

O Ifes/Vitória ${ }^{1}$ é reconhecido pela tradição de oferecer à população cursos de formação profissional tecnológica em áreas socialmente consideradas como espaços de domínio masculino . Por esse motivo, essa instituição foi selecionada para a realização de uma investigação pautada na observação da receptividade de alunos e funcionários com um corpo que representa uma sexualidade dissidente dentro deste contexto escolar. Procurou-se registrar em diários de bordo as situações que revelaram manifestações de estranhamento e/ou intolerância em relação ao objeto estudado.

O desconforto e preocupação gerados por esta proposta ensejou um discurso de insegurança por parte dos sujeitos convidados para a observação:

"Inicialmente, fiquei com um pouco de receio, pois tra-

\footnotetext{
1 Tal observação é feita com base na oferta de cursos que, predominantemente, são mais procurados por alunos do sexo masculino, o que faz alusão a divisão sexual do trabalho, encerrando o feminino a uma vida domiciliar, privada. “[...] Aos homens o cérebro, a inteligência, a razão lúcida, a capacidade de decisão; às mulheres, o coração, a sensibilidade, os sentimentos" (PERROT, 1988, p. 177)
} 
balho na instituição, e com um pouco de medo dele sofrer alguma desmoralização ou assédio diante de sua vestimenta".

Denota-se, neste discurso, que a naturalização da diferença e suas sanções morais, físicas e psicológicas em razão da manifestação de uma sexualidade dissonante àquela heteronormativa (BUTLER, 2003), parecem bastante nítidas neste ambiente. De certo modo, a masculinização deste espaço favorece a noção da institucionalização sexual dos corpos e de suas condutas, corroborando para sua docilização em função de um suposto padrão heteronormativo implícito a uma conduta social e, nesta ocasião, uma conduta social escolar.

Embora a liberdade que cada um de nós temos nos permita gozar publicamente de nossos direitos, o mesmo não ocorre para aqueles que não demonstram o mesmo padrão social normativo de gênero e sexualidade. A regulação da sexualidade, direta ou indireta, passou a ser algo implícito às práticas sociais, o que ficou evidente no seguinte relato de um dos observadores:

"Nos posicionamos em alguns locais no pátio principal e quando ele chegou na portaria, uma das pessoas responsáveis por conferir a carteirinha do aluno, conferiu mais detalhadamente e, em seguida o liberou. Fiquei por um tempo na portaria para tentar ouvir algum comentário que se referisse a ele. Um dos seguranças comentou que já estava virando moda homem utilizar saia no Ifes, e uma das recepcionistas comentou ironicamente 'estampa bonita não?', com uma colega. Um outro homem 
comentou que era por causa do calor que fazia. "

"[...] a princípio, não desperta muita atenção dos alunos e funcionários da instituição. Porém, ao passar pelo pátio, o ator da pesquisa começa a atrair olhares e pequenos comentários. Estes, em sua maioria, partiram dos alunos. Percebi que foram palavras rápidas seguidas de pequenos sorrisos, que, na maioria das vezes, eram em tom de ironia."

"No local (cantina), ficaram perceptiveis os comentários e pequenos atos de deboche e ironias. Uma aluna pegou seu celular e tirou uma foto do nosso colega e disse: Essa daqui vou mandar para ofulano ver."

A busca por respostas que deslegitimam o "estranho" em detrimento ao dito "normal" são recorrentes nos mais diversos discursos. Primeiro, pois por meio da identificação do estranho buscam-se elementos regulatórios capazes de justificar a diferença. Ato de conferir "mais detalhadamente" as credenciais daquele dissidente que ousa adentrar um espaço patriarcal ${ }^{2}$ demonstra o não-lugar deste sujeito neste ambiente. Talvez isso explique uma maior dedicação à análise das credenciais do sujeito dissidente.

Os comentários feitos pelos funcionários evidenciam outras peculiaridades que merecem atenção. A ironia presente

2 Termo empregado para reforçar a divisão sexual do trabalho e as distinções de gênero entre homens e mulheres, destacando-se a superioridade masculina e seu domínio público, e a inferiorida e fragilidade feminina, seu papel biológico de reprodução e sua posição privada, no ambiente doméstico (CASTELLS, 2002). 
nos discursos sinaliza o desconforto trazido pela situação: um homem trajando uma saia no Ifes/Vitória, além incomum, denota, de certo modo, uma afronta aos costumes "normais" praticados em sociedade. O tom de ironia aclarado é uma tentativa de retificar a diferença de modo sutil, velado: um eufemismo para as considerações entorno das diversidades sexuais e de gênero e de suas manifestações. Os observadores ainda atentam em suas considerações, que:

"Me parece que eles procuram encontrar alguma pessoa que compartilhe da mesma ideia que eles para então darem prosseguimento nos comentários."

Somente quando há uma consensualização nos ditos e nos olhares sobre o outro é que a ironia nos comentários ganha força, embora não fossem explícitas formas coercitivas de preconceito, discriminação ou violência. De volta ao pátio interno do Ifes/ Vitória, o estranhamento prosseguiu. No relato dos observadores,

"Ficamos um tempo no pátio principal da instituição, por ali haver uma grande movimentação de pessoas. Havia alguns alunos sentados no chão e os olhares não eram indiferentes à situação. As pessoas olhavam para a saia e, em seguida, olhavam para o rosto, para confirmar se estavam realmente presenciando um homem de saia."

Concordamos com Cassal et al (2011, p. 466), quando 
argumenta que o controle social do corpo e da sexualidade, a anatomo-política, se constitui por estratégias de docilização do corpo e controle de suas potências, através de um minucioso domínio de seu funcionamento e de suas capacidades; este dispositivo relaciona-se a instituições de captura, podendo estas ser estabelecimentos formais - como prisões, fábricas, abrigos e escolas - ou modos de funcionamento. $\mathrm{O}$ olhar regulatório se torna imperioso sobre os "corpos estranhos", e permanece constante nos mais variados ambientes deste Instituto Federal:

"Na cantina, nos sentamos numa mesa e lá havia um grupo de alunos de um curso superior. Não sei se por não conseguirem disfarçar ou se por quererem chamar atenção, eles riam entre si e uma das alunas dirigiu a palavra a um outro aluno, dizendo que queria ser homem para ver como era e que ela tinha curiosidade de ser homem por um dia."

A curiosidade sobre os prazeres dissidentes ${ }^{3}$ pode despertar reações diversas em cada sujeito: o reconhecimento, a desconfiança, o desejo, a empatia... Porém, de todas essas tipificações emocionais reativas, uma parece ser a mais comum: o riso. É com este artifício que o estranhamento se torna velado. Rir parece ser um subterfúgio para o não-lugar do diferente. E ele se repetiu em todas as situações, disfarçando, silenciando e obscurecendo a reação natural diante do diferente: a rejeição daquilo que foge à norma (à qual norma?).

3 Conferir DÍAZ-BENÍTEZ, María Elvira; FIGARI, Carlos Eduardo (Orgs.). Prazeres dissidentes. Rio de Janeiro: Garamond, 2009. 
"Na biblioteca, ele subiu as escadas e fiquei aguardando que ele saísse para eu realizar as observações. Uma funcionária da biblioteca estava ao lado de um senhor (que também é servidor) que me chamou e perguntou se eu o conhecia. Disse que sim, que era da minha sala de mestrado e, então, o senhor me perguntou se a saia era da cultura dele. Disse que não, mas ele me perguntou, 'ele não é de outro país não? Da Escócia'. Eu disse que não. A outra funcionária riu e o senhor disse para ela que não poderia rir."

Assim, os grilhões que determinam as territorialidades ${ }^{4} \mathrm{e}$ especificações relativas à sexualidade, aquilo que é permitido ou não ao masculino e ao feminino, produzem marcas, explícitas ou veladas, que são inscritas em nossas histórias pessoais, e postas em ação pelas instituições reguladoras - escola, mídia, igreja, lei (LOURO, 2010). Atribuir a uma outra nacionalidade o estranhamento pela vestimenta trajada pelo corpo "estranho" parece ser uma alternativa viável para justificar as sansões sociais pela performance de sexualidade dissidente.

Em cada espaço, em qualquer momento, a diferença é questionada. Mais do que isso, ela é relativizada à norma imposta pela sociedade. Fugir à norma seria transgredir a ordem social vigente. Seria. O empoderamento a que defendem Freire e Shor

4 O entendimento de territorialidades propostas para esta análise é uma construção conceitual produzida com intuito de problematizar a rigidez a que se vislumbra a sexualidade na pós-modernidade. Conferir DELEUZE, G. e GUATTARI, F. s/d. O Anti-Édipo: capitalismo e esquizofrenia. Lisboa: Assírio \& Alvim, 1972. 
(1986), implica conquista da liberdade, e é neste sentido que a busca pelo reconhecimento, visibilidade e lugar na sociedade tornam-se elementos políticos de avanço e de superação do estado de subordinação e inferioridade a que são submetidos os marginalizados, sobretudo aqueles que são excluídos por sua identidade sexual e de gênero não normativos. Transgredir deixa de ser um objeto de deslegitimação das verdades impostas e passa a ser um instrumento de (re)conhecimento e de (sobre)vivência em uma sociedade excludente.

\section{À GUISA DE CONCLUSÕES:}

O corpo é palco de inúmeras determinações biológicas, sociais, culturais historicamente construídas pela sociedade. Mantê-lo sob a égide das determinações institucionalizadas, parece a condição para ser reconhecido como pertencente a tal grupo. $\mathrm{O}$ que causa estranhamento deve ser analisado, observado e sancionado, de acordo com as normas, impostas, prescritas ou simplesmente convencionadas.

Quando adentra a escola, o corpo ainda sofre com a reprodução dos padrões socialmente desejados, incluindo a negação ao que for dissonante às convenções formais estabelecidas por seus agentes. Em uma sociedade que privilegia o padrão heteronormativo enquanto entidade de manifestação de sua sexualidade, apresentar uma performance sexual divergente a este padrão implica em enfrentar as asperezas de uma condição transgressora. O "estranho", mais do que ser um corpo diferente, revela o modo como a sexualidade é regulada por dispositivos biopolíticos soci- 
ais. Predominantemente relegado a um não-lugar, o "corpo estranho" sofre com sansões de sua liberdade: o preconceito, explícito ou velado.

O tradicionalismo com que a corporeidade está inserida reforça a não aceitação do diferente, no tocante à polissemia com que gênero e sexualidade se apresentam na sociedade. Tais ações sinalizam para a manutenção das relações de gênero vigentes, ainda circunscritas numa complexa rede de significações centradas no patriarcado. Destarte, as regulações sociais de sexualidade institucionalizadas adentram os espaços escolares, reforçando as divisões sexuais e os espaços/comportamentos a serem ocupados por homens e mulheres.

Além disso, qualquer transgressão a esta lógica binária é rejeitada, sugerindo que as experiências múltiplas da sexualidade (e de gênero), quando praticadas fora de seu lugar comum, são objeto de observação réproba de sujeitos sociais que por eles transitam, a nos mostrar o quanto ainda precisamos avançar nas discussões sobre esta temática.

\section{REFERÊNCIAS}

BAUMAN, Z. Modernidade Líquida. Rio de Janeiro: Jorge Zahar, 2001.

BEAUVOIR, S. O Segundo Sexo. $2^{\text {a }}$ ed. vol. 2. São Paulo: Difusão Europeia do Livro, 1967.

BOURDIEU, P. A dominação masculina. Rio de Janeiro: Bertrand Brasil, 1999. 
BUTLER, Judith. Problemas de Gênero: feminismo e subversão da identidade. Rio de Janeiro: Civilização Brasileira, 2003.

CASSAL, L. C. B; Gonzalez, A. M. G.; Bicalho, P. P. G. Psicologia e o dispositivo da sexualidade: biopolítica, identidades e processos de criminalização. In: Psico, Porto Alegre, PUCRS, v. 42, n. 4, pp. 465473, out./dez. 2011.

CASTELLS, M. O poder da identidade. São Paulo: Editora Paz e Terra, 2003.

CAVALCANTI, D. R. M. O Surgimento do Conceito de Corpo: Implicações da modernidade e do individualismo. In: CAOS - Revista Eletrônica de Ciências Sociais, n.9, set./ 2005, p.53-60.

FERNANDES, C. F.; PEREIRA, A. L. P. Sexualidades em trânsito: juventudes "desviantes" na escola. In: Revista Ícone: Revista de Divulgação Científica em Língua Portuguesa, Linguística e Literatura. v. 11. jan. 2013. P. 61-69.

FOUCAULT, M.. Microfísica do poder. $11^{\mathrm{a}}$ ed. Rio de Janeiro: Graal, 1993.

. Scientia Sexualis. In: . História da sexualidade: a vontade do saber. 10. ed. Rio de Janeiro: Graal, 1998. v. 1, cap. 3, p. 53- 78.

FREIRE, P. Conscientização. Teoria e prática da libertação: uma introdução ao pensamento de Paulo Freire. São Paulo, SP: Centauro, 2001.

FREIRE, P. ; SHOR, I. Medo e ousadia - o cotidiano do professor. Rio de Janeiro: Paz e Terra, 1986.

FURLANI, J. Educação sexual: possibilidades didáticas. In: LOURO, G.L., NECKEL, J.F.; GOELLNER, S. V. (Orgs.). Corpo, Gênero e Sexualidade: um debate contemporâneo na educação. Petrópolis: Editora Vozes, 2003. 
LOURO, G. L. Pedagogias da Sexualidade. . In: LOURO, Guacira Lopes (Org.). O corpo educado: pedagogias da sexualidade. Belo Horizonte: Autêntica Editora, 2010.

. Corpo, escola e identidade. In: Educação \& realidade. Porto Alegre, v. 25, n. 2, 2000.

PERROT, M. Os excluídos da história: operários, mulheres e prisioneiros. Rio de Janeiro: Paz e Terra, 1988.

RIBEIRO, G. A. M. et al. Percepção de gênero e identidade de gênero no ambiente escolar: uma possibilidade reflexivo-pedagógica na educação e jovens e adultos - PROJOVEM. In: CAMPOS. C.R.P (Org.). Gênero e diversidade na escola: práticas pedagógicas e reflexões necessárias. Vitória: Ifes, 2015. Série pesquisas em educação em ciências e matemática; vol.5. p. 69-88.

WEEKS, J. O Corpo e a Sexualidade. In: LOURO, Guacira Lopes (Org.). O corpo educado: pedagogias da sexualidade. Belo Horizonte: Autêntica Editora, 2010. 


\title{
EDUCAÇÃO E DIVERSIDADE RELIGIOSA: POR UM AMBIENTE RESPEITOSO E DIALÉTICO
}

\author{
Flávio Lopes dos Santos \\ Robson Vinicius Cordeiro
}

Edmar Reis Thiengo

Deus não tem religião.

Mahatma Gandhi

A construção de uma educação inclusiva passa, necessariamente, pelo reconhecimento da diversidade entre os sujeitos em seus múltiplos aspectos, bem como pela preservação e respeito a essa multiplicidade na busca pela garantia de cada indivíduo ser e expressar sua singularidade sem sofrer qualquer forma de violência. Nesse sentido, o conceito "inclusão" colocase como um desafio paradigmático para a sociedade, na medida em que solicita reflexões profundas e ações diferenciadas que provoquem uma metamorfose social capaz de romper com as estruturas rígidas e os hábitos historicamente constituídos que só reforçam a superioridade de uns e a situação de exclusão de tantos.

A reflexão aqui delineada não nos transporta a um terreno pacífico, mas, ao contrário, coloca-nos diante de um poderoso embate entre a proposição de um novo paradigma social e o que 
já se encontra cimentado e protegido pelas estruturas políticas, econômicas e sociais vigentes. Abrir-se a um novo paradigma social é uma atitude revolucionária, pois significa compactuar com a mudança de tal maneira que se abre mão de uma formatação social, colocando-a em estado de análise e reformulação, o que não representa algo simples e imediato, mas é um processo gradual e carregado de complexidade. Tudo, a princípio, perde a segurança que a rigidez do hábito the havia constituído. Vivencia-se um mal-estar, produto da estranheza com aquilo que ainda não se havia pensado ou experimentado, até que pontuais reflexões e pequenas ações começam a surgir representando o alvorecer, mesmo que abafado pelo já existente, de uma nova organização societária.

A inclusão, nessa perspectiva, se configura como um paradigma social ao solicitar que a sociedade reformule-se tendo como princípio fundamental, como aponta Mesquita (2007), o acolhimento, entrelaçado com o respeito às diferenças e reforçado pelo anseio recíproco entre os pares para o estabelecimento do exercício da cidadania de forma digna, igualitária e democrática.

A escola, por sua vez, quando extrapola o domínio e a base reprodutivista que sustenta as estruturas que vigoram na sociedade e estabelece uma postura crítica e reflexiva do meio em que está inserida, materializa-se como um terreno fértil para a consolidação de novos paradigmas, haja vista que ali se encontram novos cidadãos em formação, ainda abertos a novas experiências de mundo e configuração social. Dessa maneira, no final do século XX, políticas sociais e educacionais, segundo Mesquita (2007), 
vêm afirmando o paradigma da inclusão ao propor reformulações na organização da educação básica, alterando as estruturas físicas dos espaços escolares, passando pelo currículo estabelecido e inserindo-se, mesmo que minimamente, nos processos formativos dos docentes.

Dessa forma, corroborando com Mesquita (2007), a educação inclusiva configura-se como um meio para a transformação da sociedade, tendo em vista que a escola se realiza na sua condição contraditória entre reprodução e transformação, e é "seu caráter transformador [que] tem sido retoricamente reforçado em encontros mundiais e internacionais, que objetivam deliberar propostas de acolhimento da diferença" (MESQUITA, 2007, p. 38-39).

Coloca-se aqui a necessidade de ressignificação conceitual para que a construção de uma sociedade, que reflita um paradigma inclusivo, se concretize. São reformulações socioculturais que visam suplantar impedimentos arquitetônicos, conceituais, atitudinais e procedimentais, isso significa que não é só reformar espaços físicos para que garantam a acessibilidade de pessoas com deficiências a locais antes inacessíveis, mas promover, também, o entendimento de que a diversidade é uma realidade e a melhor formar de lidar com ela é pelo respeito. São reformulações que precisam superar o plano teórico com urgência e encontrar apreço em práticas humanizadas.

Segundo Mantoan (2005), a Constituição Federal, já em 1988, assegurava o direito de ser diferente nas escolas ao estabelecer um de seus princípios, no artigo 206, inciso I, a igualdade 
de acesso e permanência. Tal indicação só confirma a escolha fundamental pela cidadania e pela dignidade da pessoa humana, expressa no artigo $1^{\circ}$, incisos II e II, e corrobora um de seus objetivos fundantes: "promover o bem de todos, sem preconceitos de origem, raça, sexo, cor, idade e quaisquer outras formas de discriminação" (art. $3^{\circ}$, inciso IV). Essa formulação legislativa já comunicava o que em 1994, a Declaração de Salamanca (UNESCO, 1994, p. 3) preceituou:

[...] todas as escolas deveriam acomodar todas as crianças, independentemente de suas condições físicas, intelectuais, sociais, emocionais, lingüísticas ou outras. Deveriam incluir todas as crianças deficientes e superdotadas, crianças de rua e que trabalham, crianças de origem remota ou de população nômade, crianças pertencentes a minorias lingüísticas, étnicas, ou culturais e crianças de outros grupos em desvantagem ou marginalizados. As escolas têm que encontrar a maneira de educar com êxito todas as crianças, inclusive as que têm deficiências grave.

Se tomarmos por referência esses dois dispositivos legais, podemos pensar a inclusão como um movimento amplo que abarca todas as pessoas em sua singularidade. No entanto, a executividade desses dispositivos nos lança já referida discussão entre o ideal e o real, entre o plano teórico e o prático. A própria Declaração de Salamanca, ao utilizar o verbo dever conjugado no futuro do pretérito, indica a necessidade de condições determinantes para a realização do que foi estabelecido em seu texto. Torna-se uma sugestão ou um pedido aos poderes do Estado para 
que possibilitem sua efetivação.

Ainda que sob o aspecto propositivo, a Declaração de Salamanca é um marco para a orientação inclusiva, sobretudo nas escolas comuns, compreendidas como um meio eficaz para combater ações discriminatórias, produzindo comunidades acolhedoras, capazes de transformar a sociedade por meio da inclusão e do respeito a toda a pessoa humana em sua singularidade e dignidade. A inclusão, nesse sentido, é um produto de uma série de transformações estruturais e indissociáveis nos prédios e espaços comuns, nos currículos, métodos, conceitos e significações, nas formações e nas atitudes dos professores e demais membros do corpo escolar. É "um pretexto para que a escola se modernize, atendendo às exigências de uma sociedade que não admite preconceitos, discriminação, barreiras entre seres, povos, culturas" (MANTOAN, 1999, p. 23).

Compreendendo, dessa forma, a abrangência do conceito de inclusão e sua relação com a diversidade nas suas múltiplas configurações, este texto apresenta uma análise acerca da diversidade religiosa na escola, sob a perspectiva inclusiva, tomando como referência os aspectos históricos e sociais, os aspectos legais e os direcionamentos curriculares para o trato pedagógico com as questões concernentes a essa temática. Complementando tal análise, discorreremos também sobre a configuração, a abordagem e as controvérsias que existem em torno do Ensino Religioso e as possibilidades de tornar, tal disciplina, em um espaço-tempo onde se exercite respeito à diversidade de credo, de pensamento e de expressão, refletindo a experiência inclusiva no 
ambiente escolar.

\section{ASPECTOS GERAIS SOBRE A RELIGIÃO}

Muitos são os fatores que determinam a forma como ser humano vive e se relaciona com outros e com a natureza: a constituição histórica do grupo social; as variadas formas de linguagem e expressão simbólica; as crenças e hábitos instituídos coletivamente e historicamente; o movimento e a inércia econômica e política da sociedade; as tradições religiosas; são alguns dos aspectos que organizam a maneira como a sociedade se constitui, como interpreta o mundo, como estabelece sua moral e sua ética, como define as posturas de seus integrantes, como regula as relações entre os sujeitos e o ambiente, enfim, como se vive socialmente.

Dentre esses múltiplos fatores, sublinhamos as tradições religiosas, as instituições que as organizam - quando assim se fazem presentes - e o universo de crenças e técnicas que as circundam, tendo em vista a grande relevância que esses sistemas simbólicos possuem na formação do sujeito e dos grupos sociais. A via do pensamento religioso é uma das muitas formas com que o sujeito se depara no processo de construção e apropriação simbólica do mundo, estabelecendo, por exemplo, parâmetros morais que determinam a maneira de se portar e agir diante da realidade.

Para Abbagnano (2007, p. 977), a religião consiste na "crença na garantia sobrenatural de salvação, e técnicas destinadas a obter e conservar essa garantia”. Nessa definição, destacam-se dois elementos: crença como atitude religiosa fundamental, tendo 
como sustentáculo o relacionamento com a verdade revelada; e as técnicas como os atos e práticas de culto que possibilitam ao ser humano obter a redenção, seja pela oração, sacrifício, riqueza, cerimônia, serviço divino ou serviço social.

Quando falamos "religião", portanto, referimo-nos a um conjunto amplo de símbolos que abrangem a sociedade e a cultura com a tarefa de dar significado ao mundo e a vida, ditando aos acontecimentos cotidianos, um caráter dicotômico: sagrado e profano, puro e impuro, ético e não ético. Assim, as religiões, as religiosidades, as crenças diversas, as filosofias, enfim, todas as formas de significadoras da realidade, determinam a maneira como homens e mulheres se colocam no mundo, servindo de orientação para o relacionamento entre seus pares e com a natureza e para a constituição de identidades culturais (CECCHETTI, 2012).

Partindo desses pressupostos, e considerando o ser humano como um microuniverso em totalidade e complexidade entendemos que quando ele vai à escola, suas crenças e hábitos, sua forma de interpretação moral e material do mundo também o acompanha. Nesse sentido, a escola configura-se como um macrouniverso de encontro e desencontros em múltiplos aspectos, inclusive o religioso. E eis porque debatê-lo sob a égide da inclusão: não é uma defesa acerca do culto religioso na escola, nem da eleição de preceitos de uma determinada instituição ou denominação religiosa como norteadores do trabalho pedagógico, mas, ao contrário, coloca-se em debate a diversidade de formas com que o ser humano se relaciona ou não com sobrenatural, bem como as formas como essa relação com o divino interfere na 
relação entre os seres humanos.

\section{DO ENSINO DE RELIGIÃO A UM ENSINO RELIGIOSO}

A religião sempre foi um fator influente no Brasil. A chegada dos exploradores e colonizadores portugueses, entre o século XV e XVI, era acompanhada de representantes da doutrina oficial do Império, o Catolicismo. Se os próprios índios, habitantes e donos legítimos do território brasileiro, não foram levados em consideração e, sob a justificativa de serem povos desprovidos de alma, muitos tiveram suas vidas ceifadas, a sua religiosidade e as crenças tiveram o mesmo destino.

O ensino de religião que chegou com as embarcações, por anos foi o responsável pela formação do povo que vivia no território a leste de Tordesilhas. Através do catecismo, a educação dava seus primeiros passos, aumentando o império do catolicismo e domando índios e, posteriormente, dos negros escravizados. Junqueira (2011, p. 31) destaca que "o instrumento básico para essa área da educação era o catecismo, por meio do qual se realizava a instrução religiosa e também contribuía como cartilha de alfabetização".

À medida que os colonizadores foram avançando pelo território brasileiro, igrejas eram erguidas formando povoados e ditando as regras da vida em sociedade. Cecchetti (2012, p. 7) denominou esse ensino como civilizatório-colonizador,

[...] difundindo os preceitos tidos como únicos e universais. O currículo e a organização do cotidiano escolar visavam tão somente catequizar os sujeitos, enfocando uma verdade padronizadora que 
negava quaisquer outras formas de religiosidades/ tradições religiosas.

Ainda segundo Cechetti (2012), até a Proclamação da República, em 1889, a diversidade religiosa era ignorada, sendo combatida como uma ameaça à nação brasileira. Religiões diversas ao catolicismo - como o judaísmo, o luteranismo e outras configurações protestantes, as expressões religiões de matrizes indígenas e africanas - eram proibidas de serem manifestadas publicamente, sob a justificativa de garantir a ordem pública.

Já na República, em 1889, a Igreja se separa do Estado mediante o decreto 119-A, de 07 de janeiro de 1890, redigido por Ruy Barbosa, proibindo atos executivos, legislativos e judiciários sob a égide de alguma religião, bem como a diferenciação entre os habitantes entre a nação por motivos de crença, opiniões filosóficas ou religiosas. No entanto, no plano educacional, o ensino religioso ainda carregava a herança da colonização: a expressão do cristianismo prevalecia, sobretudo sob orientação católica, ignorando a diversidade religiosa existente com a presença dos índios, imigrantes e pessoas escravizadas trazidos da África e negociados em nosso país.

Em 1891, a promulgação da Constituição Federal da República Brasileira, estabelece, de fato, a separação entre a religião Católica Apostólica Romana e o Estado Brasileiro, inclusive no âmbito educacional, passando a vigorar o que consta no PCN, "será leigo o Ensino ministrado nos estabelecimentos oficiais de ensino" (BRASIL, 2004, p. 14). 
Mesmo separada, a Igreja continuava ditando regras na sociedade, reaproximando-se do Estado na Constituição de 1934. A Igreja Católica mantinha influência na educação e sempre se posicionava contra a Escola Nova, defendida por diversas personalidades da época, considerados comunistas e até hereges. A Igreja demonstrava sua influência política, fazendo prevalecer suas opiniões e preceitos.

O Ensino Religioso no Brasil percorreu caminhos diferentes: no início o ensino era evidentemente confessional e exclusivamente católico; mais tarde, devido os acontecimentos da história política e social, assumiu o caminho da interconfessionalidade; atualmente, vislumbram-se práticas pedagógicas que se embasam no conhecimento das religiões, dedicando-se as culturas e as tradições religiosas, substituindo o caráter de catequização, condenado por críticos que a consideravam tal prática manipuladora.

Junqueira (2011, p. 19) lembra que a década de 90 foi marcada pelas mudanças consideráveis do Ensino Religioso:

Vive-se um tempo de profundas mudanças de ordem social, política e econômica. Mudanças estas no campo da ciência e das criações de novas tecnologias, nacional e internacionalmente. Entramos na política da globalização. Surgiram as chamadas reformas de ensino, que provocaram mudanças no processo educacional de todos os países e, de modo especial, na América Latina, o principal alvo.

Vários fatores acarretaram essas mudanças no formato do Ensino Religioso no Brasil. Além da Constituição de 1988 que firmava a laicidade do estado brasileiro, a Igreja Católica, que 
durante anos foi a religião que detinha o maior número de seguidores no país, começava a perder espaço para outras religiões em seus diversos seguimentos. Mudanças eram necessárias, sobretudo para o reconhecimento da diversidade religiosa presente no país.

\section{RELIGIÃO, EDUCAÇÃO E O ESTADO LAICO: \\ O CONTEXTO POLÍTICO E CURRICULAR DO ENSINO RELIGIOSO}

Dentre as manifestações culturais do ser humano, a religião é a peça fundamental na expressão da fé. Fazer parte de um grupo, ser identificado como membro de algum sistema o localiza no mundo. A religião orienta o indivíduo ao relacionamento com seus semelhantes e também com a natureza, criando uma identidade cultural.

A Constituição Brasileira de 1988, em seu artigo art. 210, parágrafo primeiro, determina que a religião faça parte da formação, introduzindo o ensino religioso nas escolas, mas mesmo diante dessa obrigatoriedade não deixa claro quem ensina e o quê se deve ensinar. Fica a cargo do estudante e seus responsáveis, o desejo ou não de frequentar as aulas de Ensino Religioso. O caráter facultativo de um modo geral não é respeitado pelo fato da população desconhecer tal lei tornando a presença algo obrigatório. $\mathrm{O}$ motivo de se fazer valer a presença se dá pelo simples fato da escola não ter alternativas para ocupar o aluno que não demonstre interesse no conteúdo das aulas de Ensino Religioso.

Um Ensino Religioso Constitucional é criticado por cor108 
rentes que afirmam que, sendo o Brasil um Estado laico, ou seja, imparcial nos assuntos religiosos, ao introduzir religião na escola pública, estaria promovendo-a como um valor essencial para o convívio em sociedade. Outro fator discutido sobre o ensino religioso aponta que mesmo sendo laico, fica claro no Brasil a influência das religiões cristãs que promovem um afastamento das religiões consideradas minoritárias como as indígenas e as de matrizes africanas. Seria possível promover um diálogo harmonioso entre essas religiões no ambiente escolar? Seria o Brasil um Estado laico apenas na constituição?

Essa laicidade já fora questionada várias vezes quando os símbolos religiosos marcam presença em repartições públicas. Marques (2014, p. 2) reconhece que

[...] o tema vem sendo discutido, tanto nos tribunais quanto na doutrina, mas não há um consenso majoritário. Alguns doutrinadores acreditam que o tema é de pouca relevância, pois a simples presença de um símbolo não feriria a laicidade do Estado.

Ao regulamentar o ensino religioso, a Lei de Diretrizes e Bases da Educação de 1997 em seu art. 33, delegou aos estados o poder de definir a qualificação exigida para lecionar o ensino religioso, bem como seu conteúdo. Diante disso, encontramos uma diversidade de regulamentação de estado para estado, fazendo com que o Ensino Religioso do Espírito Santo seja diferente daquele que é ministrado no Rio de Janeiro ou em São Paulo, por exemplo. 
O Estado do Espírito Santo oferece o Ensino Religioso no Ensino Fundamental, nas escolas públicas, por exemplo, tendo como base a Resolução CEE/ES nº 1.900/2009 (CONSELHO ESTADUAL DE EDUCAÇÃO, 2009). Esta resolução fortaleceu a presença do Ensino Religioso nas escolas capixabas e foi útil para regulamentar o ensino e viabilizar cursos de formação de professores para atuar em sala de aula, o que não significa que o problema esteja sanado e as discussões cessadas. Conforme aponta Dias (2012, p. 27) numa pesquisa sobre o Ensino Religioso no município de Vitória:

\begin{abstract}
As instituições de ensino superior recomendada pelo CONERES não tiveram alunos suficientes para formar turma para o curso de especialização em Ensino Religioso, apenas uma instituição no Estado está com uma turma em andamento. Nesse contexto de grandes desafios, a Secretaria de Educação do Estado tem feito grandes avanços, por exemplo, a proposta do currículo básico de ensino religioso nas escolas.
\end{abstract}

A falta de profissionais habilitados para estar à frente de uma sala de aula e a falta de atividades para alunos que não optaram pela disciplina de Ensino Religioso representam apenas alguns dos problemas enfrentados pela legislação e a estrutura organizacional da educação no estado. O currículo básico já formatado pela Secretaria, também está na mira de críticos que questionam os valores discutidos e continuam afirmando a necessidade da religião para o ser humano em sala de aula, gerando um desconforto aos sem-religião e aos ateus. Dos problemas enfrentados, Dias 
(2012, p. 30) lembra que "um dos grandes desafios das escolas é efetivar uma prática de ensino voltado para o não preconceito religioso e superar o desrespeito à diversidade cultural e religiosa".

A Secretaria de Educação de Vitória/ES dá poderes ao diretor da escola de não ofertar a disciplina de Ensino Religioso, diante da falta de professores capacitados. Fica o Ensino Religioso, mesmo previsto em constituição, disponível apenas em localidades onde os obstáculos iniciais foram vencidos, mas novos obstáculos surgem quando os alunos estão em sala.

\section{QUESTÕES CONTROVERSAS LIGADAS À RELIGIOSIDADE NA ESCOLA}

Além dos problemas presentes em sala de aula, os conflitos entre religiões, o que deve ser e o que não deve ser abordado na disciplina de Ensino Religioso, nos deparamos com um conflito de teorias que discutem a origem do universo, geralmente, a cargo de professores da disciplina Ciências Naturais.

Em países da Europa, como França e Suécia, a religião não é discutida em sala de aula sob a justificativa de que um estado que se declara laico não deve discutir com os alunos a respeito de teorias que não sejam científicas. Portugal é um país de maioria católica, atualmente e nos seus primórdios, estando a explicação criacionista presente nas escolas. Diferentemente acontece nos Estados Unidos e Japão, onde a religião fica do lado de fora da escola.

Nos Estados Unidos, o ensino da evolução biológica sofre a resistência de organizações criacionistas, principalmente nas 
regiões com altas proporções de protestantes evangélicos. Essa situação gerou debates históricos, e também o desenvolvimento de um grande número de pesquisas sobre o ensino da evolução biológica (TIDON e VIEIRA, 2009).

No Brasil a situação se difere pelo fato das religiões possuírem influência no contexto escolar e político. $\mathrm{O}$ criacionismo e o evolucionismo andam juntos e dividem opiniões. Existem movimentos criacionistas que defendem seu ensino nas escolas. Pesquisadores do assunto apontam que aceitação e/ou rejeição das teorias que estão relacionadas a fatores como grau de instrução dos pais, renda familiar e/ou a orientação religiosa. Existem religiões abertas à discussão e outras que não dialogam.

Pode ser que os próprios alunos concordem que o criacionismo também deva ser abordado em sala de aula como uma teoria alternativa ao darwinismo, mas a influência da religião e o entendimento dos pais podem modificar o quadro quando não compreendem a diferença entre uma teoria científica e uma concepção religiosa. Como seria deixar de abordar a teoria da evolução na escola diante da diversidade de religiões e até mesmo a presença dos sem religião em sala de aula? Deveríamos priválos do conhecimento por causa de religiões que não aceitam as teorias científicas?

Nota-se que as religiões, mesmo fora do ensino religioso, exercem grande influência no contexto escolar. Um exemplo dessa influência ocorreu na campanha de vacinação contra o vírus HPV realizada nas escolas do Brasil, em março de 2014. O público alvo da campanha eram meninas entre 10 e 13 anos, que 
receberiam gratuitamente pelo Sistema Único de Saúde (SUS), a vacina contra o Papilomavírus humano (HPV), vírus transmitido por contato sexual que vem sendo considerado a principal causa do câncer do colo de útero.

No caso específico do Espírito Santo, a vacinação das adolescentes foi fortemente boicotada por grupos de pais, sob orientação religiosa, que queriam evitar que suas filhas tomassem a vacina. Afirmavam que a mesma podia incentivar a prática sexual precoce. O boicote foi divulgado pela mídia em todo o Estado. O presidente da Associação de Pastores Evangélicos da Grande Vitória se pronunciou sobre o assunto, dizendo acreditar que a vacina é uma boa solução para a doença, mas definia a fidelidade como a melhor forma de prevenção. (Referência, jornal A GAZETA impresso ou online).

Trata-se de um típico caso de influência da religião no processo decisório na vida do homem descrito por Marx:

O homem faz a religião, a religião não faz o homem. E a religião é de fato a autoconsciência e o autossentimento do homem, que ou ainda não conquistou a si mesmo ou já se perdeu novamente. Mas o homem não é um ser abstrato, acocorado fora do mundo. O homem é o mundo do homem, o Estado, a sociedade. Esse Estado e essa sociedade produzem a religião, uma consciência invertida do mundo, porque eles são um mundo invertido (MARX, 2010, p. 145).

Duarte e Neto (2011) consideram que os "representantes" conseguem oprimir os indivíduos a fim de levá-los a praticar aquilo que reflete os interesses das camadas dominantes daquela 
sociedade, seja ela qual for. Tal influência é notada não apenas no âmbito escolar, mas em diversos setores da sociedade como na política, economia e cultura.

\section{UM PLANO DE ENSINO EM DEBATE: O CONTEXTO DO ENSINO RELIGIOSO NO ESPÍRITO SANTO}

Considerando a multiplicidade de desafios concernentes ao Ensino Religioso enquanto disciplina, propomo-nos, a partir da análise de cinco planos de ensino anual (cinco primeiros anos do ensino fundamental), preparados e disponibilizados por um professor da rede estadual de ensino do Espírito Santo, atuante em uma escola do município de Serra, discutir as potencialidades que subjaz a disciplina para o desenvolvimento de práticas inclusivas no ambiente escolar, pautadas no reconhecimento da diversidade, em suas múltiplas configurações, e o respeito ao sujeito independente das características físicas, da maneira de pensar e da fé professada ou não.

Vale ressaltar que os planos de ensino disponibilizados pelo professor tem como fundamento o Currículo Básico da Escola Pública Estadual, que localiza a disciplina Ensino Religioso na área de Ciências Humanas, ao lado Geografia e História, estabelecendo como objetivo geral a promoção, compreensão, interpretação e (re)significação da religiosidade e do fenômeno religioso em suas variadas manifestação, linguagens e paisagens existentes nas culturas e sociedades. $\mathrm{O}$ documento norteador não aponta para um Ensino Religioso confessional, mas coloca-se diante da multiplicidade de manifestações culturais e religiosas 
promovendo a construção de uma participação respeitosa, incentivando a compreensão dos dissensos e conflitos e que leve a uma postura de abertura para o mundo a ponto de admitir a liberdade de escolha religiosa, o diálogo e a diversidade nos ambientes sociais de interação.

A abordagem proposta pelo professor nos cinco planos de ensino aponta para uma compreensão de um Ensino Religioso e de Religião que se paute na diversidade, na historicidade e no respeito, contribuindo para a formação moral do sujeito. É interessante pensar em um ensino que não se exima da discussão, tratando a religião como algo intocável e no qual não se cabe qualquer questionamento reflexivo.

Considerando, no entanto, que os planos de ensino são direcionados para os anos iniciais do ensino fundamental, no campo da didática/prática docente, é preciso que o professor examine com atenção a adaptação linguística e a utilização de exemplos concretos ao lado dos termos que remetem abstrações. Nesse sentido, as discussões mais abstratas, de nível estritamente conceitual, tornam-se mais proveitosas nos últimos anos dessa etapa inicial da educação. Sendo assim, partir do plano palpável, da experiência religiosa dos educandos seria um possível caminho a seguir e um rico terreno de reflexão a análise.

Observa-se que no campo específico do Ensino Religioso, um dos aspectos que o professor teve o cuidado de se distanciar foi de um formato de catequização. Apesar da predominância de questões religiosas típicas da cultura ocidental judaico-cristã e, dessa forma, de sua religiosidade, ainda há o contato com outras 
experiências e manifestações presentes na realidade de nosso país e do mundo.

Pode-se considerar positiva a proposição de discutir a religião e a religiosidade na perspectiva do respeito e da fraternidade, atentando para o nível da moralidade, da historicidade, da poesia e da cultura presente nessa expressão humana e desse contanto do homem com o mistério da transcendentalidade.

Há, no entanto, uma afirmação/conteúdo no plano de ensino destinado ao primeiro ano do ensino fundamental, no mínimo discutível: "a necessidade da religião". Ao mesmo tempo em que há um direcionamento para o respeito à diversidade de crença e de ritos religiosos, é preciso abrir ao respeito àqueles que não possuem religião, nem creem no transcendente. Um exemplo de afirmação que precisa ser refletida e combatida é de que todo ateu é mau ou imoral, ou mesmo, que todo ateu necessita de conversão para encontrar a felicidade e salvação de sua alma. Da mesma forma que se levanta a bandeira pelo direito de expressar sua religiosidade e ser respeitado por ela, deve-se garantir o direito dos indivíduos de não crerem e não serem discriminados por isso.

O plano de ensino do segundo ano, por sua vez, apresenta a discussão de religião territorializada. Tal proposta é extremamente válida por colocar os educandos a par de questões mais próximas de suas experiências e de seu cotidiano. Outra abordagem adotada nesse mesmo plano vai ao encontro de conteúdos atitudinais. Eis uma questão crucial: é preciso que o professor cuide para que não haja direcionamento monoreligioso na discussão moral, considerando que a concepção de bem e mal não é universal. 
Mais uma vez o ponto primordial é fugir da catequização, do predomínio de uma orientação religiosa e da visão de que ela é extremamente necessária para a construção moral do sujeito (não desconsiderando sua participação).

O plano de ensino do terceiro ano traz uma incursão interessante, mas perigosa: há o apontamento de cultos e ritos religiosos a serem abordados em sala de aula. Uma discussão que venha a abranger um leque de cultos religiosos precisa estar sustentada em fontes e bases fortes para evitar ou minimizar equívocos e discursos preconceituosos. Exemplo disso são os ritos de passagem de determinadas culturas religiosas que solicitam a mutilação ou a autoflagelação dos sujeitos. A circuncisão é um exemplo clássico dessa experiência "mutilatória" existente em diversas culturas.

Nesse mesmo plano há um direcionamento muito particular: propõe-se discutir os sete pecados capitais (gula, avareza, luxúria, ira, preguiça, soberba e inveja) e as sete virtudes (castidade, generosidade, temperança, diligência, paciência, caridade e humildade). Aqui encontramos, de forma evidente, um direcionamento para a tradição de boa parte dos cristãos. Mais uma vez cabe o alerta quanto à variabilidade cultural, moral e religiosa existente no mundo e o risco que se incorre de universalizar uma interpretação.

Ainda nesse plano encontra-se a apresentação e reflexão acerca dos símbolos e cultos religiosos. As observações acima são válidas, mas há de considerarmos o poder do diálogo como meio principal de apresentar a diversidade religiosa e de culto.

Os planos de ensino do quarto e quinto ano retomam dis- 
cussões anteriores e inserem alguns tópicos sobre intolerância religiosa. A questão da tolerância precisa ser reinterpretada de forma a elevá-la ao nível do respeito e da fraternidade. É claro que essa temática, no entanto, deve permear todo o processo de ensino-aprendizagem dessa disciplina, em específico, como se composse sua coluna vertebral.

\section{CONSIDERAÇÕES FINAIS}

O ambiente escolar é um espaço rico em diversidade e possibilidades de encontros. Ao mesmo tempo, desencontros, conflitos, intolerâncias e desrespeito à singularidade e a coletividade emergem diante da falta de reflexão e compreensão acerca dessa diversidade. A educação e as escolas se veem, nesse contexto, desafiadas a alcançar a sua condição de inclusiva, não se omitindo diante da multiplicidade de sujeitos que ela engloba, nem buscando homogeneizá-los. Ao contrário, é assumindo uma postura crítica e revolucionária, concordante com um paradigma social inclusivo, diante das injustiças sociais que excluem e marginalizam a muitos, diante do desrespeito sustentado no hábito e na cultura, diante dos descasos dos poderes públicos para com os cidadãos que clamam por sua dignidade, diante de práticas educacionais que desumanizam os sujeitos e os aproximam de máquinas abióticas, prontas para servir, sem questionar, ao mercado, diante de muitas outras contradições tão presentes na nossa sociedade é que esta qualidade - inclusiva - é merecidamente alcançada.

Inclusão, nesse sentido, deveria ser muito mais que um 
tema ou termo da "moda", mas uma experiência humana a ser exercitada desde os tempos mais tenros da infância. Por isso fala-se de uma educação inclusiva que, respaldada por investimentos políticos, econômicos e tecnológicos, ajam diretamente sobre a formação dos indivíduos numa busca da internalização de uma atitude inclusiva, ou seja, de forma que ela deixe de ser uma imposição governamental, um imperativo hipotético que se só se realiza pelas vias da recompensa e punição, mas transmute-se num imperativo categórico dos sujeitos em diversidade, como uma ação que tem valor por si mesmo, sem a busca de benesses advindas de outrem (LOPES; DAL'IGNA, 2012).

Sob essa perspectiva foi que inserimos o debate acerca da diversidade religiosa na escola, tomando como referência a polêmica disciplina de Ensino Religioso como potencializadora da reflexão em torno da construção de um ambiente e de uma atitude inclusiva, nos mais diversos aspectos, pautando-se numa cultura do respeito e da interação social, onde as vozes, opiniões, crenças e práticas sejam reconhecidas conforme a singularidade de cada sujeito. Nesse contexto, propomos cinco compreensões sintéticas e sugestões para uma prática pedagógica inclusiva, a saber: distanciamento de modelos catequizadores; compreensão da multiplicidade de entendimentos do fenômeno religioso; embasamento em práticas respeitosas e no reconhecimento da diversidade; não omissão das incongruências religiosas; e rejeição, reflexiva, da necessidade incontestável da religião para a vida humana.

Quanto à primeira compreensão sintética, entendemos que 
o Ensino Religioso, numa perspectiva inclusiva, precisa afastarse de todo modelo catequizador. As instituições religiosas já exercem a função de ensinar seus dogmas, preceitos e normas. A escola, de modo diferenciado, deve romper com uma prática pedagógica impositiva embasada em uma única fonte explicativa do fenômeno religioso, em prol de uma formação para a liberdade e para a cidadania. Não há sentido transmutar a escola em igreja/ terreiro/centro religioso. São, na medida em que lhes cabem, instituições importantes para o ser humano quando cada uma assume sua função específica e congregam para a formação completa do sujeito, nos aspectos conceituais, procedimentais e atitudinais.

$\mathrm{Na}$ segunda proposição evidenciamos que o Ensino Religioso precisa abrir-se à multiplicidade de compreensões do transcendente, evitando qualquer perspectiva sintetizadora, mas valorizando a diversidade de explicações e experiências. Nesse contexto, é válido destacar a historicidade do fenômeno religioso, suas interpretações e a sistematização do culto e das formas de comunicação com o transcendente pelas instituições religiosas e como elas foram e são modificadas pelo tempo e o contexto social, da mesma forma em que elas mesmas atravessam a sociedade exercendo sua influência e modificando-a.

A terceira questão sintética aponta que o Ensino Religioso, ao afirmar a diversidade de compreensão do fenômeno religioso, precisa fundamentar-se numa prática respeitosa e de reconhecimento da singularidade. Essa deveria ser espinha dorsal de toda prática pedagógica que busque a qualidade de inclusiva: 
respeito e reconhecimento. Os alunos e os professores precisam compartilhar de um ambiente em que seja possível expressar-se sem receio, sendo valorizados e respeitados em sua singularidade, bem como, onde os questionamentos não sejam ameaças nem agressões, mas que, ultrapassando o nível da tolerância, a relação entre os sujeitos seja baseada na interação, no diálogo e na construção de uma cultura de solidariedade e paz.

A quarta compreensão sintética reside na constatação de que entre as manifestações religiosas há diferenças e contrassensos. Nessa perspectiva, o Ensino Religioso não pode omitir as relações de incongruência, mas, por meio da criticidade, reflexão e respeito, permitir os encontros e desencontros reconhecendo a riqueza que permeia tal multiplicidade. Coloca-se a prova a proposta inclusiva: a prática pedagógica não pode se ater a uma homogeneização do fenômeno religioso, mas constituir-se perante a realidade, ora concordante, ora dissidente, promovendo e mediando o diálogo e o reconhecimento do valor de cada experiência com o transcendente.

$\mathrm{O}$ quinto entendimento sintético a que chegamos, aponta que o Ensino Religioso não pode se sustentar sobre a máxima da necessidade da religião de forma universal. $\mathrm{Na}$ verdade, essa máxima, ao invés de promover um ambiente de respeito às múltiplas constituições e experiências humanas, exclui os sujeitos que não professam nenhuma fé, nem congregam em nenhuma instituição religiosa. E essa é uma exclusão tendenciosa, pois, por exemplo, muitas vezes leva ao entendimento de que aquele que possui religião ou crê na existência e intervenção divina 
ou transcendente, não age de forma maléfica para a sociedade, enquanto que os que não se encaixam nesse grupo - como os ateus - são essencialmente ruins e produtores de maldade. A religião, nessa perspectiva, precisa ser vista como uma possibilidade de formação moral do ser humano, constituída dentro da história e da sociedade, não diminuindo, assim, aqueles que não creem.

Por fim, havemos de considerar que não podemos perder de vista que a religião faz parte das manifestações culturais do ser humano. Ela exerce influência sobre os sujeitos e seus grupos sociais: determina conceitos, estabelece condutas, cria expectativas, oferece explicações. A religião oferece elementos e proporciona experiências que, de alguma forma, o possibilita identificar-se com outros pela crença e esperança no que transcende a existência terrena. É uma importante forma de se compreender o homem e sua relação com o mundo e com o outro, mas não podemos tê-la como única, nem mesmo como a melhor.

Nossa intenção, feitas tais considerações, não é encerrar a reflexão com respostas universalmente válidas e indiscutíveis, mas apontar para caminhos interpretativos que contribuam para a configuração da disciplina de Ensino Religioso como um espaço-tempo propício para a construção de uma cultura inclusiva, extensiva a todas as instâncias da vida humana.

\section{REFERÊNCIAS}

ABBAGnANO, N. Dicionário de filosofia. Tradução Alfredo Bosi. São Paulo: Martins Fontes, 2007. 
BRASIL. Ministério da Educação. Secretaria de Educação Básica. Parâmetros Curriculares Nacionais de qualidade para a educação. Ministério da Educação. Secretaria de Educação Básica: Brasília (DF), 2004.

CANOTILHO, J. J. G. Direito Constitucional. 7. ed. Coimbra: Edições Almedina, 2008.

CECCHETTI, E.; Diversidade religiosa e currículo escolar: presenças, ausências e desafios. IX ANPEDSUL - Seminário de pesquisa em educação da região sul, 2012. Disponível em: <http://www. ucs.br/etc/conferencias/index.php/anpedsul/9anpedsul/paper/viewFile/2968/946>. Acesso em 12 jun. 2014.

CONSELHO ESTADUAL DE EDUCAÇÃO (Espírito Santo). Resolução $n^{\circ} 1.900$, de 23 de outubro de 2009. Diário Oficial [dos] Poderes do Estado do Espírito Santo, Vitória, 26 nov. 2009, p.13.

DIAS, S. M. Ensino religioso no município de Vitória/ES. Dissertação de mestrado - escola Superior de Teologia. Programa de Pós Graduação. Mestrado em Teologia. São Leopoldo, 2012.

DUARTE, A. L., NETO, L. B. Reflexões sobre a influência religiosa nas escolas do campo e seus intelectuais. Universidade Federal de São Carlos, 2011. Disponível em <http://www.cadernosdapedagogia. ufscar.br/index.php/cp/article/view/501/20>. Acesso em 12 jun. 2014.

JUNQUEIRA, S., WAGNER, R. O ensino religioso no Brasil - $2^{\mathrm{a}}$ ed. rev. e ampl. - Curitiba: Champagnat, 2011.

LOPES, M. C.; DAL'IGNA, M. C. Subjetividade docente, inclusão e gênero. Educ. Soc., Campinas, v. 33, n. 120, p. 851-867, jul./set. 2012. Disponível em: < http://www.scielo.br/pdf/es/v33n120/11.pdf > . Acesso em 12 jun. 2014. 
MANTOAN, M. T. E. Novos cenários de compreensão da aprendizagem. Educação em Foco, Juiz de Fora, v. 4, n. 2, p. 13-25, 1999.

A Hora da Virada. Inclusão: Revista da Educação Especial/ Secretária de Educação Especial, Brasília, Out. 2005, p.24-28.

MESQUITA, A. M. A. A Formação inicial de professores e a educação inclusiva: analisando as propostas de formação dos cursos de licenciatura da UFPA. 2007. 218 f. Dissertação (Mestrado em Educação) - Universidade Federal do Pará, Centro de Educação, Programa de Pós-Graduação em Educação, Belém, 2007.

MARQUES, P. V. S. A laicidade do Estado e a retirada de símbolos religiosos de repartições públicas. Jus Navigandi, Teresina, ano 18, $\mathrm{n}$. 3739, 26 set. 2013. Disponível em: <http://jus.com.br/artigos/25405>. Acesso em: 9 jun. 2014

MARX, K. Crítica da filosofia do direito de Hegel. 2. ed. revista. São Paulo (Ed. orig. 1843): Bontempo, 2010..

TIDON, R. e VIEIRA, E. O ensino da evolução biológica: um desafio para o século XXI. Com Ciência [online]. , n.107, pp. 0-0. ISSN 151976542009.

UNESCO. Declaração de Salamanca e linha de ação sobre necessidades educativas especiais. Brasília: CORDE, 1994. 


\section{EDUCAÇÃO INFANTIL E SEXUALIDADE: SUPERANDO PRECONCEITOS}

Haroldo Junior Evangelista Vidal Edmar Reis Thiengo

Se a sexualidade humana é complexa e desconhecida para muitos educadores, a sexualidade infantil traz o mesmo grau de complexidade, ampliada por uma série de preconceitos e tabus impostos pela sociedade da qual fazemos parte. Considerando a sexualidade inerente à saúde, à vida e, portanto ao desenvolvimento do indivíduo, o presente artigo discute a importância da temática nas séries iniciais do ensino fundamental como forma de promoção do conhecimento de si mesmo, de sua relação com o outro e, portanto, da sua sexualidade. Para tanto, o tema é debatido à luz de estudiosos e pesquisadores da área, em consonância com os Parâmetros Curriculares Nacionais, propondo ações e reflexões que apoiem os educadores no desenvolvimento de seu trabalho.

\section{PARA INÍCIO DE CONVERSA...}

De acordo com os Parâmetros Curriculares Nacionais a inclusão da sexualidade como temática nos currículos escolares se intensifica a partir da década de 1970, pois está traz à tona a importância da formação holística, de pensar o indivíduo como ser 
integral.

Na década de 1980, no entanto, a sociedade foi abalada pelo advento da Síndrome da imunodeficiência adquirida - AIDS batendo à porta, escancarando a presença de um vírus HIV (vírus da AIDS) então fatal e diretamente ligado às questões sexuais, associado principalmente aos jovens e à prática desenfreada do sexo, a falta de prevenção, à promiscuidade e com destaque à prática homossexual. Outra questão importante nesse período foi o crescimento do número de gravidez na adolescência (BRASIL, 2000, p. 11).

"Bota a mão no joelho, dá uma baixadinha, vai mexendo gostoso, balançando a bundinha". Na segunda metade da década de 1990, a criançada cantava e dançava ao som de músicas como a do grupo musical É o tchan. Passou a ser comum nesse período a exposição das crianças imitando adultos em todos os sentidos, como nas roupas, nos gestos, nos cabelos, na maquiagem e principalmente na dança, num processo prematuro de erotização infantil. A televisão sobrecarregava os programas com crianças na condição de adultos miniaturizados, essencialmente as meninas. Tais exageros despertou em autoridades e estudiosos a necessidade de ampliação dos debates sobre o tema e a possibilidade de contribuir para os avanços alcançados ao se tratar questões referentes à sexualidade. Se por um lado a criança estava passando por um processo de erotização exacerbada, por outro, a sociedade não poderia continuar a ignorar o fato de que as crianças são seres sexuados. Os debates chegaram à escola e desde então o assunto entrou em sua pauta, chegando hoje a 
ser parte integrante dos currículos, contemplado entre os temas transversais.

Pensando em sexualidade infantil e no trabalho a ser desenvolvido com crianças, a compreensão dos termos sexo e sexualidade são fundamentais num primeiro momento. Sexo é entendido como a forma biológica que é determinada pela genitália, ou seja, sexo nos dá a ideia de gênero e assim considerando, o indivíduo nasce homem ou mulher, ou com o sexo masculino ou feminino. A sexualidade por sua vez vai além da genitália, além das partes do corpo, sendo inerente ao ser sexuado, ou seja, "a sexualidade transcende a consideração meramente biológica, centrada na reprodução e nas capacidades instintivas" (NUNES e SILVA, 2006, p. 73).

Própria do ser humano, a sexualidade se manifesta nos indivíduos, nas suas diferentes formas e nuances, desde seu nascimento e perdura até a morte, ocupando dessa forma:

[...] grande importância no desenvolvimento e na vida psíquica das pessoas, pois independentemente da potencialidade reprodutiva, relaciona-se com a busca do prazer, necessidade fundamental dos seres humanos (BRASIL, 2000, p. 117).

Da mesma forma, a sexualidade está margeada e marcada pela história, religião, cultura e ciência, expressando e confundindo sentimentos e afetos, desejos e vontades, usos e abusos dos mais diversos e ocultos, que precisam ser considerados por educadores em geral: pais, professores, coordenadores, diretores, etc.

Ao adentrarem o ambiente escolar, as crianças trazem con- 
sigo uma série de valores e conceitos que são obtidos no espaço privado, recebidos de seus familiares. Tais noções são recebidas de forma implícita ou explícita, variando de acordo com o núcleo familiar de onde essa criança provém e se expressa por meio de sua fala e, principalmente, de seu comportamento.

Assim considerando, ao trabalhar a sexualidade na infância, é necessário compreender que a criança traz um conhecimento que chamamos conceito espontâneo, que não deve ser desprezado para que, a partir deste, se articule outros saberes, chegando ao conhecimento cientifico. A educação não deve ser limitada:

[...] nem pela experiência imediata da criança, nem pela separação entre o abstrato e a realidade que desqualificam o significado da aquisição do conhecimento que permite a compreensão e a transformação da realidade (OSORIO, 1989, p. $67)$.

A proposta do trabalho escolar não tem por objetivo substituir ou contrapor a educação recebida no seio da família, mas antes de tudo complementá-la:

Na sociedade ocidental, sobretudo a partir do século XVII, a criança era percebida como um ser assexuado, fato este que se interliga à ideia do sexo mau, sujo, pecaminoso, entre outras inúmeras conotações negativas conferidas à sexualidade. Neste sentido, importa desvelar como esta ideia se manifesta no cotidiano da instituição escolar, partindo do pressuposto de que está escola não se compõe de seres fragmentados, e que tanto os educadores quanto os educandos estão presentes na sua totalidade física, psíquica, social e também sexual, é preciso buscar um entendimen- 
to da criança que contemple organicamente estes aspectos (RIBEIRO, 1991, p. 29).

Se o ambiente escolar traz em seu contexto a compreensão das expressões e/ou manifestações sexuais para a criança, e este ambiente é um instrumento do indivíduo para a aquisição é uma de uma base científica, nesta perspectiva, desta relação também resultam elementos para impulsionar a transformação social, elaborando uma nova ética, a partir de uma educação dialética, fundamental para a formação do equilíbrio do adulto consciente.

$\mathrm{Na}$ busca de atender a tais necessidades, um tema que apresenta como fundamental é o desvelamento do modelo patriarcal, através do estudo das relações de gênero, uma vez que nossa sociedade caracteriza homem e mulher, separando papeis e funções.

A criança imita e traz para a escola as vivências do seu dia a dia, apresentando comportamentos, via de regra, determinados pelo modelo patriarcal. Historicamente, a prática escolar tem reforçado esse sistema que atribui ao gênero masculino força, coragem, esperteza, inteligência, valentia e privilégios sobre as mulheres (RIBEIRO, 1993, p. 94). As meninas, por sua vez, devem ser boazinhas, dependentes, frágeis, calmas, quietas, comportadas, bonitas e por que não dizer tolas, assim, segue-se impondo uma visão e uma práxis maniqueísta de sociedade, onde o homem é visto como o bem e a mulher, o mal (RAPPAPORT, 1995), e acrescentaríamos dizendo que ao homem é dado todo poder enquanto à mulher é reservado o papel de submissão.

Apesar dos padrões estabelecidos, há crianças que não 
se enquadram no modelo estereotipado de menino e menina. Ao fugirem desses estereótipos, considerados naturais, os comportamentos diferenciados são analisados sob a ótica da "criança-problema", tanto pelos adultos quanto por outras crianças. Sobre essa premissa heterossexista é a prática do preconceito, discriminação, negação, estigmatização ou ódio contra toda sexualidade não-heterossexual, sobre a questão, Louro afirma que a criança:

[...] supõe e institui uma consequência, ela afirma e repete uma norma, apostando numa lógica binária pela qual o corpo, identificado como macho ou fêmea determina o gênero (um de dois gêneros possíveis: masculino ou feminino) e leva a uma forma de desejo (especificamente, o desejo dirigido ao sexo/gênero oposto) (LOURO, 2004, p. 80).

Segundo Rappaport (1995) precisamos compreender os papeis de gênero enquanto aquisições culturais e que, por isso mesmo, podem e devem ser superados, dando significado a cooperação e a busca pela igualdade entre os gêneros. São manifestações que precisam ser trabalhadas em atividades e situações do cotidiano escolar.

A Proposta Curricular do Estado de Santa Catarina destaca que:

Os valores da sociedade patriarcal são injustos, na medida em que pressupõem a supremacia de um sexo sobre o outro, negando oportunidades criativas e realizadoras para ambos. A busca pela superação faz-se no sentido de tornar as relações afetivas e sexuais mais solidárias e mais felizes (SANTA CARARINA, 1998, p.16). 
Dessa forma, há necessidade de se questionar os modelos prontos e propor a busca por novas possibilidades que estejam em consonância com o indivíduo e suas necessidades.

\section{CAMINHOS POSSÍVEIS}

Ao se trabalhar com a criança é preciso superar a preocupação com listagens de conteúdos lineares, sequenciados e seriados. A relação da criança com seus movimentos inventários e ingênuos, bem como a sua percepção destituída de pré-conceito em relação ao seu corpo possuem características lúdicas no que se refere ao âmbito expressivo de sua corporeidade infantil, ali são próprias e naturais a alegria e a satisfação consigo mesma.

Neste ínterim, jogos cênicos, atividades artísticas, elaborações textuais que produzem representatividade diversas, podem trazes resultados importantes à formação de repertório das crianças, desconstruindo estereótipos eternizados na inconsciência coletiva. Essa forma não inibe a criança, e permite que ela avance no sentido de superação de suas curiosidades, o conhecimento de si mesma e, manifeste novos interesses pelo assunto. (RIBEIRO, 1996, p. 56).

Assim pensando, a Proposta Curricular do Estado de Santa Catarina dispõe:

Nesta perspectiva, o/a professor/a exercerá a função de mediador/a entre o conhecimento que a criança possui e o conhecimento elaborado que, a priori, se supõe ser de seu domínio. Além disso, é fundamental a superação de tabus, preconceitos e 
crendices que consideram a sexualidade e o prazer como fontes do mal e do pecado, e por isso vistocom desconfiança (SANTA CATARINA, 1998, p. 16).

Ribeiro (1996) comenta que toda e qualquer curiosidade sexual infantil deve ser respeitada e, a partir dela, se estabelece uma relação de confiança entre professor e aluno, no nível do diálogo, da palavra e da cientificidade que requer o conhecimento acerca da sexualidade.

O comportamento omisso e distanciado do educador, quando, tem evidenciado a neutralidade como um atributo à deseducação sexual. Essa desculpa talvez servisse em tempos passados. A criança de hoje, desde muito cedo, estabelece relações diretas com imagens de vivências amorosas, afetivas e sexuais. Exemplo disso são as imagens veiculadas pela televisão, cinema, cartazes, revistas, entre outros meios de comunicação moderna. (RIBEIRO, 1996, p. 57).

Se por um lado a escola não tenha por objetivo assumir o papel da família, por outro lado, tem assumido responsabilidades relativas à educação e da estruturação da criança, papel que anteriormente era de responsabilidade dos pais ou responsáveis. Para Outeiral (2006), o currículo das escolas deve contemplar além do trabalho cognitivo, físico e emocional, atividades que promovam a saúde e a prevenção de doenças sexualmente transmissíveis, portanto, a preservação o cuidado com seu corpo.

A necessidade de promoção de temas que promovam a interação em detrimento da repressão da dúvida e da curiosidade, 
propor atividades que estejam à disposição da liberdade de expressão e do autoconhecimento, em detrimento da imposição e dos modelos prontos, é fundamental para a construção do desenvolvimento integral do sujeito.

A ideia de que a criança "normal" era um ser assexuado, e que toda e qualquer manifestação "precoce" de curiosidade sexual enquadrava-se no âmbito da anomalia e era proveniente do modelo familiar burguês, que se produziu por toda a Europa a partir do século XIX, já fora superada. Seus expoentes máximos são a ciência positivista e a moral vitoriana e, apesar das contribuições freudianas, inaugurando a teoria da criança sexuada, ainda hoje há profissionais da educação que se pautam na ideia de que a criança necessita ser tratada com rigor e com repressão para que se construam nela os limites morais socialmente aceitos (RIBEIRO, 1996, p. 57).

Ainda hoje, a ideia da criança assexuada paira no interior de muitos lares.

\section{CONHECENDO-SE PARA CONHECER}

Explorando o próprio corpo e comparando-o com o corpo do colega, a criança se descobre sexuada e se reconhece num corpo de menino ou de menina. A partir de então, a criança começa a perceber e compreender as relações homem/mulher, que anteriormente não significava muita coisa para ela. Começa a preocupar-se com tais diferenciações e busca significar e significar-se nesse contexto.

A sociedade contemporânea, ao mesmo tempo 
em que nega uma educação sexual voltada para a vida, impõe a uma parcela das crianças, jornadas intensas de trabalho forçado - no campo e na cidade - como também exclui uma parcela significativa dos direitos mais fundamentais de se viver dignamente, abandonando crianças e jovens à revelia do cruel, da exploração e da morte. (PEREIRA, 1996, p. 35).

Educação sexual infantil passa, necessariamente, pelo amor, respeito e pelo direito fundamental que é a apropriação do saber e do conhecer-se. O educador Marti (apud TOVAR, 1995, p. 21) afirma que "não existe igualdade social sem igualdade de conhecimento". Portanto, negar o conhecimento à criança é negar-lhe, também, dignidade social. Dentre as manifestações de curiosidade infantil e descobertas corporais individuais e coletivas, podemos citar as mais frequentes: diferenças físicas entre o menino e a menina, o tocar-se e consequentemente o conhecer-se, a imitação e representação da sexualidade adulta, os desenhos, gestos e palavras considerados obscenos.

O autoerotismo infantil entendido como:

Auto-erotismo ou prazer solitário e a possibilidade que as pessoas tem de alcançarem o prazer sexual sozinhos e em todas as idades. Significa, também, a possibilidade de alcançar o orgasmo sem, necessariamente, envolver-se com outras pessoas (PINTO, 1997, p. 50).

Caracteriza-se, portanto, pela descoberta do prazer localizado no próprio corpo. As formas mais comuns desta manifestação apresentam-se pela manipulação, pelo friccionar dos genitais em 
brinquedos (gangorra, cavalinho, balanço, escorregadores, entre outros) e pelo contato direto com o corpo de outras pessoas ou objetos (cadeiras, sofás, corrimãos, etc...). É importante alertar as crianças sobre os perigos ao manuseio de objetos, pois estes podem machucá-las. Convém salientar que o prazer experimentado nessa situação, embora localizado e difuso, não se iguala ao autoerotismo adulto. $\mathrm{O}$ autoerotismo infantil é considerado pelas ciências que estudam o desenvolvimento humano como uma das tantas descobertas de prazer corporal, que acontece na vida dos indivíduos desde o nascimento, e é muito importante no processo do conhecimento de si mesmo.

Foucault (1980) esclarece que:

[...] segundo círculos cada vez mais estreitos, o projeto de uma ciência do sujeito começou a gravitar em torno da questão do sexo. A causalidade no sujeito, o inconsciente do sujeito, a verdade do sujeito no outro que sabe, o saber, nele, daquilo que ele próprio ignora, tudo isso foi possível desenrolar-se no discurso do sexo. Contudo, não devido a alguma propriedade natural, inerente ao próprio sexo, mas em função das táticas de poder imanentes a tal discurso (FOUCAULT, 1980, p. 68-69).

A busca pelo conhecimento do próprio corpo pela criança deveria ser processo natural, no entanto, por possuir uma visão erótica do corpo, os adultos preocupam-se com tal processo de descoberta, desqualificando todo o qualquer mecanismo vinculado a este processo, imaginando ocorrer com as mentes infantis o mesmo que ocorre com a mente dos adultos. Tocar-se e 
tocar o outro, principalmente na região genital, é considerado por adultos como anormal, como desvio de conduta ou ainda como a expressão do uso inadequado da sexualidade. Aos poucos as crianças aprendem que o prazer que sentem ao, por exemplo, enxugar a genitália, é inadequado, feio e anormal, mas como mesmo assim continuam sentindo tal prazer, aprendem a esconder ou então se sentem sujas e por consequência se autoflagelam, sendo a forma mais comum de autoflagelo, a culpa.

Os jogos ou brincadeiras ligadas à sexualidade entre crianças da mesma idade ou idades aproximadas devem ser entendidos como mais uma maneira para conhecer-se e conhecer o outro, que inclui tocar partes do corpo para estabelecer diferenças e, também, sentir prazer. Esse comportamento faz parte da curiosidade infantil, tal qual abrir gavetas, portas de armários, vasculhar o que é desconhecido, sob e sobre o que está encoberto.

A curiosidade é inerente à espécie humana, mas quando se refere à curiosidade sexual, devido aos valores históricos, moral e religioso, que de "certa forma molda a cultura humana", provoca desconforto no mundo adulto, chegando a ser interpretada, rotulada e discriminada como disfunção sexual. Por isso, na educação infantil e nas séries iniciais, sugerem-se atividades de jogos corporais e trabalhos de diversas formas sobre o esquema corporal humano.

\section{CABE AO EDUCADOR}

O educador, ao planejar suas atividades, deve analisar os materiais didáticos que de forma direta ou indireta utilizam o 
corpo como tema, verificar se omitem partes do mesmo, como por exemplo, a genitália. A omissão é considera inapropriada por apresentar o corpo de forma mutilada, não correspondendo ao real, uma vez que a genitália compõe o biológico humano e, portanto, precisa ser trabalhada como as demais partes do corpo e com a mesma naturalidade. Faz-se necessário partir do conhecimento que a criança traz consigo, mesmo que seja um vocabulário que nomeiem as genitálias por apelidos. Cabe ao professor trabalhar a variação do vocabulário da criança até chegarem à nomenclatura científica.

Vale ressaltar que a educação sexual e processual e que não se esgota em series e/ou idades. Contudo, "costuma-se acreditar em nível de senso comum" que a sexualidade inicia-se a partir da menarca (primeira menstruação feminina) para as meninas e da polução noturna para os meninos, por serem estes fatores determinantes biológicos da pré-condição da procriação e por ocorrerem frequentemente na puberdade ou pré-adolescência. (ROCHA, 1995, p. 10).

A concepção de educação sexual, defendida neste documento, considera que o conhecimento científico e a linguagem afetiva devam ser trabalhadas/consideradas a partir do ingresso da criança na escola, como uma das possibilidades de conquista da autonomia afetiva, da liberdade de escolha e de uma vida mais consciente.

Os Parâmetros Curriculares Nacionais localiza essa temática entre os temas transversais, temas estes "que tratam de processos que estão sendo intensamente vividos pela sociedade, 
pelas comunidades, pelas famílias, pelos alunos e educadores em seu cotidiano" (BRASIL, 1998). Tratam portanto de questões urgentes sobre a realidade e que perpassam todas as áreas do currículo escolar, assim é que a Ética, a Pluralidade Cultural, Meio Ambiente, a Saúde, e a Orientação Sexual, são temas importantes na atualidade educacional.

Num passado muito recente, crianças "brincavam de papai e mamãe", "médico e enfermeira", como forma de saciar suas curiosidades. $\mathrm{Na}$ atualidade, crianças persistem nestas brincadeiras, mas estão diretamente ligadas a um mundo muito mais erotizado e sexualizado. Por exemplo, os heróis dos desenhos infantis já não são mais assexuados como as de décadas passadas, da mesma forma, as bonecas são produzidas de forma erotizada e, além disso, vem acompanhadas de namorados por vezes grávidas, reproduzindo comportamentos que retratam novas posturas femininas, recentes atuações coletivas, todas estas atreladas às mudanças sociais e culturais, dentre outra, da pós-modernidade.

Bauman (1998) afirma que:

[...] no discurso dos nossos dias, a criança aparece como o objeto, em vez de sujeito, do desejo sexual. Se o lançamento da criança no molde do sujeito sexual justificava a proteção compreensiva e íntima dos pais, a criança como objeto sexual requer reticência, distância e reserva emocional dos pais. O primeiro fato serviu ao fortalecimento (alguns diriam: estreitamento) dos laços familiares [...] o segundo serve ao enfraquecimento dos laços, uma condição importante da "monadização" do futuro colecionador de sensações de consumidor de impressões (BAUMAN, 1998, p. 189). 
Um trabalho pedagógico que utiliza os brinquedos das crianças, seus personagens prediletos, que pratique com elas as brincadeiras que fazem parte do seu mundo particular, pode auxiliar o processo de busca de respostas para explicar aquilo que lhes parece confuso, bem como produzir conhecimentos sobre combate as violências, sem traumas, punições e repressões. Isto porque as crianças, por não terem se apropriado da forma dicotomizada do mundo privado e do mundo público, poderão manifestar suas expressões sexuais no espaço escolar, sem que isto seja um problema para elas (NUNES e SILVA, 2006).

\section{FINALIZANDO...}

Propor formas de representar o ideário infantil, representar o seu imaginário, imitar e/ou representar vivencias sexuais apreendidas do mundo adulto, devem ser compreendidas pelo educador como dimensões integradas do processo de aprendizagem e de desenvolvimento infantil. E quando ciente disto, ele deve trabalhar com as crianças, para estabelecer limites de sentidos entre o âmbito do privado e do público. Em nossa cultura as manifestações sexuais pertencem ao mundo privado e, por mais que sejam consideradas como uma simples demonstração de afeto, as carícias nem sempre serão bem aceitas se efetuadas em espaços coletivos. Mostrar os limites dos valores humanos à criança, como eles funcionam em nossa cultura imediatista, que a todo momento recebe mensagens vindas de todas as direções e das diversas fontes ao alcance da mesma, pode fazer com que 
a criança seja capaz de diferenciar atos que demonstram afeto daqueles que são considerados abusivos ou violentos.

\section{REFERÊNCIAS}

BAUMAN, Z. O mal-estar da pós-modernidade. Rio de Janeiro: Jorge Zahar Ed., 1998.

BRASIL. Ministério da Educação e do Desporto. Secretaria de Educação Fundamental. Parâmetros Curriculares Nacionais: pluralidade cultural, orientação sexual. Brasília: MEC/SEF, 1997.

FOUCAULT, M. História da sexualidade 1: A vontade de saber. 3. ed. Rio de Janeiro: Graal, 1980.

OLIVEIRA, Z. R. Educação Infantil: fundamentos e métodos. São Paulo: Cortez, 2002.

LOURO, G. L. Um corpo estranho. Ensaios sobre sexualidade e teoria queer. Belo Horizonte: Autêntica, 2004.

NUNES, A C. et al. Educação Sexual da Criança. Campinas-SP: Ed. Autores Associados, 2000.

NUNES, C.; SILVA, E. As manifestações de sexualidade da criança. São Paulo: Séc. XXI, 1997.

OUTEIRAL, J. In CEZIMBRA, M. Os novos desafios da psicanálise. Jornal O Globo, Rio de Janeiro, caderno Prosa e Verso, p. 1-2, 29 abr. 2006.

OSORIO, L.C. Adolescentes hoje. Ed. Artes Médicas. Porto Alegre, 1989.

. Proposta Curricular de Santa Catarina: Estudos Temáti- 
cos. Florianópolis: IOESC, 2005.

PEREIRA, Y. C. C. Concepção da relação aprendizagem e desenvolvimento subjacente a pratica dos professores em ensino de ciências nas series iniciais do I Grau ( $1^{\text {a }}$ a $4^{\text {a }}$ series). Dissertação (Mestrado em Educação). Florianópolis: UFSC, 1996.

PCN, Parâmetros Curriculares Nacionais - Educação Física, Brasília: MEC/SEF, 2013.

RAPPAPORT, C. Encarando a adolescência. São Paulo: Ática, 1995.

RIBEIRO, M. (org.) Educação sexual: Novas Idéias Novas Conquistas. Rio de Janeiro: Rosa dos Tempos 1993.

RIBEIRO, M. (org.) O prazer e o pensar. V.2. São Paulo: Gente, 1999. PINTO, H. D. S. A individualidade impedida: adolescência e sexualidade no espaço escolar. In: AQUINO, Julio Groppa (Org.). Sexualidade na escola: alternativas teóricas e práticas. São Paulo: Summus, 1997.

ROCHA, J. S. Educação sexual na infância: uma área emergente. (Monografia especialização em Ação Integrada dos Especialistas em Assuntos Educacionais). Florianópolis: FAEDA/DESC, 1994.

TOVAR, Carlos M. ¿Democracia en Cuba? Havana: Editorial José Marti, 1995. 


\section{JOSÉ-MARIA-JOSÉ: DISCUSSÕES ALÉM DO SEXYO BIOLÓGICO}

Antônio Lopes de Souza Neto

Janivaldo Pacheco Cordeiro

Robson Wilson Carneiro Onofre

Edmar Reis Thiengo

São todos iguais

E tão desiguais

Uns mais iguais que os outros

O cenário é a escola. No palco principal atrizes que poucas vezes se impõem e na maioria se escondem, amofinam, desaparecem. Procuram "não dar pinta", mas é possível? Seria um teatro para cegos? Ou fantasmas para os vivos? Pessoas, e porque não dizer, mulheres (no seu íntimo, ou fora dele) que se procuram e que muitas vezes não se encontram, e quando este encontro acontece, são menosprezadas, destruídas, estigmatizadas.

"É uma mulher ou é um homem?", diria uma senhora desavisada, intrometida ou curiosa(?), no primeiro dia de aula, ou pelo menos, no primeiro dia que uma figura como esta apareceria. "É um veado!", teria dito o senhor conservador. Nesta hora, risos e chacotas despontariam por todos os lados. Em breve, toda a escola estaria atravessando olhares, evitando encontros, desviando caminhos, apontando com dedos... 
Neste meio é certo que há também aqueles que respeitam as pessoas da maneira que elas são: se mulher, se homem, se veado, se travesti, se sapatão, se preto, se gente! Não importam, não rotulam. Não nos interessam também se aceitam, ou se "engolem", ou se é apenas educação e boa convivência, mas que respeitem!

Há tantos quadros na parede

Há tantas formas de se ver o mesmo quadro

Há tanta gente pelas ruas

Há tantas ruas e nenhuma é igual a outra

Ninguém é igual a ninguém

E então, não nos afeta, se atriz ou se ator, se julgamos como um faz de conta, se fingimos que aceitamos que é João mas deveria ser Maria, ou se é Samantha mas deveria ser Jheferson! “A certidão diz que é Jheferson, e não Samantha! Não vou rasurar meu diário! Se ele assistir a minha aula será chamado pelo seu nome de registro!" Por que tanta intolerância? A quem interessa "dar nome aos bois?"

Interessa a Samantha: "Nasci mulher num corpo de homem. Sou mulher! Sinto-me mulher! Tudo o que me envolve é feminino e então por que continuam a me chamar de Jheferson? Qual o problema de me vestir como mulher?” A história é fictícia, mas o conflito é real.

Eu não queria ter de entrar nesta ordem arriscada do discurso; não queria ter de me haver com o que tem de categórico e decisivo; gostaria que fosse 
ao meu redor como uma transparência calma, profunda, indefinidamente aberta, em que os outros respondessem à minha expectativa, e de onde as verdades se elevassem uma a uma; eu não teria senão de me deixar levar, nela e por ela, como um desenho feliz (FOUCAULT, 2006, p. 7).

Não desejaríamos que esse assunto fosse motivo de questionamentos e de discriminação. Afinal, como disse o poeta "Cada um sabe a dor e a delícia de ser o que é!”, cada ser sabe do seu íntimo e se comporta da maneira que se sente melhor e todos devem ser respeitados pela sua própria natureza de ser. A essa hora, o senhor conservador e a senhora curiosa estariam pensando naquela famosa frase "Deus fez o homem e a mulher, isso não pode estar certo!"

Agora o cenário é a sala de aula, geralmente a Educação de Jovens e Adultos (EJA). Sim: é neste segmento que se encontram todos aqueles que "a vida" fez o favor de excluir, ou que "a vida" aprontou para ser diferente. "Nós trabalhamos com a escória da sociedade" - disse certa vez uma pedagoga em um bate papo particular: "são os negros, os ex-presidiários, o menor assistido, o pobre, o branco esquisito, e, em especial, quando existem na escola: as travestis, os/as transexuais e transgêneros", foco principal deste estudo.

Me espanta que tanta gente sinta

(Se é que sente) A mesma indiferença

As discussões as quais nos propomos relatar foram desen- 
volvidas no curso de mestrado do Programa de Pós-graduação em Educação em Ciências e Matemática (EDUCIMAT) do Instituto Federal do Espírito Santo (Ifes), ofertado no Campus Vitória. Descreveremos uma dinâmica pedagógica intitulada "Roda de Conversa" realizada na disciplina "Diversidade e Inclusão Social em Educação em Ciências e Matemática”. Apontamos as observações e reflexões de professores e convidados quanto à temática da diversidade sexual como forma de contribuir para formação dos profissionais, suas ações e opiniões no contexto escolar e social a partir da dinâmica desenvolvida nesta disciplina.

A turma foi organizada em grupos que tiveram a liberdade de escolher as temáticas a serem abordadas. Optamos como tema a diversidade sexual no espaço escolar por ser um assunto de discussão extremamente importante para a conscientização e respeito à diversidade. Outra motivação, para a este trabalho foi a observação de que travestis e transexuais praticamente inexistem nos espaços escolares.

A dinâmica desenvolvida para tratar da temática da diversidade sexual na educação com os participantes da pesquisa tomou como ponto de partida o questionamento "Diversidade Sexual na Escola: onde estão travestis e transexuais?’. A disciplina contou com um espaço virtual no Facebook para fomentar e enriquecer os debates presencias. Foi neste espaço que, antes da aula presencial sugerimos a seguinte problematização:

Diversidade Sexual na Escola - Onde estão travestis e transexuais? No segmento LGBT, travestis e transexuais são as mais excluídas e que sofrem maior preconceito. A exclusão começa no espaço escolar que 
não respeita sua identidade de gênero. O nome social (nome que as pessoas trans adotam de acordo com sua identidade de gênero) e o uso do banheiro são questões importantes para a inclusão de travestis e transexuais. Qual sua posição a respeito? Você já estudou com alguma travesti ou transexual? Já teve alunos trans? (FACEBOOK, 24 de março de 2014).

Também sugerimos o vídeo "Amanda e Monick" (BRASIL, 18 min., 2008), documentário dirigido por André da Costa Pinto que retrata a história de duas travestis do Cariri Paraibano. Amanda é professora da rede pública e Monick, sua aluna. Amanda é respeitada pelos alunos e pela sociedade por sua condição e auto-afirmação de sujeito trans vinculado a importância do apoio familiar que se revela fortemente nas declarações do seu pai. Monick prostitui-se e mantém um relacionamento com uma mulher lésbica com expressão masculinizada (grávida, fruto do relacionamento com Monick). Em certo momento temos sensação de papeis trocados: um homem "grávido" de uma mulher (?!). A riqueza dos personagens e suas histórias constituem um bom material paradidático para o debate da diversidade sexual.

Para o encontro presencial contamos com a participação de convidados, militantes da causa LGBT de destaque no Espírito Santo e no cenário nacional, cuja identidade preservaremos. A roda de conversa proporcionou manifestações livres sob a mediação do grupo proponente. O perfil diversificado dos convidados possibilitou a abordagem de aspectos distintos relacionados à diversidade sexual.

há pouca água e muita sede 
(IN)DIFERENÇAS EM QUESTÃO: conversando sobre diversidades

uma represa, um apartheid

(a vida seca, os olhos úmidos)

entre duas pessoas

As convidadas de Adriana e Luiza ressaltaram as dificuldades que transgêneros enfrentam no cotidiano, reafirmando que travestis e transexuais, mesmo dentro do segmento LGBT, são as pessoas que sofrem maior discriminação. As manifestações dos mestrandos-educadores, tanto na aula presencial quanto no grupo virtual, evidenciaram o desconhecimento frente a travestilidade e a transexualidade. Constatou-se que nenhum deles tem ou teve contato próximo a travestis e transexuais. Apenas o professor da disciplina relatou ter tido uma aluna travesti. Esta é uma realidade presente em todo universo educacional. $\mathrm{O}$ depoimento do mestrando Marcos, traduz bem este fato:

Bem, eu nunca estudei ou tive alunos dentro deste aspecto, todavia sei que é direito a mudança do nome na pauta quando requisitado e concordo com tais condições, visto que esta é uma relação que se caracteriza por formação de identidade e como tal deve ser respeitada e compreendida. Acredito que haja espaços distintos dentro da questão levantada pelo nosso amigo - onde estão travestis e transexuais? - temos exemplos atuais de professores e outros profissionais que demonstram o quão preconceituosas é a questão e que ainda estamos caminhando para cumprimento dos direitos básicos nesses casos, porém, respondendo a questão - não sei onde estão, mas até então não os vi na escola (FACEBOOK, 24 DE MARÇO DE 2014).

A professora Adriana, 32 anos, mulher trans, estudante dos cursos de Especialização em Políticas Públicas em Gênero e Raça e de Aperfeiçoamento "Gênero e Diversidade na Escola", ambos ofertados pela Universidade Federal do Espírito Santo, desabafa 
sobre as dificuldades dos outros em percebê-la como mulher e relata sobre a necessidade que as pessoas tem em identificar os outros pela genitália, não respeitando a identidade de gênero de cada um. Adriana é uma exceção, enquanto Luiza é a regra: travesti, 26 anos, aluna de Ensino Médio na Educação de Jovens e Adultos no município de Serra-ES, onde também é atuante nos movimentos sociais com especial destaque no movimento LGBT, comenta sobre as inúmeras vezes que teve que evadir-se da escola por não a aceitarem como menina, sendo constantemente alvo de piadas e atitudes discriminatórias.

Correia Junior e Pedrini (2012, p. 248) dialogando com Judith Buttler e Marcos Eduardo Benedetti nos trazem reflexões sobre o ser e estar transgênero apontando as relações do corpo e o acesso ao meio social. Para os autores, pensar a sexualidade enquanto algo definido biológica e geneticamente definidos restringe a compreensão da transexualidade, afinal, neste processo ocorre uma desnaturalização do corpo que é moldado e readequado de modo a inseri-lo no mundo de acordo com a identidade de gênero, não determinada pela genitália.

O mestrando Marcos aponta um dos principais problemas que interfere na permanência e conclusão dos estudos de travestis e transexuais: desrespeito a sua identidade de gênero que também se materializa com a insistência em lhes tratarem pelo nome de registro e não pelo nome social e acrescentamos ainda, a ausência de banheiros que possam utilizar, pois a utilização de qualquer um deles poderia causar constrangimentos desnecessários.

Pedro, mestrando e professor na rede municipal de Cariaci- 
ca/ES, relata uma experiência com um aluno:

Ainda não tive colegas nem alunos travestis ou transexuais, porém já tive um aluno (sexo masculino) que me solicitou para ser chamado por outro nome, completamente diverso ao seu, por não se identificar com ele. Não tive a oportunidade conversar com ele sobre a solicitação, somente acatei a proposta, e como fez prof. xxxxx, fiz a observação na pauta para recordar. Mesmo que sejam situações diferentes, penso que a questão do nome civil e nome social correspondem à necessidade de reconhecimento do indivíduo enquanto cidadão desejoso de respeito e singularidade. A congruência entre o nome civil e o nome social é algo que pode estar presente na sociedade em diversas instâncias, não somente no contexto dos travestis e transexuais, mas sem dúvida são estes que tem levantado a luta pela dignidade a qual tem direito como seres humanos, haja vista que já vivem e sofrem o preconceito devido à incongruência social-biológica entre o "ser homem/ser mulher" $e$ "ser macho/ser fêmea" (FACEBOOK, 30 de Março de 2014).

A atitude de Pedro com o aluno traz à discussão um direito já garantido à estudantes transgêneros que é de usar o seu nome social. O Parecer $n^{\circ}$ 141/2009 do Ministério da Educação (BRASIL, 2009), a Resolução 2.735/2011 do Conselho Estadual de Educação do Espírito Santo (ESPÍRITO SANTO, 2011) A Resolução No 12/2015 do Conselho Nacional de Combate à Discriminação a Lésbicas, Gays, Bissexuais, Travestis e Transexuais (BRASIL, 2015) são alguns dos instrumentos garantidores, mas que ainda são poucos conhecidos tanto por estudantes quanto por professores. Educadores e educadoras demonstram não saber lidar com a questão além disso muitos deles carregados de preceitos religiosos perseguem ou ignoram completamente a suas existências.

A incongruência apontada por Pedro acarreta em casos de discriminação e preconceito pelos outros ou até mesmo da própria 
pessoa que por não se aceitar pela sua condição, acreditando não se enquadrar nos moldes comuns da sociedade. Esse processo de descoberta, de privação e de auto-afirmação é muitas vezes doloroso, numa sociedade que maltrata, discrimina e exclui.

\author{
me espanta que tanta gente minta \\ (descaradamente) a mesma mentira \\ todos iguais \\ todos iguais
}

Desde muito cedo somos guiados culturalmente a nos afastar daqueles que a sociedade, em geral, discrimina como aquilo que foge à dita normalidade, como se "ser normal" fosse o modelo a ser seguido, na qual o sujeito diferente se torna marginalizado, inferiorizado e invisibilizado, procurando os caminhos do isolamento. A postagem do mestrando Lucas reflete essa ideia:

Quem gostaria de estar num lugar onde constantemente é alvo de piadinhas e discriminação? Onde as pessoas não se aproximam para não serem também julgadas como iguais. Infelizmente a sociedade discrimina ao que foge dos padrões que ela julga aceitável. Ser travesti ultrapassa esse padrão e no entanto, são marginalizadas (FACEBOOK, 24 de Março de 2014, adaptado).

Ainda que não bastasse a "aceitação dos outros" muitos homossexuais vivem em conflitos de autoafirmação. Acreditamos que esse conflito pessoal de negação, também se concretiza por meio de preceitos religiosos, pois desde a infância, ouvimos que "os afeminados não ganharão o Reino dos Céus", ou que é 
“abominável aos olhos de Deus o homem deitar-se com outro como amante". E então, por esta análise, percebemos que os sujeitos trans (e suas variações) não estão presentes em muitos dos "cantos" que a Sociedade "permite", como escolas, igrejas, clubes entre outros, devido a ignorância própria ou alheia e essa, fixa "a eficácia suposta ou imposta das palavras, seu efeito sobre aqueles aos quais se dirigem, os limites de seu valor de coerção" (FOUCAULT 2006, p. 39).

Esse debate religoso foi colocado em pauta para discussão por outra convidada: a policial Marcela. Ela relatou que foi impedida de continuar a prestar os serviços na igreja que frequentava a partir do momento em que seu "pecado tornou-se público". Marcela se casou com sua companheira no ano de 2012 quando a Corregedoria do Tribunal de Justiça regulamentou a união civil de pessoas do mesmo sexo determinando que todos os cartórios do estado dessem o mesmo tratamento que o dispensado aos casamentos heterossexuais. A partir de seu depoimento, chegamos ao espaço escolar com relatos de violações da laicidade do estado.

Assim, o processo de não aceitação dos homossexuais, lésbicas, trans e congêneres se dá no campo da higienização do espaço urbano, à medida que se faz legitimado por discursos que carregam a neutralidade e cientificidade do conhecimento médico. Há muito o campo das ciências médicas tem se dedicado a encontrar respostas que possam apontar razões e lugares de pertencimento às sexualidades excluídas socialmente

Atualmente, tem-se produzido uma enormidade de discursos que possam justificar a existência do diferenciado, como forma 
de validar a subversão à norma. $\mathrm{O}$ que não se problematiza ou questiona e que ao passo que problematizamos o fato desses sujeitos não atenderem ao normatizado, mais precisamente à heteronorma, estamos conferindo à norma status de naturalidade. É preciso avançar no campo de discussões sobre o processo de naturalização da heterossexualidade, e assim promover um debate amplo sobre as sexualidades.

Bento (2008) disserta sobre as diversas instâncias de legitimação dos discursos legitimadores da heterossexualidade compulsória. Há o discurso religioso, o discurso pedagógico, o discurso médico, entre tantos outros discursos que são proferidos com o propósito de manutenção do sistema de sexualidade e gênero baseados no império biológico.

Embora saibamos que o discurso religioso sobre as condutas de gênero e as práticas sexuais continuam atuando nas subjetividades e produzindo julgamento, no espaço escolar, no entanto, é mais fácil utilizar os discursos médicos para legitimar a violência. Censura do tipo: "Não faça isso! É pecado!”, foi substituída por "isso não é normal! Comporte-se como um/a menino/a". O pecaminoso foi ressignificado no anormal (FOUCAULT apud BENTO, 2008).

Tais comportamentos categorizados como "de menino" ou "de menina" fizeram com que o menino sensível, afeminado fosse chamado de mulherzinha, florzinha, mariquinha, bichinha, Clodovil... enquanto a menina brutalizada, masculinizada era tratada como Maria machadão, sapatão, caminhoneira..., e assim, como não eram percebidos como normais, eram excluídos. 
Certeau (1994) aponta que cada individualidade é o lugar onde atua uma pluralidade incoerente (e muitas vezes contraditória) de suas determinações relacionais. Ser menino e comportar-se como menina, e vice versa, ainda nos dias de hoje causa 'desconforto' para muitos.

Esta sociedade machista e excludente que ao mesmo tempo tenta negar a existência desses sujeitos, enxergando-os como abjeções sociais e como seres inferiores - de condutas desviantes de "safadeza" e "viadagem"- luta não só através de seus discursos de 'moralidade' e de seus olhares de dúvidas, mas também através de suas práticas discriminatórias, para que esses sujeitos se tornem cada vez mais invisibilizados e segregados.

E, nesse sentido, nos aponta Foucault (apud VEIGA-NETO, 2011) à respeito da identificação das lutas sociais, seja contra a dominação (religiosa, de gênero, racial, etc.), seja contra a exploração do trabalho e, ainda, as lutas conta as amarras do indivíduo a si próprio e aos outros. Na formação do sujeito moderno e, mais além no sujeito desde sempre aí.

E nessa luta constante e por vezes involuntária, contra si mesmo e contra os outros, em combate com os seus conflitos, rejeições e aceitações é que o sujeito se forma, ou busca se formar e conformar. E assim procura se identificar como elemento participante dessa sociedade e nessa tentativa de (com)formação de sujeito reconhecido como pessoa, que se percebe o não pertencimento e a falsa ideia da auto-exclusão que a sociedade tenta demonstrar. São inúmeros os diálogos que permeiam essa meia-verdade: "Eles se isolam!" "Formam o seu grupo!”, "Quem 
anda com veado, veado é!"

\author{
Tudo fica claro \\ Ninguém fica indiferente \\ Ninguém $=$ ninguém \\ Me assusta que justamente agora \\ Todo mundo (tanta gente) tenha ido embora
}

É possível afirmar que a dinâmica empreendida na disciplina "Diversidade e Inclusão Social em Educação em Ciências e Matemática" trouxe-nos mais inquietações e revelações do que respostas. Pudemos constatar o quanto o assunto da diversidade sexual é pouco tratado no espaço escolar, sobretudo na formação inicial e continuada dos profissionais da educação.

E compreendemos, assim como Prado (2012 p. 24), que o que se tem se produzido na escola é um processo de homogenização das diferenças sexuais, à medida em que se propõe e se reitera o ocultamento das dimensões de regulação do sistema sexo-gênero que escapa até a própria crítica, já consolidada, das desigualdades.

Entendemos que "nem é de obscuridade que se deveria ainda falar, mas de uma luz um pouco confusa, falsamente evidente e que oculta mais do que manifesta" (FOUCAULT, 1999, p. 416), a qual aprisiona o ser transexual em seu mundo, em seu lugar de "abjeção social" e que a sociedade trata como inumano. Lembramos que são constantes as lutas para não se discutir esta questão na escola.

$\mathrm{O}$ rico debate com personagens, que vivenciam a luta cotidiana por respeito e por dignidade ainda que tenham uma 
orientação sexual diferente da maioria ou uma identidade de gênero diferente da esperada para o seu sexo biológico, levamnos a concordar com Rodrigues, Ramos e Silva (2012) quando afirmam que a escola é um dos dispositivos institucionais que se encarrega de produzir corpos sexualizados e generificados por meio de relações desiguais nos usos do poder.

Ainda é marcante a presença da homofobia no espaço escolar e o despreparo dos profissionais da educação para tal questão. Ainda que a temática esteja presente nos Parâmetros Curriculares Nacionais (BRASIL, 1998) como tema transversal, verifica-se um distanciamento com a prática cotidiana. Percebe-se que a frase de Simone de Beauvoir, "ninguém nasce mulher, torna-se mulher", é ainda pouco compreendida em nossa sociedade. Tal percepção remete a nós, a inquietante pergunta: até que ponto a biologização do ensino de ciências contribui para esta realidade em que papéis sociais são definidas pelas suas genitálias? Enquanto não encontramos a resposta a essa pergunta e colocarmos a prática à frente da teoria, viveremos repetindo e defendendo somente em músicas, direitos que deveriam ser reais.

São todos iguais

E tão desiguais

Uns mais iguais...

\section{REFERÊNCIAS}

BENTO, B. O que é transexualidade. $2^{\mathrm{a}}$ Edição. São Paulo- SP. Coleção Primeiros Passos, 2008. 222. 
BRASIL, Ministério da Educação. Parecer Técnico no 141/2009. Disponível em: http://siteantigo.mpes.mp.br/anexos/centros_apoio/arquivos/19_2145135254482014_Parecer\%20141\%202009\%20nome\%20 social\%20nos\%20registros\%20escolares\%20-\%20MEC\%20SECAD. pdf

, Conselho Nacional de Combate a Discriminação a Lésbicas, Gays, Bissexuais, Travestis e Transexuais. Resolução No $12 / 2015$. Disponível em: http://www.sdh.gov.br/sobre/participacao-social/cncd-lgbt/resolucoes/resolucao-012

CERTEAU, M. A invenção do cotidiano: artes de fazer. $11^{\mathrm{a}}$ edição. Petrópolis, RJ: Vozes, 1994.

CORREIA JUNIOR, J. A.; PEDRINI, M. D. Corpos em Trans-Formação: identidade e gênero em diálogo com travestis, transexuais, drag queens e transformistas. In: RODRIGUES, R.; BARRETO, M. A. S. C. (Orgs.) Currículos, gênero e sexualidades. Vitória - ES, Edufes, 2012.

ESPÍRITO SANTO, Conselho Estadual de Educação. Resolução No 2735/2011. Disponível em: http://www.cee.es.gov.br/download/ res2735.pdf

FOUCAULT, M. As palavras e as coisas. $8^{\text {a }}$ Ed. São Paulo: Martins Fontes, 1999.

FOUCAULT, M. A ordem do discurso. $13^{\text {a }}$ Ed. São Paulo, SP: Edições Loyola, 2006.

PRADO, M. A. M, et al. Escola e política do armário na produção das hierarquias sexuais no Brasil. In: RODRIGUES, R.; BARRETO, M. A. S. C. (Orgs.) Currículos, gênero e sexualidades. Vitória - ES, Edufes, 2012.

PINTO, A. C. Amanda e Monick. Documentário-DVD. Produção e direção de André da Costa Pinto. Brasil, 2007. 19 min, colorido, som. 
Disponível em: www.telefilme.net/sinopse-do-filme-13440_AMANDA-E-MONICK.html acessado em 24 de março de 2014.

RODRIGUES, A.; RAMOS, H. S. G.; SILVA, R. B. R. Gênero e sexualidade nas escolas: leituras que nos aproximam do campo dos direitos humanos, de alunos e professores. In: RODRIGUES, A.; BARRETO, M. A. S. C. (org). Currículos, Gêneros e Sexualidades. Vitória: EDUFES, 2012.

VEIGA-NETO, A. Foucault \& a Educação. $3^{\mathrm{a}}$ ed. Belo Horizonte: Autêntica Editora, 2011. 


\section{SOBRE OS AUTORES}

\section{ORGANIZADOR}

Edmar Reis Thiengo - Doutor em Educação, na linha de pesquisa Educação e Linguagem Matemática, pela Ufes, é professor titular do Instituto Federal de Educação, Ciência e Tecnologia do Espírito Santo (Ifes), vinculado ao Programa Educimat - Mestrado Profissional em Educação em Ciências e Matemática. Participa do Grupo de Pesquisas Educação, História e Diversidades (Ifes), desenvolvendo pesquisas na área de Educação e Diversidade, analisando e discutindo as políticas e práticas relacionadas a alunos com necessidades educativas especiais, como surdo, cego e deficiência visual, déficit de atenção, autista, altas habilidades, bem como às questões de gênero, raça, cultura, além das políticas anti-homofóbicas. E-mail: thiengo.thiengo@gmail.com.

\section{COLABORADORES}

\section{A}

Allana Resende - Mestranda no Programa de Mestrado Profissional em Educação em Ciências e Matemática no Instituto Federal do Espírito Santo, participa do Grupo de Pesquisas Educação, História e Diversidades (Ifes) desenvolvendo pesquisas na área de Educação e Diversidade, anal- 
isando e discutindo a aprendizagem de alunos com necessidades especiais com base na psicologia histórico-cultural. E-mail: allanacbr@hotmail.com

Ana Paula Brasil - Mestranda no Programa de Pós-graduação em Educação em Ciências e Matemática do Ifes (Educimat). Especialista em Políticas Públicas de Gênero e Raça. Especialista em Nutrição Humana e Saúde. Bióloga. Técnica em Assuntos Educacionais no Instituto Federal de Educação, Ciência e Tecnologia do Espírito Santo campus Linhares. E-mail: anapaulabrasi1.2012@gmail.com

Antônio Lopes de Souza Neto - Servidor técnico-administrativo da Universidade Federal do Espirito Santo (UFES), Especialização em Educação a Distancia pela Universidade Federal de Mato Grosso e graduação em Física-Licenciatura pela Universidade Federal do Espírito Santo, mestre no Programa de Pós-graduação em Educação em Ciências e Matemática do Instituto Federal do Espírito Santo. Atua junto ao movimento social LGBT participando como palestrante e formador em diversos espaços. E-mail: antoniolopes.ifes@gmail.com

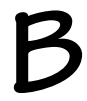

Brenda Odete Pfeifer de Araújo - Possui graduação em Ciências Biológicas pela Universidade Federal do Espírito Santo (2008). É especialista em Educação Ambiental pelo Instituto Superior de Educação e Cultura Ulysses Boyd (2011). É aluna do programa de Mestrado Profissional em Ensino de Ciências e 
Matemática do Instituto Federal do Espírito Santo - Ifes (2015). Atualmente é professora de Biologia da educação básica (ensino médio) e coordenadora escolar - Secretaria da Educação, Governo do Estado do Espírito Santo. Tem experiência na área de Educação (ensino fundamental e médio), com ênfase no ensino de Biologia para o ensino médio; e em Zoologia, com ênfase em taxonomia de vespas parasitoides. E-mail: brendabio@hotmail.com

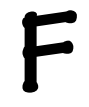

Flávio Lopes dos Santos - Mestre em Educação Matemática pelo Ifes - Instituto Federal do Espírito Santo, Graduado em Ciência da Computação pela FAESA - Faculdades Integradas Espírito-santense (2014), Especialista em Administração de Sistemas de informação pela UFLA - Universidade Federal de Lavras (2007), Pós-graduado em Direito Público pela FADIVALE - Faculdade de Direito do Vale do Rio Doce (2004), Bacharel em Direito pela FADIVALE (2001). E-mail: flaviolopesgv@gmail.com

\section{G}

Guilherme Augusto Maciel Ribeiro - Mestrando pelo Programa de Pós-graduação em Educação em Ciências e Matemática no Instituto Federal do Espírito Santo - Campus Vitória (ES). Graduado em Licenciatura Plena em Ciências Biológicas pelo Centro Universitário São Camilo - Campus Espírito Santo. Especialização Lato Sensu em Docência do Ensino Superior pela 
Faculdade de Educação da Serra. Especialista em Gestão da Educação, com habilitação em Administração, Supervisão, Inspeção, Coordenação e Orientação Educacional pela Faculdade de Nanuque (MG). Especialização em Educação e Gestão Ambiental pela Faculdade de Tecnologia de Cachoeiro de Itapemirim (ES). Professor Estatutário de Ciências na Educação Básica pela Prefeitura Municipal de Marataízes. Possui experiência na docência de Ciências Naturais e Biologia na Educação Básica e no Nível Superior, além de atuar em Programas Municipais de Formação Continuada para professores da Educação Básica. Desenvolve pesquisas voltadas para Estratégias Metodológicas para o ensino de Ciências Naturais e Biologia em ambientes formais e não formais, além de promover investigações acadêmicas sobre Gênero e Sexualidade na Educação. E-mail: gamribeiro@gmail.com

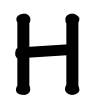

Haroldo Junior Evangelista Vidal - É professor do curso de Rádio e TV - do Centro Estadual de Educação Técnica Vasco Coutinho (SECTTI). Possui Graduação em Rádio e TV pela Faculdades Integradas Espírito Santenses (FAESA) 2008, Licenciatura em Letras Português e Literatura pelo Centro Universitário São Camilo (CUSC) 2009, e Licenciatura em Pedagogia pela Faculdade de Ciências de Wenceslau Braz (FACIBRA) 2015. Pós graduado em Gestão Educacional pela Faculdade de Educação de Vitória 2010 e Comunicação e Marketing pela Universidade Candio Mendes (RJ) 2011 e Mestre em Gestão Social e Educação pela Faculdade Vale do Cricaré (FVC) 2014. Atuou como 
produtor de TV na TV Vitória Rede Record no ES e como programador musical e produtor na Rádio Espírito Santo. Foi assistente de promoção na Rede Gazeta, filiada Rede Globo. Professor do curso de comunicação social da Faculdade Estácio de Sá de Vitória (FESV). Atualmente é professor dos cursos de Psicologia e Pedagogia da Associação Vitoriana de Ensino Superior (FAVI). Professor coordenador e orientador da TV CEET (Canal Universitário/ES - Canal 13 NET). E-mail: haroldovidal@hotmail.com

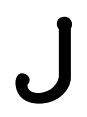

Janivaldo Pacheco Cordeiro - Licenciado em Matemática pela Universidade do Estado da Bahia (2005), Professor Efetivo da Rede Estadual de Ensino do Espírito Santo, Mestre do Programa em Educação, Ciências e Matemática pelo Ifes - Instituto Federal do Espírito Santo. E-mail: janivaldocordeiro@gmail.com.

\section{$\mathrm{N}$}

Nahun Thiaghor Lippaus Pires Gonçalves - Professor de Química; Mestre em Biotecnologia pela Universidade Federal do Espírito Santo (UFES); Mestre em Educação em Ciência e Matemática pelo Instituto Federal do Espírito Santo (Ifes); Especialista em Educação de Jovens e Adultos; Artes e Educação, ambas pela Faculdade de Estudos Sociais Aplicados de Viana (FESAV); 
Especializado em Farmacologia Básica e Clínica (UFES); Graduado em Farmácia (UVV); Serviço Social (UFES); Pedagogia (FASE); Licenciando em Química (Ifes), Integra o grupo Fopec. E-mail: nahunthiaghor@gmail.com

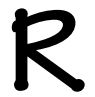

Robson Vinicius Cordeiro - Professor de Filosofia na Rede Municipal de Ensino de Cariacica-ES. Licenciado em Filosofia pela Faculdade Salesiana de Vitória (2009) e especialista em Arte-Educação pela Faculdade de Educação Regional Serrana (2011). Mestre do Programa de Pós-Graduação em Educação em Ciências e Matemática pelo Instituto Federal do Espírito Santo (EDUCIMAT/Ifes). E-mail:cordeirorobson@hotmail.com.

Robson Wilson Carneiro Onofre - possui graduação em Química pela Universidade Federal do Espírito Santo (2007) e especialização em "Metodologia de Ensino de Química" pela Universidade Gama Filho (2009) . Atualmente é Professor da Secretaria de Educação do Estado do Espírito Santo. Tem experiência na área de Educação. Atuando principalmente nos seguintes temas: Sexualidade trans, Ciências, Inclusão, Cotidiano. E-mail: robsononofre@ig.com.br

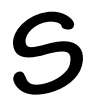

Steferson Zanoni Roseiro - Graduado em Pedagogia pela Ufes, bolsista de iniciação científica e membro do Grupo de Pesquisa em Sexualidades (Gepss/Ufes). E-mail: zanoniroseiro@hotmail.com 


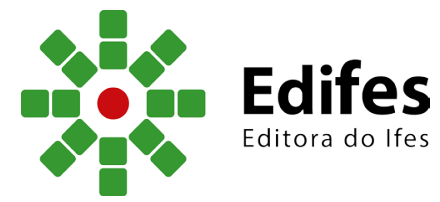

164 
Um grupo de educadores, atentos às desigualdades sociais e ao desrespeito às diferenças existentes hoje na sociedade, reuniu-se para dialogar e debater temas que foram surgindo em função de demandas, formando-se assim o grupo de pesquisa Educação Matemática \& Diversidades.

Esta obra, tecida no interior deste grupo de estudos, apresenta importante material que coloca em destaque algumas das questões que foram objeto de discussões, e compartilha com os leitores resultados iniciais de tais discussões. Cada artigo é resultado do esforço de um pesquisador, e o leitor poderá perceber um pouco de cada um, seus olhares e vivências, bem como a preocupação em colaborar com o debate proposto.

\section{Edmar Reis Thiengo}

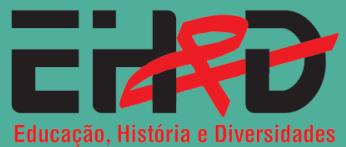

Educação, História e Diversidades

Instituto Federal do Espirito Santo

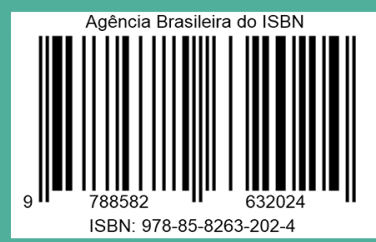

